\title{
Vervolgopleidingen op eigen initiatief en investering door politiemensen: welke prikkels dragen hieraan bij?
}

Citation for published version (APA):

Gerards, R., Künn-Nelen, A. C., \& Verhagen, A. M. C. (2013). Vervolgopleidingen op eigen initiatief en investering door politiemensen: welke prikkels dragen hieraan bij? ROA. ROA Reports No. 009 https://doi.org/10.26481/umarep.2013009

Document status and date:

Published: 01/01/2013

DOI:

10.26481/umarep.2013009

Document Version:

Publisher's PDF, also known as Version of record

Please check the document version of this publication:

- A submitted manuscript is the version of the article upon submission and before peer-review. There can be important differences between the submitted version and the official published version of record.

People interested in the research are advised to contact the author for the final version of the publication, or visit the DOI to the publisher's website.

- The final author version and the galley proof are versions of the publication after peer review.

- The final published version features the final layout of the paper including the volume, issue and page numbers.

Link to publication

\footnotetext{
General rights rights.

- You may freely distribute the URL identifying the publication in the public portal. please follow below link for the End User Agreement:

www.umlib.nl/taverne-license

Take down policy

If you believe that this document breaches copyright please contact us at:

repository@maastrichtuniversity.nl

providing details and we will investigate your claim.
}

Copyright and moral rights for the publications made accessible in the public portal are retained by the authors and/or other copyright owners and it is a condition of accessing publications that users recognise and abide by the legal requirements associated with these

- Users may download and print one copy of any publication from the public portal for the purpose of private study or research.

- You may not further distribute the material or use it for any profit-making activity or commercial gain

If the publication is distributed under the terms of Article 25fa of the Dutch Copyright Act, indicated by the "Taverne" license above, 


\section{Vervolgopleidingen op eigen initiatief en investering door politiemensen: welke prikkels dragen hieraan bij?}

Ruud Gerards

Annemarie Künn-Nelen

Annelore Verhagen

ROA-R-2013/9 


\section{Colofon}

(C) Researchcentrum voor Onderwijs en Arbeidsmarkt (ROA). Niets uit deze uitgave mag op enige manier worden verveelvoudigd zonder voorafgaande schriftelijke toestemming van de directeur van het ROA.

\section{Researchcentrum voor Onderwijs en Arbeidsmarkt}

School of Business and Economics

Maastricht University

\section{Vormgeving}

ROA secretariaat, Maastricht

\section{Verkoop}

Researchcentrum voor Onderwijs en Arbeidsmarkt email: secretary-roa-sbe@maastrichtuniversity.nl website: www.roa.nl

ISBN: 978-90-532I-516-6 


\section{Inhoud}

Voorwoord $\quad$ v

Samenvatting en conclusies vii

$\begin{array}{lll}1 & \text { Inleiding } & 17\end{array}$

$\begin{array}{ll}1.1 \text { Onderzoeksvraag } & 18\end{array}$

$\begin{array}{ll}1.2 \text { Onderzoeksaanpak } & 19\end{array}$

$\begin{array}{lll}1.3 & \text { Opzet rapport } & 21\end{array}$

2 Huidige stand van zaken met betrekking tot politieonderwijs 23

2.1 Inleiding 24

2.2 Het aanbod van politieonderwijs 24

2.3 Huidig opleidings- en trainingsbeleid 26

3 Opleidingsdeelname tot nu toe 33

$\begin{array}{ll}3.1 \text { Inleiding } & 34\end{array}$

3.2 Opleidingsdeelname in de afgelopen drie jaar 34

3.3 Wie heeft de afgelopen drie jaar aan een vervolgopleiding deelgenomen? 36

3.4 Redenen voor het volgen van vervolgopleidingen 41

3.5 (Gedeeltelijke) zelfmelders en niet-zelfmelders 46

4 Verwachte deelname aan vervolgopleidingen en bereidheid tot eigen initiatief, eigen betaling en leren in eigen tijd 53

4.1 Inleiding 54

4.2 Wie wil de komende jaren aan een vervolgopleiding deelnemen? $\quad 54$

4.3 In welke vervolgopleiding hebben politiemensen interesse? 61

4.4 Waarom willen politiemensen zich verder ontwikkelen? 65

4.5 Eigen bereidheid aangaande een vervolgopleiding in de toekomst 67 
$5 \quad$ Prikkels voor het volgen van een vervolgopleiding 71

$\begin{array}{ll}5.1 \text { Inleiding } & 72\end{array}$

5.2 Waarom is een deel van de politiemensen niet van plan een vervolgopleiding te gaan volgen? 72

5.3 Hoe kunnen politiemensen die niet van plan zijn een vervolgopleiding te gaan volgen gestimuleerd worden dit wel te doen? 74

5.4 Prikkels voor het volgen van een vervolgopleiding 75

6 Prikkels ter vergroting van het aantal zelfmelders 79

$\begin{array}{ll}6.1 \text { Inleiding } & 80\end{array}$

6.2 Een hypothetische situatie... 80

6.3 Prikkels voor het verhogen van de eigen bereidheid bij het volgen van een vervolgopleiding $\quad 85$

$7 \quad$ Belangrijkste bevindingen en slotconclusies $\quad 89$

7.1 Opleidingsdeelname en (gedeeltelijk) zelfmelden tot nu toe 89

7.2 Verwachte toekomstige deelname aan vervolgopleidingen en bereidheid tot eigen initiatief, deelname in eigen tijd en eigen financiële bijdrage 90

7.3 Prikkels voor het volgen van een vervolgopleiding 91

7.4 Prikkels ter vergroting van het aantal zelfmelders 92

7.5 Haalbaarheid van de prikkels 93

$\begin{array}{ll}7.6 \text { Slotconclusies } & 95\end{array}$

Bijlage A: De steekproef 99

Bijlage B: De invloed van persoonlijkheidskenmerken op zelfmelden bij de laatst gevolgde vervolgopleiding

Bijlage C: Persoonlijkheidskenmerken en de verwachte toekomstige deelname aan vervolgopleidingen

Bijlage D: Gesprekspartners

Bijlage E: Itemlijst interviews $\quad 113$

$\begin{array}{ll}\text { Bijlage F: Itemlijst focusgroep } & 117\end{array}$

$\begin{array}{ll}\text { Summary } & 119\end{array}$ 


\section{Voorwoord}

Het is bij de politie tot op heden gebruikelijk dat politiemensen door hun leidinggevende worden aangemeld voor het volgen van een opleiding bij de Politieacademie, dat de werkgever de opleiding betaalt en de opleiding plaatsvindt onder werktijd. Vanuit overleg tussen de directeur Politie en de politievakbonden eind 2oII is de behoefte kenbaar geworden om tot meer 'zelfmelders' te komen. Hierbij zijn 'zelfmelders' politiemensen, die (deels) op eigen initiatief en met (gedeeltelijke) inzet van eigen tijd en/of geld een vervolgopleiding gaan volgen.

Het Researchcentrum voor Onderwijs en Arbeidsmarkt (ROA) van de Universiteit Maastricht heeft in opdracht van het Wetenschappelijk Onderzoek- en Documentatiecentrum (WODC) van het Ministerie van Veiligheid en Justitie, onderzoek gedaan naar de factoren die politiemensen kunnen bewegen om als 'zelfmelder' aan een vervolgopleiding deel te nemen. Voor de uitvoering van dit onderzoek hebben wij gebruik gemaakt van een combinatie van kwantitatief en kwalitatief onderzoek, te weten: een literatuurstudie, interviews met betrokkenen bij het politieonderwijs, interviews met politiemensen, een enquête onder politiemensen, interviews met ervaringsdeskundigen op het gebied van onderwijs in sectoren buiten de politie en een focusgroep met betrokkenen.

Wij willen alle gesprekspartners van de interviews en de focusgroep bedanken voor hun medewerking. In bijlage $\mathrm{D}$ zijn alle gesprekspartners met hun toestemming bij naam vermeld. Tevens willen wij alle politiemedewerkers bedanken die de enquête hebben ingevuld. Een speciaal woord van dank gaat uit naar de voorzitter en de leden van de begeleidingscommissie, die ons tijdens het onderzoek begeleid hebben en van advies hebben voorzien. 
Begeleidingscommissie

Voorzitter:

Dhr. prof. dr. S. Karsten (Sjoerd)

Universiteit van Amsterdam, Faculteit der Maatschappij- en Gedragswetenschappen

Leden:

Dhr. dr. G. Haverkamp (Gerrit)

Ministerie van Veiligheid en Justitie, WODC

Mevr. drs. M.J.M. Janssen (Marga)

Ministerie van Veiligheid en Justitie, DG Politie

Mevr. drs. K. Jettinghoff (Karin)

Centrum voor Arbeidsverhoudingen

Mevr. drs. O.E. Kramers (Olivia) en Overheidspersoneel (CAOP)

Mevr. prof. dr. M.A.C.T. Kuijpers (Marinka) Open Universiteit, Onderwijswetenschappen

Dhr. dr. J.B.A. Prins (Jan)

Politieacademie 


\section{Samenvatting en conclusies}

Tot op heden is het binnen de politie gebruikelijk dat politiemensen door hun leidinggevende worden aangemeld voor het volgen van een opleiding bij de Politieacademie, dat de werkgever de opleiding betaalt en de opleiding plaatsvindt onder werktijd. Hierdoor is het vrijwel uitgesloten dat een politiemedewerker op eigen initiatief en met eigen investering in tijd en of geld (als 'zelfmelder') een opleiding aan de Politieacademie gaat volgen. Vanuit overleg tussen de directeur Politie en de politievakbonden eind $201 \mathrm{I}$ is echter de behoefte kenbaar gemaakt om tot meer 'zelfmelders' te komen. Hierbij zijn 'zelfmelders' politiemensen, die (deels) op eigen initiatief en/of met (gedeeltelijke) inzet van eigen tijd en/of geld een vervolgopleiding gaan volgen. Omdat er tot op heden weinig ruimte was voor zelfmelders, is niet bekend welke factoren politiemensen zouden kunnen bewegen om als 'zelfmelder' aan een vervolgopleiding deel te nemen. Ook is niet bekend hoe flexibilisering van het politieonderwijs, gedefinieerd als het aanbieden van variaties in organisatie en vormgeving van het onderwijs, een rol kan spelen om tot meer zelfmelders te komen. Dit leidt tot de volgende onderzoeksvraag:

Hoe kunnen politiemensen gestimuleerd c.q. gefaciliteerd worden, om in de toekomst meer als zelfmelder - op (deels) eigen initiatief, met (gedeeltelijke) inzet van eigen tijd enlof geld - een vervolgopleiding te volgen, en kan flexibilisering van het politieonderwijs daar een rol in spelen?

In deze samenvatting worden de belangrijkste bevindingen van het onderzoek samengebracht. Ten eerste beschrijven we de onderzoeksaanpak. Vervolgens gaan we in op de opleidingsdeelname en (gedeeltelijk) zelfmelden tot nu toe binnen de politie. Hierna bespreken we de verwachte deelname aan vervolgopleidingen voor de toekomst en de bereidheid tot zelfmelden. Daarop volgend gaan we in op de prikkels die in het algemeen van invloed zijn op de intentie om aan een vervolgopleiding deel te nemen. Immers, aan een opleiding willen deelnemen is de eerste stap die nog vooraf gaat aan de afweging om als zelfmelder een opleiding te volgen. Vervolgens gaan we in op de prikkels om een vervolgopleiding als zelfmelder te volgen, waarna we de prikkels die positief uit het onderzoek naar voren komen, beschouwen op hun haalbaarheid. We sluiten af met slotconclusies over de bevindingen. 


\section{Onderzoeksaanpak}

Voor dit onderzoek is gebruik gemaakt van een combinatie van kwantitatief en kwalitatief onderzoek, te weten: literatuurstudie, een enquête onder politiemensen, interviews met betrokkenen bij het politieonderwijs, interviews met politiemensen, interviews met ervaringsdeskundigen op het gebied van onderwijs in sectoren buiten de politie en een focusgroep met betrokkenen. De literatuurstudie is uitgevoerd ter kennisvorming en ter ondersteuning van de overige onderzoeksonderdelen. De enquête vormt de hoofdmoot van het onderzoek. Deze is verstuurd naar 2.4II politiemensen waarvan er I.044 de enquête (gedeeltelijk) hebben ingevuld. Het responspercentage van de enquête is daarmee $43 \%$.

Ter voorbereiding op de enquête zijn er in totaal zes semigestructureerde interviews uitgevoerd met twaalf betrokkenen bij het politieonderwijs. Het betrof medewerkers van: het programma HRM en Onderwijs van het Ministerie van Veiligheid en Justitie, de Inspectie VenJ, de Politieacademie, de Politieonderwijsraad (POR), de afdeling HRM van de Nationale Politie en de P\&O afdeling van een regionale eenheid. Tevens zijn drie politiemensen van verschillende regionale eenheden, rangen en functies geïnterviewd. Het doel van deze interviews was inzicht te krijgen in de redenen om wel of niet deel te nemen aan bepaalde opleidingen, en mogelijke prikkels om zelfmelden te stimuleren. Tot slot zijn er in totaal vier interviews afgenomen met externe deskundigen op het gebied van (flexibel) onderwijs vanuit de sectoren zorg, transport, middelbaar onderwijs en hoger onderwijs. Het doel van deze interviews was om lessen uit andere sectoren te trekken, die relevant zijn voor flexibilisering van het onderwijs bij de politie en in het bijzonder voor het stimuleren van zelfmelders.

In mei 2013 is een focusgroep bijeenkomst gehouden. Hierin waren deskundigen van het programma HRM en Onderwijs van het Ministerie van Veiligheid en Justitie, de Politieacademie, een $\mathrm{P} \& \mathrm{O}$ afdeling van een regionale eenheid en het Ministerie van Onderwijs vertegenwoordigd. De focusgroep had als doel om de bevindingen uit het kwantitatieve deel van het onderzoek terug te koppelen aan de betreffende deelnemers, allen deskundigen en direct betrokkenen bij het politieonderwijs, om langs deze weg nadere duiding te geven aan de onderzoeksuitkomsten en om de conclusies aan te scherpen.

\section{Opleidingsdeelname en (gedeeltelijk) zelfmelden tot nu toe}

Binnen de politie wordt veel aan opleiding gedaan. 80\% van de politiemensen die aan het onderzoek meededen heeft de afgelopen drie jaar een al dan niet verplichte opleiding gevolgd voor het werk. Dit is inclusief initiële opleidingen en verplichte opleidingen zoals (periodieke) hercertificeringen. Als we de initiële opleidingen en verplichte opleidingen buiten beschouwing laten en alleen kijken naar werk-gerelateerde vervolgopleidingen zonder een verplicht karakter, dan blijkt dat ruim twee 
derde van de respondenten de afgelopen drie jaar één of meerdere niet-verplichte vervolgopleidingen heeft gevolgd.

Volledige zelfmelders, die deze niet-verplichte vervolgopleiding volledig op eigen initiatief hebben gevolgd en dit volledig in eigen tijd deden en zelf betaald hebben, zijn er daarbij nauwelijks ( $\mathrm{r} \%)$. Het percentage politiemensen dat als gedeeltelijke zelfmelder aan een vervolgopleiding heeft deel genomen is echter niet gering. $84 \%$ van de respondenten geeft aan de meest recent gevolgde vervolgopleiding geheel of gedeeltelijk op eigen initiatief te hebben gevolgd, al dan niet in combinatie met een (gedeeltelijke) eigen inbreng in termen van tijd en/of geld. Het betrof hierbij voornamelijk respondenten die aangaven zelf (mede) het initiatief te hebben genomen voor de vervolgopleiding of deze deels in eigen tijd te hebben gevolgd. Het (mee) betalen aan een opleiding komt zelden voor. Gedeeltelijke zelfmelders kwamen relatief wat vaker voor onder:

- jongere politiemensen

- hogere rangen

- de domeinen leiding, bedrijfsvoering en onderwijs \& kennis/werving \& selectie

- medewerkers die een hoger verantwoordelijkheidsgevoel hebben voor hun eigen kennis, vaardigheden en ontwikkeling

- medewerkers die het leuk vinden om te leren.

\section{Verwachte toekomstige deelname aan vervolgopleidingen en bereidheid tot eigen initiatief, deelname in eigen tijd en eigen financiële bijdrage}

Bijna $70 \%$ van de politiemensen verwacht binnen vijf jaar een vervolgopleiding te gaan volgen. Het betreft met name de relatief jonge politiemensen, politiemensen die de afgelopen drie jaar ook al een vervolgopleiding gevolgd hebben en politiemensen die het leuk vinden om nieuwe dingen te leren. De loopbaanwensen die politiemensen hebben zijn daarbij niet van invloed op de verwachte deelname aan vervolgopleidingen. De loopbaankansen die politiemensen voor zichzelf in het verschiet zien zijn echter wel van invloed op de verwachte deelname aan vervolgopleidingen. Politiemensen die verwachten binnen vijf jaar een baan buiten de politie te hebben of een specialistische functie te gaan vervullen, schatten de kans dat zij de komende vijf jaar een vervolgopleiding gaan volgen gemiddeld hoger in.

Van deze groep politiemensen die verwacht in de komende vijf jaar een vervolgopleiding te gaan volgen, blijken de meesten bereid om zelf het initiatief hiervoor te nemen. Daarentegen zijn de bereidheid tot het (gedeeltelijk) zelf betalen van de opleidingen en de bereidheid de opleiding (deels) buiten werktijd te volgen beperkt tot zeer beperkt. Slechts $3 \%$ van deze groep politiemensen verwacht de komende vijf jaar een vervolgopleiding te gaan volgen en hiervoor volledig het initiatief te nemen, dit volledig in eigen tijd te doen en helemaal zelf te betalen (volledig zelfmelder). 
Desondanks verwacht $95 \%$ van de politiemensen die in de toekomst een opleiding denkt te gaan volgen, dat ze in meer of mindere mate zelf het initiatief zullen nemen, tijd zullen investeren of financieel een bijdrage eraan zullen leveren. Voor eigen initiatief is de bereidheid relatief het grootst, gevolgd door leren in eigen tijd en zelf mee betalen.

\section{Prikkels voor het volgen van een vervolgopleiding}

Om in de toekomst meer politiemensen een opleiding te laten volgen als 'zelfmelder', is het eerst noodzakelijk dat politiemensen an sich een positieve intentie tot opleiding hebben. Immers, als men niet verwacht om een opleiding te volgen, kan men ook geen zelfmelder worden. Voordat we ingaan op de prikkels die het zelfmelden beïnvloeden hebben we daarom eerst gekeken naar de prikkels die de opleidingsbereidheid in het algemeen beïnvloeden. We hebben hierbij onderscheid gemaakt tussen politiemensen die op dit moment niet verwachten om in de nabije toekomst aan een opleiding deel te nemen en politiemensen die dit wel verwachten te doen.

Ruim 30\% van de politiemensen verwacht niet dat ze binnen vijf jaar een vervolgopleiding zullen volgen. Deze groep geeft aan dat hun bereidheid om dit wel te doen vergroot wordt door de volgende prikkels: de vervolgopleiding onder werktijd kunnen volgen, de vervolgopleiding leidt tot een hoger salaris binnen de huidige functie, de vervolgopleiding wordt betaald door de werkgever en een vervolgopleiding naar keuze mogen volgen.

Als we de focus verleggen van de groep die niet verwacht in de toekomst aan een opleiding deel te nemen en we kijken weer naar de gehele groep respondenten, dan vinden we dat er voor politiemensen in het algemeen ook diverse prikkels zijn die deelname aan een vervolgopleiding kunnen stimuleren. Het betreft met name: de vervolgopleiding onder werktijd kunnen volgen, de opleiding tijd- en plaats onafhankelijk kunnen volgen en de opleiding modulair kunnen volgen. De prikkels werken beter op politiemensen die in de laatste drie jaar geen opleiding gevolgd hebben, dan op politiemensen die in de laatste drie jaar wel een vervolgopleiding hebben gevolgd.

Als we hierbij onderscheid maken tussen politiemensen die recentelijk wel of niet een vervolgopleiding hebben gevolgd, dan blijkt dat de prikkels beter lijken te werken op politiemensen die recentelijk géén vervolgopleiding gevolgd hebben. Alle prikkels werken dus relatief minder sterk op politiemensen die wel al recent aan een vervolgopleiding hebben deel genomen. Dit lijkt wellicht enigszins contra-intuïtief maar is het niet. Dat juist deze groep relatief minder op de prikkels reageert, betekent dat ze een hogere intrinsieke motivatie hebben tot het volgen van opleiding en minder extrinsiek geprikkeld hoeven worden. Dit blijkt ook uit het onderzoek. We vonden dat de verwachte toekomstige deelname aan vervolgopleidingen significant groter is onder politiemensen die de afgelopen drie jaar al aan een vervolgopleiding hebben 
deelgenomen. We kunnen hieruit een belangrijke conclusie trekken. Wanneer politiemensen in het recente verleden (laatste drie jaar) een vervolgopleiding hebben gevolgd, is hun intrinsieke motivatie om in de toekomst nog een vervolgopleiding te volgen relatief hoog. Als men eenmaal 'geproefd' heeft aan het leren, is men eerder geneigd nog meer te leren. Dit maakt het belangrijk om juist politiemensen die recentelijk niet aan een vervolgopleiding hebben deel genomen, weer te laten proeven aan het leren. Dat de bovengenoemde prikkels juist voor deze politiemensen relatief het beste lijken te werken is een aangename bevinding.

\section{Prikkels ter vergroting van het aantal zelfmelders}

De twee prikkels die het meeste effect hebben op de bereidheid tot 'zelfmelden' zijn monetair van aard. 'Een hoger salaris' en 'een betaalde opleiding mogen volgen' zijn beide voor een aanzienlijke meerderheid van de respondenten reden om in de toekomst meer bereid te zijn tot zelfmelden. Ook als men onder werktijd een vervolgopleiding mag volgen stijgt de bereidheid om zelf (mee) te betalen en zelf initiatief te nemen bij minimaal de helft van de politiemensen. Het mogen volgen van een vervolgopleiding naar keuze of een garantie op een bij de opleiding passende functie hebben ook positief effect op de bereidheid tot zelfmelden van ongeveer de helft van de respondenten. Het aanbieden van flexibele onderwijsvormen zoals modulair opleiden en tijd- en plaats-onafhankelijk leren werkt relatief minder stimulerend in de bereidheid tot (gedeeltelijk) zelfmelden, maar verhoogt deze bereidheid toch van ongeveer een derde van de respondenten.

De resultaten van het onderzoek tonen dat van de drie facetten van zelfmelden, de bereidheid tot het nemen van eigen initiatief relatief het meest beïnvloedbaar is. Daarentegen lijkt het iets minder gemakkelijk om politiemensen te stimuleren tot het opleiden in eigen tijd. Nog moeilijker wordt het om de bereidheid te beïnvloeden om een eigen financiële bijdrage te leveren aan de kosten van de opleiding.

\section{Haalbaarheid van de prikkels}

De opleiding leidt tot een hoger salaris in huidige functie / de opleiding wordt betaald door de werkgever

Eén van de prikkels die bij de meeste politiemensen de bereidheid tot zelfmelden vergroot is als de opleiding door de werkgever betaald wordt. Echter, deze prikkel staat haaks op een van de drie facetten van zelfmelden die in dit onderzoek verkend worden: het (deels) op eigen kosten een opleiding volgen. Als we daarbij, gebaseerd op de diverse interviews en de focusgroep, van de realiteit uitgaan waarin opleidingsbudgetten onder druk staan, dan lijken monetaire prikkels zoals een door de werkgever betaalde opleiding of een hoger salaris in de huidige functie niet met deze realiteit 
verenigbaar. Dit impliceert dat de implementatie van de prikkels 'meer salaris in de huidige functie' en 'de vervolgopleiding wordt betaald' een onrealistische toename van de financiële middelen binnen de eenheden vereist. De conclusie is daarom op het eerste oog dat deze twee prikkels niet binnen het huidige politiebeleid passen.

Toch stijgt van ruim zestig procent van de geënquêteerde politiemensen de bereidheid om eigen initiatief en/of tijd in een vervolgopleiding te investeren als deze maar door de werkgever betaald wordt. Dit lijkt de mogelijkheid te bieden om zelfmelden in ieder geval flink te stimuleren op de facetten van eigen initiatief en tijd. In feite is dit een uitruilscenario waar men bij een grote zorginstelling in de Randstad al ervaring mee heeft. Daar is men tot de conclusie gekomen dat het voor de organisatie veel kostbaarder is om een medewerker vrij te roosteren voor opleidingen dan om de directe monetaire opleidingskosten te betalen. Om die reden hebben ze ervoor gekozen om vooral in te zetten op het verhogen van de bereidheid van medewerkers om in eigen tijd een opleiding te volgen. Enkel wanneer een medewerker ook duidelijk zelf baat heeft bij een opleiding, wordt ook een financiële bijdrage van de medewerker gevraagd. Het gaat dan om opleidingen waarmee de brede arbeidsmarktmogelijkheden van de medewerker, ook buiten de betreffende zorginstelling, sterk vergroot worden.

\section{De opleiding kan onder werktijd gevolgd worden}

Het volgen van een opleiding onder werktijd is een prikkel die eveneens relatief hoge percentages van de geënquêteerde politiemensen beweegt tot een hogere bereidheid om in de toekomst eigen initiatief te tonen en/of (mee) te betalen aan een vervolgopleiding. Echter, hoewel deze prikkel blijkt te werken ten aanzien van die twee facetten van zelfmelden, behelst deze prikkel juist het omgekeerde van wat in dit onderzoek verkend wordt: dat politiemensen ook meer in eigen tijd vervolgopleidingen gaan volgen. Op zijn best kan met deze prikkel dus een uitruil teweeg worden gebracht waarbij een aanzienlijk deel van de politiemensen wel meer initiatief bereid is te tonen en zelf wil (mee)betalen, maar dan alsnog onder werktijd de vervolgopleiding wil volgen.

\section{Men mag een opleiding naar keuze volgen}

Uit het onderzoek blijkt dat ongeveer de helft van de leidinggevenden aangeeft de afgelopen drie jaar geen enkel opleidingsverzoek te hebben afgewezen. Dit impliceert dat deze leidinggevenden de keuze van hun medewerkers voor de te volgen vervolgopleidingen niet belemmeren, wat positief is voor de prikkel 'men mag een vervolgopleiding naar keuze volgen'. Desalniettemin zou de vereiste toestemming van de leidinggevende(n) op zichzelf het gevoel van keuzevrijheid kunnen belemmeren. De optimale invoering van de prikkel 'keuzevrijheid' zou daarom inhouden dat de tussenkomst van de leidinggevende(n) niet langer vereist is bij de inschrijvingen voor bepaalde vervolgopleidingen. Hiermee is echter nog niet de vraag beantwoord wie 
dan de opleiding betaalt en in wiens tijd deze wordt gevolgd. Echter, de prikkel keuzevrijheid heeft telkens voor ongeveer de helft van de politiemensen een positief effect op de bereidheid om eigen tijd in de opleiding te steken en op bereidheid om eigen geld in de opleiding te investeren. De prikkel 'keuzevrijheid' lijkt daarmee kansrijk om in de toekomst tot meer zelfmelders te komen. Het is dan wel van belang dat de opleiding dermate flexibel wordt aangeboden, dat deze ook in de eigen tijd van de medewerker gevolgd kan worden.

\section{Er wordt een garantie geboden voor een baan passend bij de opleiding}

Uit de interviews is gebleken dat vervolgopleidingen tot op heden niet zelden gekoppeld waren aan een promotie of een functieverandering. Achter de wens om in de toekomst meer politiemensen op eigen initiatief en voor eigen rekening een vervolgopleiding te laten volgen, schuilt echter ook de gedachte dat politiemensen daardoor hun keuzes voor vervolgopleidingen op meer intrinsieke gronden maken. Het wordt steeds minder wenselijk geacht dat de motivatie om aan een vervolgopleiding deel te nemen extrinsiek gedreven is. De prikkel van een garantie op een bij de opleiding passende baan lijkt dan ook niet te passen in de beweging van een rechtspositioneel naar een ontwikkelingsgericht personeelsbeleid.

\section{De opleiding kan modulair gevolgd worden / de opleiding kan tijd/plaats onafhankelijk gevolgd worden}

Uit diverse interviews, bijeenkomsten en de focusgroep met beleidsdeskundigen is gebleken dat de Politieacademie positief staat tegenover het aanbieden van meer modulair onderwijs en de toepassing van e-learning onderwijsvormen. E-learning maakt onderwijs tijd- en plaats onafhankelijk. Daarnaast leggen deze prikkels naar alle waarschijnlijkheid relatief de minste druk op de budgets. Het voorbeeld uit de zorgsector op pagina 76 , toont daarnaast dat medewerkers door toepassing van e-learning voor kenniscomponenten van opleidingen niet vrij geroosterd hoeven te worden. Dit leidt tot minder bezettingsproblemen.

\section{Slotconclusies}

De prikkels die uitgaan van flexibilisering van het politieonderwijs, modulair onderwijs en tijd/plaats onafhankelijk onderwijs, blijken ten opzichte van de andere prikkels relatief weinig politiemensen te bewegen tot een grotere bereidheid tot eigen initiatief of inbreng in tijd of geld. Desondanks moet de potentie van de eerstgenoemde prikkels niet worden onderschat. Het juiste referentiekader is namelijk niet de effectiviteit van de andere hoofdzakelijk extrinsieke monetaire prikkels. Het referentiekader is de bestaande situatie waarin vervolgopleidingen doorgaans worden geïnitieerd en betaald door de werkgever en in werktijd mogen worden gevolgd. Dit is de 'ist' situatie waarin 
het onderzoek heeft plaatsgevonden en waaraan de organisatie en haar medewerkers gewend is. De eerste conclusie luidt:

Politiemensen zijn als gevolg van het bestaande beleid rondom vervolgopleidingen gewend om op extrinsieke gronden aan vervolgopleidingen deel te nemen. De 'soll' situatie, waarin meer politiemensen als (gedeeltelijk) zelfmelder aan opleidingen deelnemen, staat ver af van de situatie waaraan politiemensen en organisatie tot op heden gewend zijn.

Met deze 'ist' situatie als uitgangspunt, is het onwaarschijnlijk dat er nieuwe prikkels bloot te leggen zijn die een grote meerderheid van de politiemensen ineens blijken te motiveren om zelf tijd te gaan steken in een opleiding of te betalen voor een opleiding. Het is in die zin juist een bevestiging van de gewenning aan de huidige situatie, dat de extrinsiek motiverende prikkels die gebaseerd zijn op geld en tijd bij zoveel van de geënquêteerde politiemensen effect sorteren. In dit licht, is de bijzonder positieve en hoopvolle tweede conclusie:

Flexibele onderwijsvormen, zoals meer modulair onderwijs en tijd-en plaats onafhankelijk onderwijs aanbieden, vergroten van maar liefst een derde van de politiemensen de bereidheid om als (gedeeltelijk) zelfmelder in de toekomst een vervolgopleiding te gaan volgen.

Hiermee blijkt dat ondanks gewenning aan het huidige extrinsiek gemotiveerde opleidingsbeleid, toch een aanzienlijk deel van de politiemensen al op de intrinsieke prikkels reageert.

Daarnaast toont het onderzoek aan dat er een uitruil mogelijk is tussen diverse facetten van zelfmelden. Het zou bijzonder ambitieus zijn en gezien de onderzoeksresultaten weinig realistisch, om van een situatie zonder zelfmelders te willen gaan naar een situatie met een groot aantal politiemensen die én volledig het eigen initiatief nemen voor een vervolgopleiding, én deze volledig zelf betalen én volledig in eigen tijd volgen. Het lijkt wel mogelijk om, als eerste stap in deze richting, meer politiemensen bereid te vinden om bijvoorbeeld meer eigen initiatief en tijd in een vervolgopleiding te investeren, als deze wel nog door de werkgever betaald wordt. Ruim $60 \%$ van de politiemensen is dan namelijk bereid om een opleiding in eigen tijd of op eigen initiatief te volgen. Deze uitruil - de opleiding wordt door de werkgever betaald, maar in eigen tijd van de werknemer gevolgd - wordt in de zorg al toegepast, zoals het voorbeeld op pagina 94 toont. De derde conclusie luidt daarom:

Zelfmelden kan bij ruim 60\% van de politiemensen gestimuleerd worden op de facetten 'eigen initiatief' en/of 'eigen tijd', als de politie de opleiding betaalt. Dit kan complementair zijn aan het stimuleren van zelfmelders door middel van modulair en tijd-en plaats onafhankelijk onderwijs. 
Het onderzoek toont dus aan dat er diverse in de realiteit toe te passen prikkels zijn waarmee politiemensen gestimuleerd kunnen worden om in de toekomst als zelfmelder een vervolgopleiding te gaan volgen. De flexibele onderwijsvormen modulair en tijd- en plaats onafhankelijk onderwijs zijn hierbij de twee prikkels die het minste druk op budgets lijken te leggen en daarbij de intrinsieke motivatie van politiemensen aanspreekt.

De leidinggevenden lijken daarbij al in redelijke mate klaar te zijn voor een situatie waarin meer politiemensen eigen initiatief gaan nemen voor het volgen van vervolgopleidingen. Diverse resultaten wijzen daarop. In Hoofdstuk 2 staat dat ongeveer de helft van de leidinggevenden heeft aangegeven de afgelopen drie jaar geen enkel opleidingsverzoek te hebben afgewezen. Als men wel een opleidingsverzoek afwees, was dit meestal om budgettaire redenen en minder vaak om inhoudelijke redenen. Dit duidt op een open houding voor het verzoek van de medewerker. Daarnaast staat in Hoofdstuk 2 dat leidinggevenden van mening zijn dat het initiatief voor de meeste soorten vervolgopleidingen, significant meer aan de kant van de medewerker moet liggen dan bij de leidinggevende. Dit geeft aan dat leidinggevenden al niet meer van mening zijn dat louter zij bepalen wie, wanneer, welke opleiding mag volgen. Toch voelt ongeveer de helft van de medewerkers zich nog onvoldoende gesteund door de leidinggevende als het gaat om loopbaanmogelijkheden en toezeggingen daaromtrent. Dit leidt tot de vierde conclusie:

Al met al lijken de leidinggevenden in redelijke mate de juiste instelling te hebben om met de zelfmelders van de toekomst om te gaan, maar komt dit in de beleving van de medewerkers in de praktijk nog niet volledig uit de verf.

Hoeveel bereidheid tot eigen initiatief en eigen inbreng in tijd en geld in de toekomst ook te bewerkstelligen is onder politiemensen, het zal breed gedragen moeten worden door de leiding. Uit interviews met onderwijsdeskundigen zowel uit de zorg als uit het onderwijs, blijkt dat het daarbij van cruciaal belang is dat concreet en consistent, top-down de insteek uitgedragen én toegepast moet worden, dat training en opleiding iets is waarbij ook medewerkers het initiatief kunnen nemen. 



\section{Inleiding}

Het politievak is een dynamisch vak dat zich aan een continu evoluerende maatschappij moet aanpassen. Voorbeelden hiervan die op dit moment nadrukkelijk in de publieke belangstelling staan zijn de groeiende criminaliteit op internet en in de financiële wereld. Ook situaties waarmee de politie dagelijks op straat te maken krijgt worden als gevolg van maatschappelijke veranderingen steeds complexer. Daarnaast leiden demografische ontwikkelingen zoals de vergrijzing en de ontgroening ertoe dat de politie als werkgever in de toekomst meer moeite moet doen om aan de ene kant jongeren en zij-instromers aan te trekken en te behouden, én aan de andere kant ouder wordende politiemensen inzetbaar te houden en een interessant perspectief te bieden voor latere loopbaanfases., ${ }^{\mathrm{I}, 2,3}$ Ook zijn de denkwijzen over carrière en opleiding van de jongere, over het algemeen hoger opgeleide, generaties instromers op de arbeidsmarkt anders dan vroeger. ${ }^{4}$

Door deze veranderingen in het politievak en de demografische ontwikkelingen wordt de arbeidsmarkt voor politiemensen dynamischer en daarmee veranderen ook de opleidingsbehoeften. Opleidingen spelen een grote rol om ervoor te zorgen dat politiemensen na hun initiële opleiding, voortdurend de benodigde nieuwe kennis en vaardigheden opdoen voor zowel hun actuele vakmatige ontwikkeling als voor hun loopbaanontwikkeling. Tot op heden worden deze nieuwe kennis en vaardigheden voor het overgrote deel via het postinitieel onderwijs aan de Politieacademie opgedaan. De Politieacademie is in principe de enige aanbieder van postinitieel politieonderwijs en is als zodanig het instituut waarbij de veranderende opleidingsbehoeften vanuit de politieorganisatie terecht komen.

In het verleden hebben de veranderende opleidingsbehoeften vanuit de politieorganisatie al een beweging op gang gebracht naar meer flexibiliteit in het politieonderwijs. De Inspectie Veiligheid en Justitie (IVenJ) constateerde al in 2007 en wederom in $201 \mathrm{I}$ dat politiemensen vaker losse modules (specifieke kernopgaven) volgen dan complete

I. Cörvers, F. (20I2), 'Relevantie van onzekerheden op de externe arbeidsmarkt voor de strategische personeelsplanning van de nationale politie', paper voor het project Het Politievak in $2020-2024$, Ministerie van BZK, Den Haag.

2. Ekamper P, Horstman R en Huisman C (2005). De veroudering van de personeelssamenstelling van de Nederlandse politie in de periode 2005-20I5. Nederlands Interdisciplinair Demografisch Instituut.

3. Opstelten, I.W. (2013), 'Aanbieding jaarverslag NP - toezegging inzetbaarheid', kenmerk 369276, I5 mei 2013, MinVenJ, Den Haag.

4. Breugel van G. en Cörvers, F. (20I0), Arbeidspotentieel voor de politie, nu en in de toekomst, Maastricht. 
leergangen.5 De minister van Veiligheid en Justitie heeft aanbevolen op deze trend in te spelen door de Politieacademie meer modulair en flexibel onderwijs te laten aanbieden. ${ }^{6}$ Ook van de politiemensen zelf wordt in de toekomst in toenemende mate verwacht dat zij actief en continu werken aan het bijhouden van hun vakmanschap. Een leven lang leren is het devies. ${ }^{7}$

Het is tot heden gebruikelijk dat politiemensen door hun leidinggevende worden aangemeld voor het volgen van een opleiding bij de Politieacademie, dat de werkgever de opleiding betaalt en dat de opleiding plaatsvindt onder werktijd. Hierdoor is het vrijwel uitgesloten dat een politiemedewerker op eigen initiatief en met eigen investering in tijd en of geld (als 'zelfmelder') een opleiding aan de Politieacademie kan volgen.

Vanuit overleg tussen de directeur Politie en de politievakbonden eind 20II is echter de behoefte kenbaar gemaakt om tot meer 'zelfmelders' te komen. Hierbij zijn 'zelfmelders' politiemensen, die (deels) op eigen initiatief en met (gedeeltelijke) inzet van eigen tijd en/of geld een vervolgopleiding gaan volgen.

\subsection{Onderzoeksvraag}

Omdat er tot op heden weinig ruimte was voor zelfmelders, is niet bekend welke factoren politiemensen zouden kunnen bewegen om als 'zelfmelder' aan een vervolgopleiding deel te nemen. Ook is niet bekend hoe flexibilisering van het politieonderwijs, gedefinieerd als het aanbieden van variaties in organisatie en vormgeving van het onderwijs, een rol kan spelen om tot meer zelfmelders te komen. Dit leidt tot de volgende onderzoeksvraag:

Hoe kunnen politiemensen gestimuleerd c.q. gefaciliteerd worden, om in de toekomst meer als zelfmelder - op (deels) eigen initiatief, met (gedeeltelijke) inzet van eigen tijd enlof geld - een vervolgopleiding te volgen, en kan flexibilisering van het politieonderwijs daar een rol in spelen?

Voor het beantwoorden van deze onderzoeksvraag zal in de Hoofdstukken 2 tot en met 6 van dit rapport achtereenvolgens in worden gegaan op de volgende onderwerpen:

5. Inspectie Openbare Orde en Veiligheid, Staat van het Nederlandse politieonderwijs 2007 en 20II, Den Haag april 2007 en juni 2012.

6. Minister van Veiligheid en Justitie, Aanbiedingsbrief Staat van het Nederlandse Politieonderwijs 2011 en de Summatieve evaluatie PO2002, 5 juli 20I2, kenmerk 268910, Den Haag juli 2012.

7. Vellinga A, Politieonderwijs anno nu, Apeldoorn $20 \mathrm{I2}$. 
- De huidige stand van zaken met betrekking tot het politieonderwijs

- De opleidingsdeelname van politiemensen tot nu toe

- De verwachte deelname aan vervolgopleidingen en de bereidheid tot eigen initiatief en eigen investering in tijd en geld

- De prikkels voor het volgen van een vervolgopleiding

- De prikkels voor het volgen van een vervolgopleiding als zelfmelder.

Bij de behandeling van deze onderwerpen zal onderscheid worden gemaakt naar diverse persoonlijke en werk-gerelateerde kenmerken van politiemensen zoals leeftijd, geslacht, rang, domein en diverse persoonlijkheidskenmerken zoals risicovoorkeur en leergierigheid.

\subsection{Onderzoeksaanpak}

Voor dit onderzoek is gebruik gemaakt van een combinatie van kwantitatief en kwalitatief onderzoek, te weten: literatuurstudie, een enquête onder politiemensen, interviews met betrokkenen bij het politieonderwijs, interviews met politiemensen, interviews met ervaringsdeskundigen op het gebied van onderwijs in sectoren buiten de politie en een focusgroep met betrokkenen.

\section{Literatuurstudie}

Tijdens de literatuurstudie zijn beleidsdocumenten en wetenschappelijke studies geraadpleegd. Het betrof onder meer rapporten en andere documenten van de Politieacademie, het Ministerie van Veiligheid en Justitie en van de Nationale Politie. De literatuurstudie diende naast het helpen beantwoorden van de onderzoeksvraag tevens ter voorbereiding en ondersteuning voor de andere onderdelen van het onderzoek.

\section{Enquête}

De hoofdmoot van het onderzoek bestaat uit een enquête onder politiemensen die in maart 2013 is afgenomen via het Flitspanel van het Ministerie van Binnenlandse Zaken en Koninkrijksrelaties. Het doel van de enquête was om een kwantitatief beeld te krijgen van de ervaringen, wensen en prikkels van politiemensen ten aanzien van opleidingen, al dan niet als zelfmelder. In de enquête is onderscheid gemaakt tussen leidinggevenden en niet-leidinggevenden. Dit maakte het mogelijk een beeld te krijgen van het personeelsbeleid van leidinggevenden binnen de politie en specifiek van hun ervaringen omtrent opleidingsvragen van medewerkers. Dit beeld wordt in het rapport gecontrasteerd met de beleving van medewerkers. 
Bij het opstellen van de enquête is gebruik gemaakt van resultaten uit de literatuurstudie en de kwalitatieve interviews alsmede van de input vanuit de begeleidingscommissie van het onderzoek.

De enquête is verstuurd naar 2.4II politiemensen waarvan er I.044 de enquête (gedeeltelijk) hebben ingevuld. Het responspercentage van de enquête is daarmee $43 \%$. In Bijlage A is een overzicht gegeven van de representativiteit van deze steekproef.

\section{Interviews}

Naast de enquête zijn er in totaal zes semigestructureerde interviews uitgevoerd met twaalf betrokkenen bij het politieonderwijs. Het betrof medewerkers van: het programma HRM en Onderwijs van het Ministerie van Veiligheid en Justitie, de Inspectie VenJ, de Politieacademie, de Politieonderwijsraad (POR), de afdeling HRM van de Nationale Politie en de P\&O afdeling van een eenheid. In de gesprekken is ingegaan op de achtergrond van de flexibilisering van het politieonderwijs, de ervaringen die men tot nu toe heeft met flexibilisering van het politieonderwijs, de verwachtingen die men heeft bij verdere flexibilisering van het postinitiële politieonderwijs en de mogelijkheden en belemmeringen van het flexibiliseren van het postinitiële politieonderwijs.

Daarnaast zijn drie politiemensen van verschillende regionale eenheden, rangen en functies geïnterviewd. Het doel van deze interviews was inzicht te krijgen in de redenen om wel of niet deel te nemen aan bepaalde opleidingen, en mogelijke prikkels om zelfmelden te stimuleren. Ook deze interviews zijn afgenomen op basis van een semigestructureerde gespreksleidraad.

Tot slot zijn er in totaal vier interviews afgenomen met externe deskundigen op het gebied van (flexibel) onderwijs vanuit de sectoren zorg, transport, middelbaar onderwijs en hoger onderwijs. In deze gesprekken is ingegaan op hun ervaringen met flexibilisering van onderwijs en het stimuleren van zelfmelden. Het doel van deze interviews was om lessen uit andere sectoren te trekken, die relevant zijn voor flexibilisering van het onderwijs bij de politie en in het bijzonder voor het stimuleren van meer zelfmelders.

\section{Focusgroepen}

Tot slot is er in mei 2013 een focusgroep bijeenkomst gehouden. Deze focusgroep bestond uit vijf personen plus een gespreksleider. Hierin waren deskundigen van het programma HRM en Onderwijs van het Ministerie van Veiligheid en Justitie, de Politieacademie, een $\mathrm{P} \& \mathrm{O}$ afdeling van een regionale eenheid en het Ministerie van Onderwijs vertegenwoordigd. De focusgroep had als doel om de bevindingen uit het kwantitatieve deel van het onderzoek terug te koppelen aan de betreffende deelnemers 
en om langs deze weg nadere duiding te geven aan de onderzoeksuitkomsten en om de conclusies aan te scherpen.

\subsection{Opzet rapport}

In dit rapport gaan wij in op de belangrijkste uitkomsten van het onderzoek, waarbij de resultaten uit de kwalitatieve gesprekken en de focusgroep niet in aparte hoofdstukken besproken worden, maar aangehaald worden wanneer de uitkomsten van het kwantitatief onderzoek daar aanleiding voor geven.

De Hoofdstukken 2 en 3 zijn beschrijvende hoofdstukken en gaan eerst in op de huidige stand van zaken met betrekking tot het politieonderwijs (Hoofdstuk 2). Vervolgens gaat Hoofdstuk 3 in op de opleidingsdeelname tot nu toe en de mate waarin politiemensen in het verleden (gedeeltelijk) als zelfmelder een opleiding hebben gevolgd. In Hoofdstuk 4 wordt de verwachte deelname aan vervolgopleidingen in de komende vijf jaar besproken, alsmede de bereidheid tot eigen initiatief en eigen investeringen in termen van tijd en geld. Hoofdstuk 5 gaat in op prikkels voor het volgen van een vervolgopleiding. Immers, aan een vervolgopleiding willen deelnemen is de eerste stap, die nog vooraf gaat aan de afweging om als zelfmelder een opleiding te volgen. In Hoofdstuk 6 worden de prikkels besproken die specifiek van toepassing zijn op het volgen van een vervolgopleiding als zelfmelder. Hoofdstuk 7 vat samen en concludeert. 



\section{Huidige stand van zaken met betrekking tot politieonderwijs}

$\mathrm{Na}$ afronding van de initiële basisopleiding kunnen of moeten politiemensen postinitiële opleidingen (vervolgopleidingen) volgen. De helft van de leidinggevenden heeft de afgelopen drie jaar één of meerdere vervolgopleidingsverzoeken afgewezen. De vaakst genoemde reden voor het afwijzen van deze vervolgopleidingsverzoeken is dat er niet voldoende opleidingsbudget beschikbaar was. Ruim twee derde van de leidinggevenden heeft 'bevorderen van inzetbaarheid van medewerkers' als een van de belangrijkste speerpunten. Meer dan de helft van alle respondenten werkt in een team waar er via jaargesprekken, werkoverleg, regelmatige feedback van collega's en/of regelmatige feedback van de leidinggevende aandacht wordt besteed aan hun functioneren en/of hun loopbaanontwikkeling. Leidinggevenden lijken uit te gaan van gezamenlijkheid van initiatief bij te volgen vervolgopleidingen. Over het algemeen lijken medewerkers tevreden met de hoeveelheid waardering, steun, advies en feedback die ze van hun leidinggevende(n) ontvangen. Daarentegen geeft ongeveer de helft aan dat ze zich niet voldoende gesteund voelt door de leidinggevende(n) met betrekking tot loopbaanmogelijkheden of dat toezeggingen met betrekking tot hun loopbaanontwikkeling niet altijd worden nagekomen. 


\section{$2.1 \quad$ Inleiding}

Dit hoofdstuk geeft een beeld van de huidige stand van zaken met betrekking tot het politieonderwijs. Paragraaf 2.2 beschrijft het huidige aanbod van politieopleidingen in een voor het onderzoek relevante typologie. Paragraaf 2.3 kijkt vervolgens naar het huidige opleidings- en trainingsbeleid binnen de politieorganisatie.

\subsection{Het aanbod van politieonderwijs}

Het aanbod van politieonderwijs bestaat uit initiële en postinitiële opleidingen. Initiële opleidingen mogen vanwege het geweldsmonopolie van de politie alleen door de Politieacademie worden gegeven en zijn bedoeld als basisopleiding voor mensen die starten met een baan bij de politie. Er zijn verschillende niveaus waarop kan worden ingestroomd in het initiële politieonderwijs. De laagste drie niveaus (niveau 2, 3 en 4) zijn vergelijkbaar met het niveau van reguliere $\mathrm{MBO}$ opleidingen. Het niveau van de initiële politieopleidingen op niveau 5 en 6 is vergelijkbaar met het niveau van reguliere $\mathrm{HBO}$ en WO opleidingen. ${ }^{8}$ Daarnaast is het sinds 2006 mogelijk om diverse master opleidingen te volgen waaronder de masters tot: recherchekundige, tactisch leidinggevende, strategisch leidinggevende en criminal and public order management (MCPM). ${ }^{9}$ De grootste instroom in het politieonderwijs is op niveaus 3 en 4 ( $36 \%$, respectievelijk $38 \%$ van de totale instroom). ${ }^{\text {Io }}$

In de Wet op het Landelijk Selectie- en Opleidingsinstituut Politie (LSOP) en het politieonderwijs is vastgelegd dat politieonderwijs gecombineerd moet worden met een praktisch opleidingsdeel, welke ten minste $40 \%$ van de studielast moet behelzen. ${ }^{\text {II }}$ Hierdoor hebben alle initiële studenten een aanstelling bij de politie als aspirant. $\mathrm{Na}$ afronding van de initiële basisopleiding zijn de afgestudeerde aspiranten bevoegd politietaken uit te oefenen op de volgende niveaus, met bijbehorende rangen: $:^{12,13}$

- Assistent politiemedewerker (niveau 2), met als rang politiesurveillant

- Politiemedewerker (niveau 3), met als rang agent

- Allround politiemedewerker (niveau 4), met als rang hoofdagent

- Politiekundige (niveau 5), doorgaans met als rang brigadier maar dit is niet uniform geregeld

- Politiekundige (niveau 6), doorgaans met als rang inspecteur maar ook dit is niet uniform geregeld

- Recherchekundige, tactisch leidinggevende, strategisch leidinggevende, criminal and public order management (niveau 7 / post-HBO).

8. Wet op LSOP en politieonderwijs, artikel I3, lid 2.

9. ACP politievakbond (2013) Politieonderwijs: http://www.acp.nl/studenten/collectief/politieonderwijs/

IO. POR (20I0) Bijdragen aan blauw vakmanschap. Bronnenboek, p.5o.

II. Wet op LSOP en politieonderwijs, artikel I3, lid 8.

I2. Wet op LSOP en politieonderwijs, artikel $\mathrm{I}_{3}$, lid 3.

13. ACP politievakbond (20I3) Politieonderwijs: http://www.acp.nl/studenten/collectief/politieonderwijs/ 
Brigadiers zijn beginnend leidinggevenden, waardoor dit over het algemeen als een doorgroeifunctie wordt gezien. Boven de inspecteur zijn er nog de rangen hoofdinspecteur, commissaris, hoofdcommissaris en eerste hoofdcommissaris (korpschef Nationale Politie).

Nadat de aspiranten hun initiële opleiding hebben afgerond kunnen verschillende soorten postinitieel onderwijs worden gevolgd. Het merendeel van deze opleidingen vallen onder de categorie 'need to have' en worden derhalve aangeboden door de Politieacademie, hoewel de Politieacademie niet altijd de enige gelegitimeerde aanbieder is. Postinitiële opleidingen die door de Politieacademie worden aangeboden zijn nascholingen en her-certificeringen, functiegerichte applicaties ${ }^{14}$, initiële opleidingen ten behoeve van doorstroom en specialistische opleidingen. Daarnaast is het mogelijk om bij- of nascholingen buiten de Politieacademie te volgen.

Een deel van de postinitiële opleidingen heeft een verplicht karakter vanwege (juridisch) verplichte nascholingen en her-certificeringen. Het gaat hierbij bijvoorbeeld om schietvaardigheden of rijvaardigheden, die alle executieve politiemensen dienen bij te houden.

Voor het uitvoeren van bepaalde specifieke handelingen moeten op grond van weten regelgeving certificaten zijn behaald om de bekwaamheid aan te tonen; de zogenaamde voorbehouden handelingen. ${ }^{\text {Is }}$ Functiegerichte applicaties zijn kernopgaven binnen het politieonderwijs, die de deelnemers kwalificeren (certificeren) voor het uitvoeren van voorbehouden handelingen. ${ }^{16}$ Functiegerichte applicaties kunnen zowel verplicht of niet-verplicht van aard zijn. In het onderzoek wordt enkel ingegaan op de niet-verplichte functiegerichte applicaties.

Andere niet-verplichte postinitiële opleidingen zijn ten eerste de initiële opleidingen ten behoeve van doorstroom. Deze opleidingen zijn bedoeld voor politiemensen die een initiële opleiding op een hoger niveau dan het eigen instroomniveau willen volgen en zijn derhalve per definitie alleen op niveau 3 of hoger te volgen. Ten tweede zijn er de specialistische opleidingen op het gebied van handhaving, opsporing, crisisbeheersing, intake \& service en noodhulp. Deze specialistische opleidingen zijn op alle niveaus te volgen. Verder zijn er leidinggevende opleidingen, die enkel op niveau 4 of hoger kunnen worden gevolgd. ${ }^{17}$ Tot slot kunnen opleidingen en bij-of nascholingen buiten de Politieacademie worden gevolgd. Hierbij kan gedacht worden aan de (volledige) reguliere opleiding Bedrijfskunde of Criminologie, maar ook aan werk-gerelateerde bij- of

I4. Zie pagina 8 voor een definitie van functiegerichte applicaties.

15. De politie kent momenteel 299 'voorbehouden handelingen' waarvoor op grond van wet- en regelgeving een certificaat behaald moet worden om de bekwaamheid aan te tonen (POR: Sectoren gespiegeld).

I6. https://abonneren.rijksoverheid.nl/media/40/66/603531/2I48/lijst_applicaties.pdf

I7. Toelatingseisen leergangen en kernopgaven post-initieel onderwijs, 26 januari 20I2, pp3-8. 
nascholing of trainingen met betrekking tot algemene onderwerpen zoals assertiviteit of gespreksvaardigheden.

\subsection{Huidig opleidings- en trainingsbeleid}

\subsubsection{Toe- of afwijzing van opleidingsverzoeken}

Allereerst is onderzocht of leidinggevenden in de afgelopen drie jaar vanuit hun medewerkers het verzoek hebben gekregen voor het volgen van een opleiding. Een verzoek vanuit politiemensen om een vervolgopleiding te mogen volgen, geeft namelijk al een gedeeltelijke zelfmelding aan.

Uit de analyses blijkt dat $94 \%$ van de leidinggevende respondenten de afgelopen drie jaar ten minste één opleidingsverzoek van zijn/haar medewerkers heeft gekregen. Ongeveer één op de vijf leidinggevenden geeft aan de afgelopen drie jaar van meer dan de helft van de medewerkers een opleidingsverzoek te hebben gekregen. ${ }^{18}$ Dit lijkt aan te geven dat vrijwel alle leidinggevenden in bepaalde mate, en een aanzienlijk deel zelfs in sterke mate, ervaring hebben met medewerkers die zelf initiatief tonen met betrekking tot een bepaalde opleidingswens of -behoefte.

Of dit verzoek daadwerkelijk tot deelname aan een opleiding heeft geleid, hangt mede af van het opleidings- en trainingsbeleid van de betrokken leidinggevende. Daarom is aan de leidinggevenden gevraagd of ze in de afgelopen drie jaar opleidingsverzoeken van medewerkers hebben afgewezen. Tevens hebben we gevraagd om welke opleidingen het ging bij deze afgewezen verzoeken en wat de reden was voor de afwijzing. Iets minder dan de helft van de leidinggevenden (47\%) geeft aan in de afgelopen drie jaar geen enkel verzoek tot het volgen van een opleiding van een medewerker te hebben afgewezen (Tabel 2.I). We zien dat hoe minder opleidingsverzoeken de leidinggevenden hebben gekregen, hoe vaker ze aangeven geen enkel opleidingsverzoek te hebben afgewezen.

Van de leidinggevenden die de afgelopen drie jaar één of meerdere opleidingsverzoeken van medewerkers hebben afgewezen, heeft 6I\% (onder andere) een verzoek tot het volgen van een specialistische opleiding afgewezen, 25\% wees (onder andere) een verzoek tot het volgen van een functiegerichte applicatie af en $19 \%$ heeft (onder andere) een opleidingsverzoek voor een leidinggevende opleiding afgewezen.

I8. Gemiddeld geven deze leidinggevenden, die de afgelopen drie jaar van meer dan de helft van de medewerkers een opleidingsverzoek hebben gekregen, leiding aan 35 medewerkers. 
Tabel 2.1

Afgewezen opleidingsverzoeken per aantal opleidingsverzoeken

$\begin{array}{llll} & \text { Afgewezen opleidingsverzoeken? } & \\ \text { Aantal opleidingsverzoeken } & \text { Ja } & \text { Nee } & \text { Totaal } \\ \text { Van een enkeling } & 49 \% & 51 \% & 100 \% \\ \text { Van minder dan de helft van de medewerkers } & 53 \% & 47 \% & 100 \% \\ \text { Van meer dan de helft van de medewerkers } & 61 \% & 39 \% & 100 \% \\ \text { Totaal } & 53 \% & 47 \% & 100 \%\end{array}$

Bron: ROA enquête onder politiemensen

De meest genoemde reden voor het afwijzen van een verzoek tot het volgen van specialistische opleidingen en functiegerichte applicaties is dat het niet in het beschikbare opleidingsbudget paste. Deze reden werd genoemd door $38 \%$ van de leidinggevenden die een specialistische opleiding hadden afgewezen en door 50\% van de leidinggevenden die een functiegerichte applicatie hadden afgewezen. De specialistische opleidingen zijn bovendien relatief vaak afgewezen omdat de leidinggevende vond dat de opleiding niet relevant was voor het werk (30\%). Deze reden wordt bij de afwijzingen voor functiegerichte applicaties door $15 \%$ van de leidinggevenden genoemd. Van de leidinggevenden die (onder andere) een functiegerichte applicatie hadden afgewezen, geeft $\mathrm{I}_{2} \%$ aan dat ze dat deden omdat de opleiding een te groot beslag zou leggen op de operationele capaciteit. Tot slot is het opvallend dat geen enkele leidinggevende aangeeft een opleidingsverzoek te hebben afgewezen omdat de desbetreffende collega pas geleden nog een opleiding had gevolgd.

\subsubsection{Speerpunten leidinggevenden}

Het toewijzen of afwijzen van een opleidingsverzoek kan afhankelijk zijn van de visie van leidinggevenden op de begeleiding van medewerkers. Daarom is aan de leidinggevenden gevraagd wat hun belangrijkste speerpunten zijn bij de begeleiding van medewerkers, waarbij maximaal drie antwoorden konden worden gegeven.

In Figuur 2.I is te zien dat veruit de meeste leidinggevenden (69\%) het bevorderen van de inzetbaarheid van medewerkers als een van de belangrijkste speerpunten noemen. Ook noemen veel leidinggevenden loopbaanontwikkeling als een van de belangrijkste speerpunten $(46 \%)$. Dat deze twee speerpunten het vaakst worden genoemd is een teken dat leidinggevenden er waarschijnlijk oog voor hebben dat hun medewerkers als nodig vervolgopleidingen volgen ten behoeve van hun eigen inzetbaarheid of ontwikkeling.

Leidinggevenden die vermindering van werkdruk of doorstroom als een van hun belangrijkste speerpunten noemen, geven relatief vaak aan dat ze in de afgelopen drie jaar geen enkel opleidingsverzoek hebben afgewezen (60\%, resp. 52\%). Daarentegen hebben leidinggevenden die het verminderen van verzuim of het functioneren van oudere medewerkers als een van hun belangrijkste speerpunten noemen, relatief vaak 
een of meerdere opleidingsverzoeken afgewezen (60\%, resp. 58\%). Leidinggevenden die vermindering van verzuim als een van de speerpunten noemen, wezen relatief vaak een verzoek tot het volgen van een specialistische opleiding of leidinggevende opleiding af. ${ }^{19}$

Figuur 2.1

Speerpunten leidinggevenden

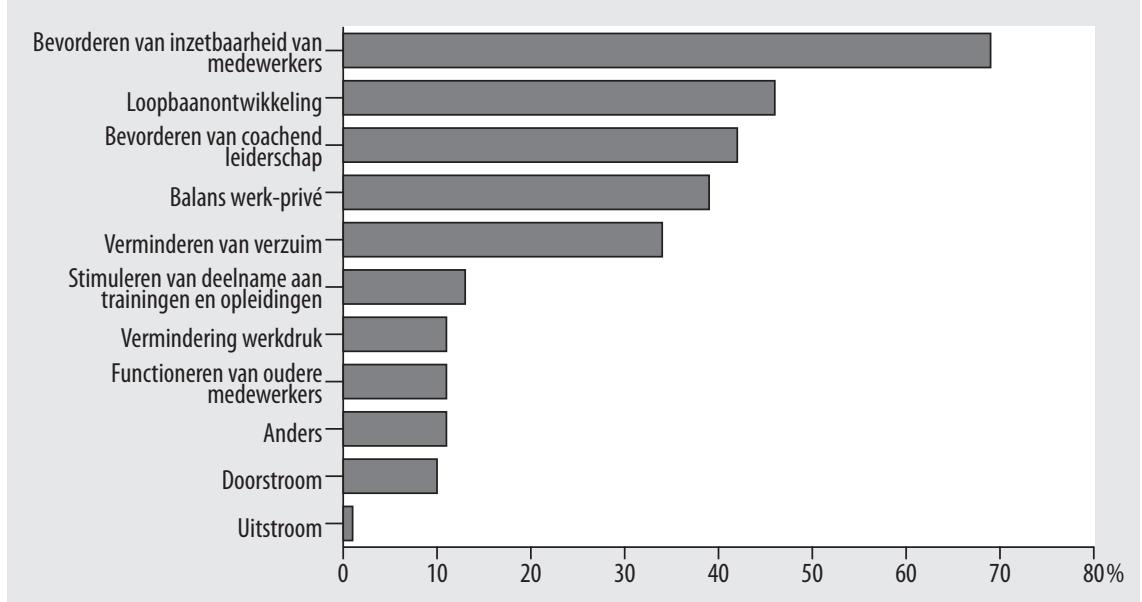

Bron: ROA enquête onder politiemensen

\subsubsection{Aandacht voor functioneren en/of loopbaanontwikkeling binnen teams}

Gemiddeld geven leidinggevenden aan dat zij per maand 37\% van hun tijd besteden aan het functioneren, het leren en de ontwikkeling van hun medewerkers. Uit Tabel 2.2 is af te leiden dat deze tijd waarschijnlijk vooral aan jaargesprekken, werkoverleg en regelmatige feedback wordt besteed. Meer dan de helft van alle medewerkers (leidinggevenden en niet-leidinggevenden) werkt namelijk in een team waar via één of meerdere van deze instrumenten aandacht wordt besteed aan hun functioneren en/ of loopbaanontwikkeling.

19. Het aantal respondenten dat het functioneren van oudere medewerkers als speerpunt noemt én heeft aangegeven welke opleidingen zijn afgewezen is te klein voor verdere analyses $(n=I I)$. 
Tabel 2.2

Aandacht voor functioneren en/of loopbaanontwikkeling

\begin{tabular}{ll} 
Besteedt het team waar u werkt aandacht aan uw functioneren en/of loopbaanontwikkeling via: \\
jaargesprekken & $76 \%$ \\
werkoverleg & $69 \%$ \\
regelmatige feedback van collega's & $65 \%$ \\
regelmatige feedback van leidinggevende & $52 \%$ \\
hulp bij het maken van POP & $45 \%$ \\
\hline mogelijkheid tot functieroulatie/taakroulatie & $30 \%$
\end{tabular}

Bron: ROA enquête onder politiemensen

De mate waarin in teams aandacht wordt besteed aan iemands functioneren of loopbaan blijkt verschillend te zijn tussen de domeinen waarin men werkzaam is. Dit is weergegeven in Figuur 2.2.

Figuur 2.2

Aandacht aan functioneren en/of loopbaanontwikkeling in teams per domein

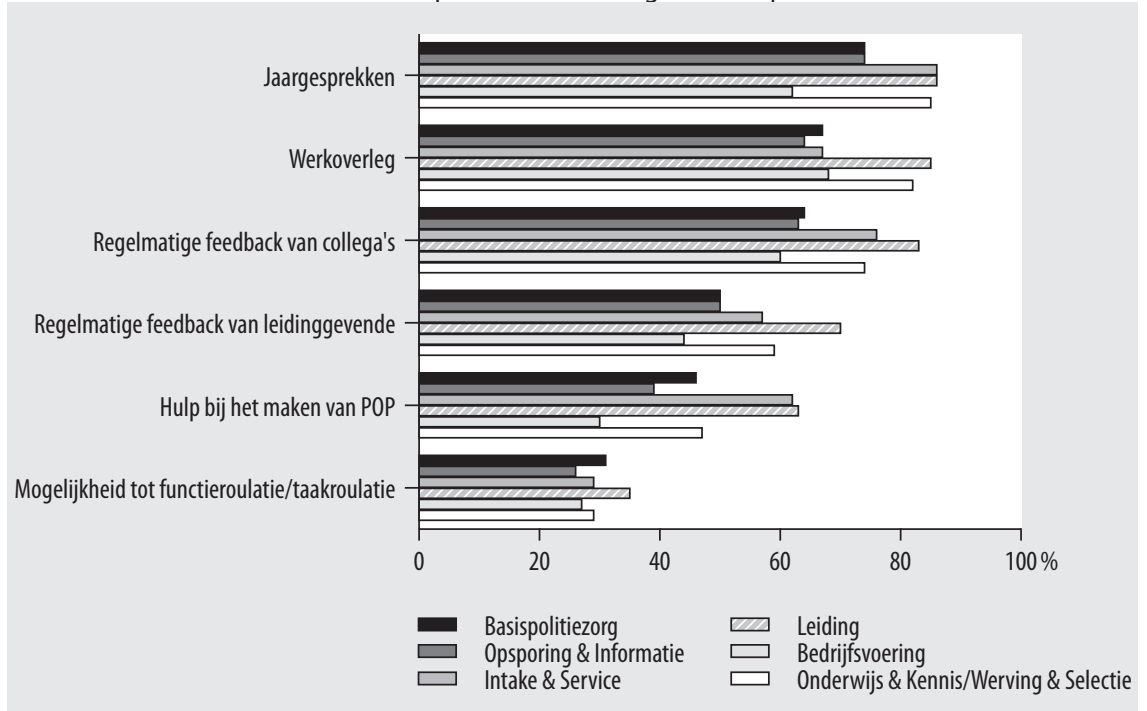

Bron: ROA enquête onder politiemensen

De politiemensen die werkzaam zijn in het domein bedrijfsvoering geven relatief het minst vaak aan in een team te werken waar aandacht wordt besteed aan hun functioneren of loopbaanontwikkeling: bij alle instrumenten scoren zij het laagst. Zij geven relatief weinig aan dat er via jaargesprekken of hulp bij het maken van een persoonlijk ontwikkelingsplan aandacht wordt besteed aan hun functioneren of loopbaanontwikkeling. Ook de medewerkers in de domeinen 'basispolitiezorg' en 'opsporing \& informatie' geven relatief weinig aan dat ze in een team werken waar aandacht aan hun functioneren en/of loopbaanontwikkeling wordt besteed. 
De medewerkers werkzaam in het domein 'leiding' scoren daarentegen bij alle instrumenten het hoogst, wat betekent dat zij het vaakst aangeven in een team te werken waar aandacht wordt besteed aan hun functioneren en/of loopbaanontwikkeling. Deze medewerkers geven relatief vaak aan dat er via regelmatige feedback van hun leidinggevende en/of collega's aandacht wordt besteed aan hun functioneren en/of loopbaanontwikkeling. Tevens zien we dat medewerkers in de domeinen 'intake $\&$ service' en 'onderwijs \& kennis/werving \& selectie' ook relatief vaak aangeven dat er aandacht aan hun functioneren en/of loopbaanontwikkeling wordt besteed.

\subsubsection{Bij wie hoort het initiatief voor het volgen van vervolgopleidingen te liggen?}

De leidinggevenden zijn - voor alle typen vervolgopleidingen - gevraagd bij wie zij vinden dat het initiatief moet liggen om die vervolgopleiding te gaan volgen. Dit moesten ze aangeven op een schuifbalk die liep van -IOO\% (initiatief voor het volgen van deze vervolgopleiding moet IOO\% bij de medewerker liggen) tot I00\% (initiatief voor het volgen van deze vervolgopleiding moet Ioo\% bij de leidinggevende liggen). In Figuur 2.3 is voor iedere vervolgopleiding zowel het interval van de antwoorden van 95\% van de leidinggevenden, als het gemiddelde antwoord van de leidinggevenden te zien. Als een verticale streep (het $95 \%$ betrouwbaarheidsinterval) volledig onder de $\mathrm{x}$-as valt, betekent dat dat de leidinggevenden het 'met elkaar eens zijn' dat het initiatief meer bij de medewerker dan bij de leidinggevende moet liggen, maar dat er variatie is in de mate waarin leidinggevenden vinden dat het zwaartepunt bij de medewerker moet liggen. Het omgekeerde geldt voor verticale strepen die volledig boven de $\mathrm{x}$-as vallen. Hoe dichter een verticale streep bij de $\mathrm{x}$-as ligt, hoe meer er voor die vervolgopleiding uit wordt gegaan van gezamenlijk initiatief. Hoe langer de verticale streep, hoe groter de variatie in de gegeven antwoorden.

Wat in het algemeen opvalt in Figuur 2.3 is dat de leidinggevenden, wat betreft het nemen van initiatief voor het volgen van een vervolgopleiding, niet negatief tegenover zelfmelden lijken te staan. Zouden ze hier wel negatief tegenover staan, dan zouden alle verticale strepen (veel verder) boven de x-as liggen. Voor het volgen van bepaalde vervolgopleidingen lijken ze zelfs te verwachten dat de medewerker iets meer het initiatief neemt dan zij zelf als leidinggevenden. $95 \%$ van de leidinggevenden is van mening dat het initiatief voor het volgen van (I) een initiële opleiding ten behoeve van doorstroom, (2) een specialistische opleiding of (3) een opleiding, bij- of nascholing buiten de Politieacademie, wat meer bij de medewerker dan bij de leidinggevende zou moeten liggen. Voor functiegerichte applicaties bevindt de verticale lijn zich zo dicht bij de $\mathrm{x}$-as dat leidinggevenden hier niet echt uitgesproken in zijn en er meer een gezamenlijkheid van het initiatief uit blijkt. Het initiatief voor het volgen van een leidinggevende opleiding zou volgens de leidinggevenden vrij gezamenlijk moeten 
zijn, hoewel er ook leidinggevenden zijn die vinden dat het initiatief iets meer bij de medewerker dan bij de leidinggevende zou moeten liggen, of vice versa. ${ }^{20}$

Figuur 2.3

Bij wie vinden leidinggevenden dat het initiatief moet liggen om vervolgopleidingen te volgen?

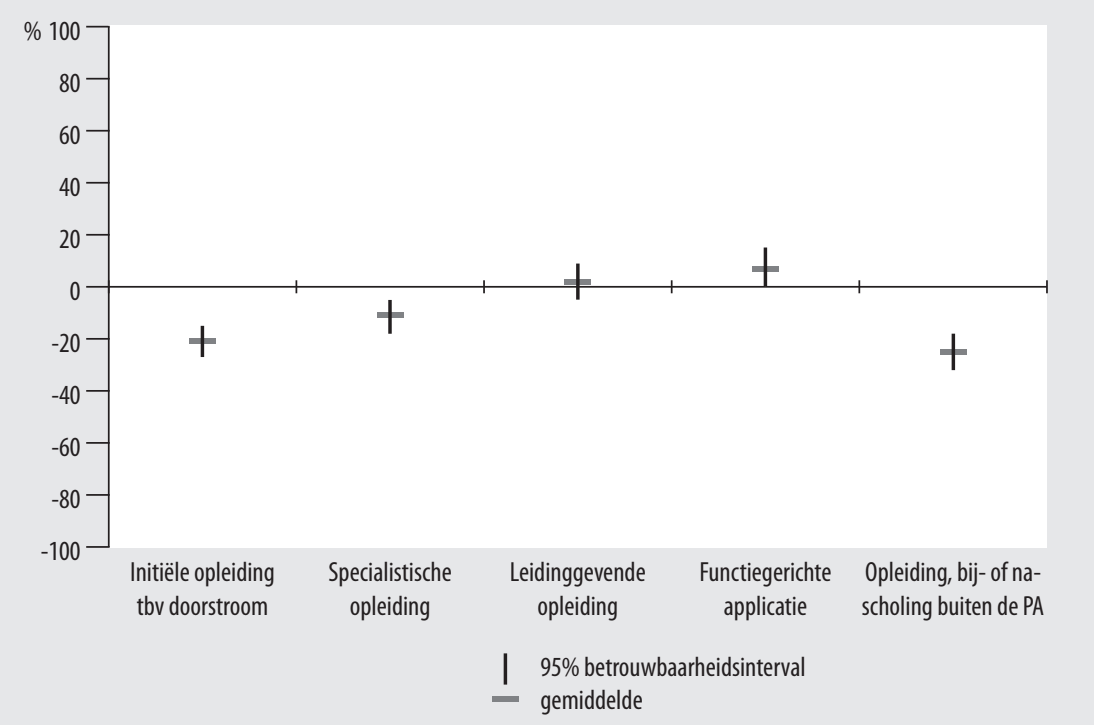

Bron: ROA enquête onder politiemensen

Noot : -100 betekent initiatief volledig bij de medewerker, +100 betekent initiatief volledig bij de leidinggevende.

\subsubsection{Gepercipieerd trainings- en opleidingsbeleid}

Het is mogelijk dat het trainings- en opleidingsbeleid zoals leidinggevenden dat aangeven te voeren, door medewerkers anders wordt beleefd. Daarom is aan de nietleidinggevende medewerkers gevraagd in hoeverre ze het eens zijn met een aantal stellingen die het trainings- en opleidingsbeleid van hun leidinggevende(n) beschrijven (Figuur 2.4).

20. Ter vergelijking: Initiële opleidingen ten behoeve van doorstroom en specialistische opleidingen zijn tot nu toe relatief vaak volledig op eigen initiatief gevolgd (58\%, respectievelijk $50 \%)$. Leidinggevende opleidingen zijn relatief weinig volledig op eigen initiatief $(38 \%)$ gevolgd. Dit is consistent met het beeld van leidinggevenden over bij wie het initiatief zou moeten liggen voor die typen opleiding. 
Figuur 2.4

Door niet-leidinggevenden gepercipieerd trainings- en opleidingsbeleid

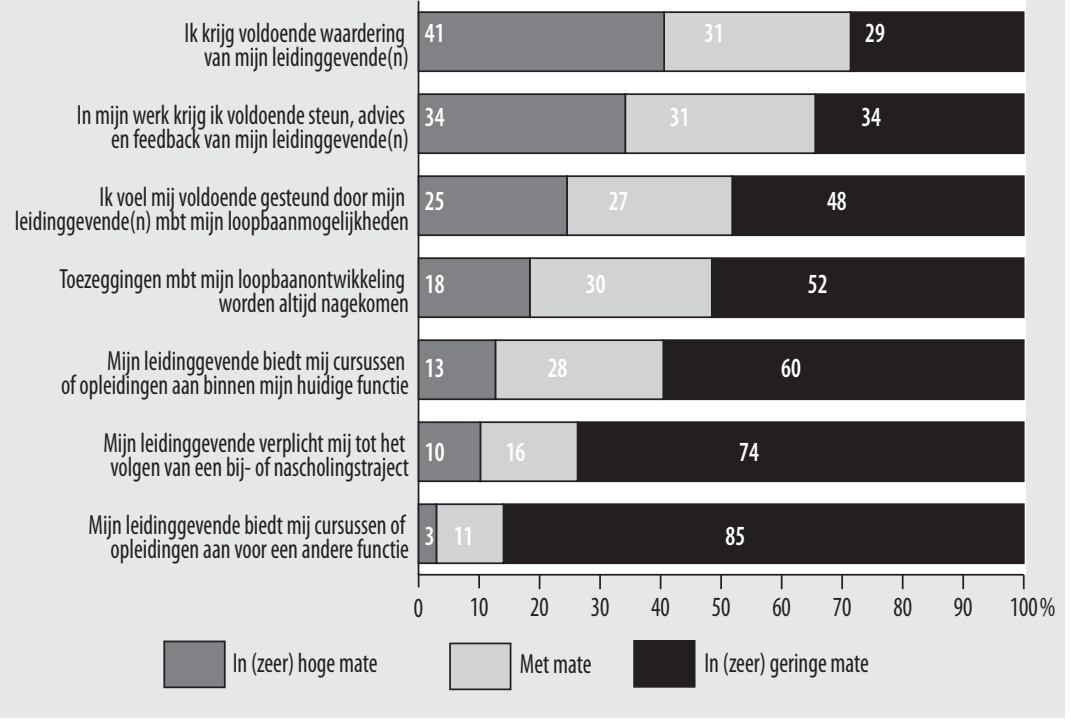

Bron: ROA enquête onder politiemensen

Medewerkers lijken over het algemeen niet ontevreden, maar eerder tevreden, te zijn met de waardering, steun, advies en feedback die ze van hun leidinggevenden krijgen. Daarentegen geeft ongeveer de helft van de medewerkers aan dat ze zich niet voldoende gesteund voelt door de leidinggevende(n) met betrekking tot loopbaanmogelijkheden en/of dat toezeggingen met betrekking tot loopbaanontwikkelingen niet altijd worden nagekomen. Met name het laatste punt kan zeer bepalend zijn voor de bereidheid tot zelfmelden in de toekomst. Uit de interviews blijkt namelijk dat de bereidheid om als zelfmelder een opleiding te gaan volgen toeneemt als daar een promotie-garantie tegenover staat. Deze cijfers laten echter zien dat een toezegging met betrekking tot loopbaanontwikkeling (zoals een toezegging dat er promotie gemaakt kan worden na het volgen van een vervolgopleiding) niet altijd een garantie is. In Hoofdstuk 6 wordt onderzocht in hoeverre de matige bereidheid tot zelfmelden bij gebrek aan loopbaangaranties werkelijk het geval is. 


\section{Opleidingsdeelname tot nu toe}

Ruim twee derde van de respondenten heeft de afgelopen drie jaar één of meerdere nietverplichte vervolgopleidingen gevolgd. Volledige zelfmelders zijn er daarbij nauwelijks (I\%). Het percentage politiemensen dat als gedeeltelijke zelfmelder aan een vervolgopleiding heeft deel genomen is echter niet gering. $84 \%$ van de respondenten geeft aan de meest recent gevolgde vervolgopleiding geheel of gedeeltelijk op eigen initiatief, buiten werktijd (in de vrije tijd) enlof op eigen kosten te hebben gevolgd. Het betrof hierbij voornamelijk respondenten die aangaven zelf (mede) het initiatief te hebben genomen voor de vervolgopleiding of deze deels in eigen tijd te hebben gevolgd. Het (mee) betalen aan een opleiding kwam zelden voor. Deze gedeeltelijke zelfmelders kwamen relatief wat vaker voor onder de jongere werknemers, de hogere rangen, de domeinen leiding, bedrijfsvoering en onderwijs o kennis/werving \& selectie, en onder medewerkers die een hoger verantwoordelijkheidsgevoel hebben voor hun kennis, vaardigheden en ontwikkeling en onder medewerkers die het leuk vinden om te leren. 


\subsection{Inleiding}

In paragraaf 3.2 kijken we naar de opleidingsdeelname in de afgelopen drie jaar. Paragraaf 3.3 onderzoekt de factoren die politiemensen motiveerden om deze opleidingen te volgen. Om een beeld te krijgen in hoeverre er tot op heden sprake is van het fenomeen zelfmelden, wordt in paragraaf 3.4 onderzocht in hoeverre politiemensen de afgelopen drie jaar (gedeeltelijke) zelfmelders zijn geweest. De kenmerken van (gedeeltelijke) zelfmelders en niet-zelfmelders worden geanalyseerd aan de hand van persoon- en werk-gerelateerde kenmerken en persoonlijkheidskenmerken.

\subsection{Opleidingsdeelname in de afgelopen drie jaar}

In deze paragraaf gaan we eerst in op de algemene werk-gerelateerde opleidingsdeelname van politiemensen tot nu toe. We kijken hierbij naar alle typen opleiding en maken hierbij nog geen onderscheid tussen initieel en (al dan niet) verplichte postinitiële opleidingen. Hierdoor schetsen we een algemeen beeld van de opleidingsdeelname bij de politie. Vervolgens gaan we in op de deelname aan vervolgopleidingen met een niet-verplicht karakter. Deze zijn, ook in de enquête die de respondenten hebben beantwoord, gedefinieerd als in Tekstbox 3.I aangegeven.

Tekstbox 3.1 Definitie van het begrip 'vervolgopleiding', zoals gehanteerd in de enquête Bij vervolgopleidingen moet u denken aan opleidingen gericht op het bijblijven in uw vak, het verdiepen of verbreden van uw kennis of vaardigheden of opleidingen gericht op loopbaanverandering. Het gaat hier om werk-gerelateerde opleidingen die niet-verplicht zijn.

Voor de verdere analyses in dit onderzoek is het belangrijk om dit onderscheid te maken omdat bij opleidingen die verplicht zijn, zoals hercertificeringen, per definitie geen eigen initiatief of inbreng van medewerkers in termen van tijd of geld mogelijk is. Opleidingen met een volledig verplicht karakter zijn hierdoor voor de verdere analyses in dit onderzoek niet relevant om mee te nemen.

Ten eerste bespreken we de deelname aan werk-gerelateerde opleidingen in het algemeen. Respondenten is gevraagd aan welke soorten werk-gerelateerde opleidingen ze in de afgelopen drie jaar hebben deelgenomen. Uit de antwoorden blijkt dat de algemene opleidingsdeelname zeer hoog is: $80 \%$ gaf aan de afgelopen drie jaar aan één of meerdere werk-gerelateerde opleidingen te hebben deelgenomen. In Figuur 3.I is weergegeven om welke opleidingen het gaat. Iets meer dan IO\% heeft de afgelopen drie jaar een initiële opleiding gevolgd om bij de politie aan de slag te kunnen. Iets meer dan $5 \%$ heeft een initiële opleiding gevolgd om door te kunnen stromen. 
Figuur 3.1

Gevolgde opleidingen de afgelopen drie jaar

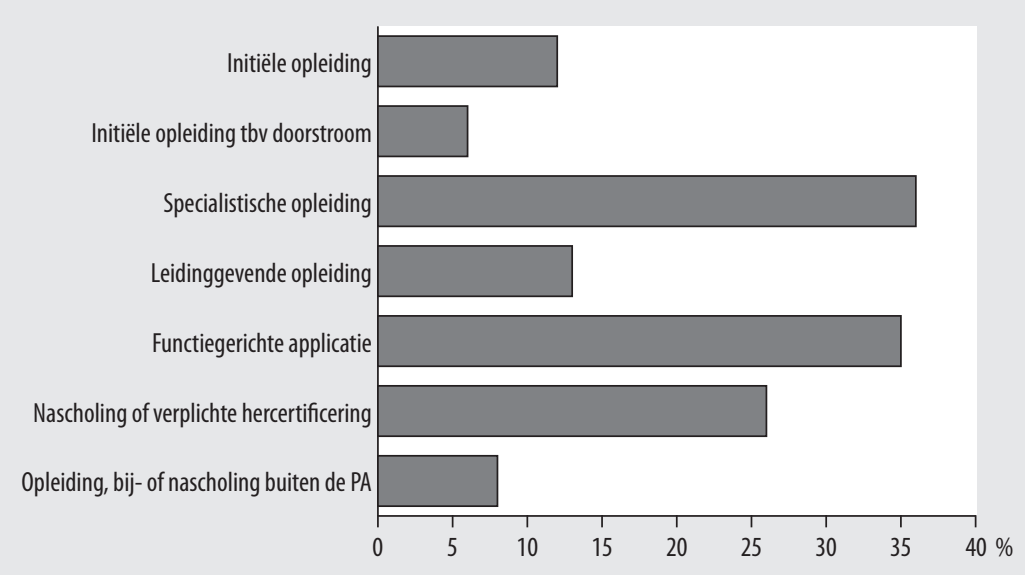

Bron: ROA enquête onder politiemensen

De jongere medewerkers ( $3 \mathrm{I} \mathrm{t} / \mathrm{m} 40$ jaar), de inspecteurs en de medewerkers in de domeinen 'opsporing \& informatie' en 'leiding' zijn degenen die relatief vaak één of meerdere opleidingen hebben gevolgd in de afgelopen drie jaar. Onder oudere werknemers ( $55 \mathrm{t} / \mathrm{m} 64$ jaar) en binnen de rangen 'operationeel overigen' en 'brigadiers' komt het relatief vaak voor dat in de afgelopen drie jaar geen enkele opleiding is gevolgd. Dit geldt ook voor medewerkers in het domein 'bedrijfsvoering' De opleidingsdeelname verschilt nauwelijks tussen mannen en vrouwen.

Ten tweede de vervolgopleidingen. 68\% van alle respondenten heeft in de afgelopen drie jaar één of meerdere vervolgopleidingen gevolgd. Figuur 3.2 geeft aan wat de meest recente gevolgde vervolgopleiding van politiemensen is. Voor veruit de meeste respondenten was een specialistische opleiding of niet-verplichte functiegerichte applicatie de meest recent gevolgde vervolgopleiding. Initiële opleidingen ten behoeve van doorstroom zijn relatief het minst vaak genoemd als de meest recente vervolgopleiding. 


\section{Figuur 3.2}

Meest recent gevolgde vervolgopleiding

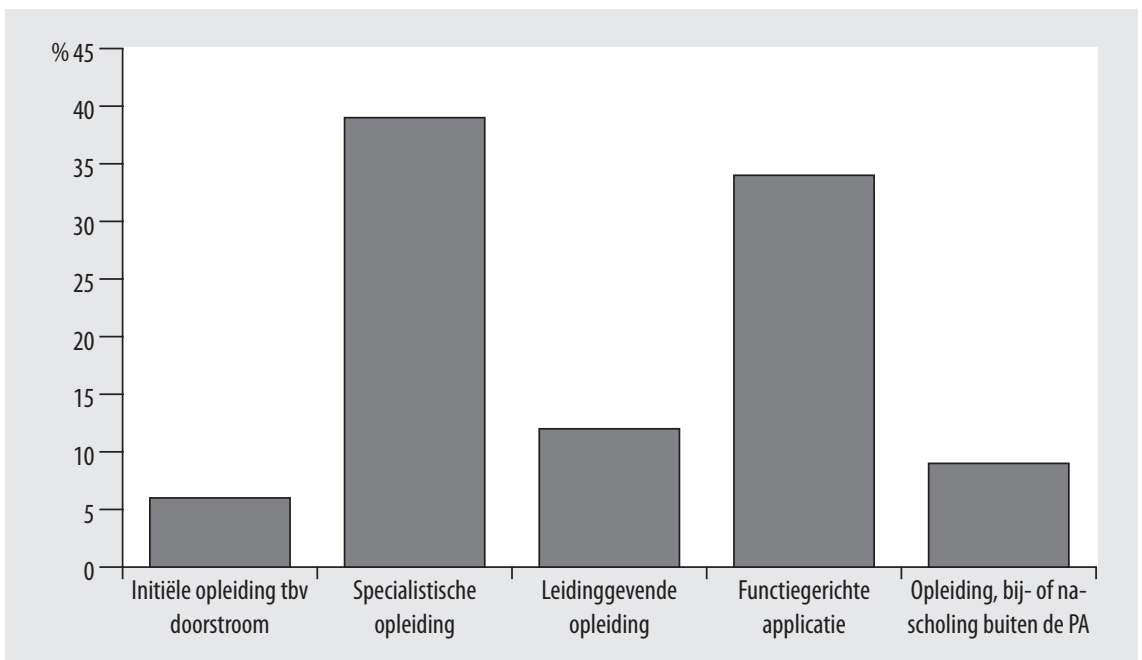

Bron: ROA enquête onder politiemensen

\subsection{Wie heeft de afgelopen drie jaar aan een vervolgopleiding deelgenomen?}

We gaan nu kort in op de vraag wie de afgelopen drie jaar een vervolgopleiding gevolgd heeft. We bekijken achtereenvolgens een aantal persoon- en werk-gerelateerde factoren.

\section{Persoonskenmerken}

\section{Geslacht}

Of men in de afgelopen drie jaar al dan niet een vervolgopleiding heeft gevolgd is niet afhankelijk van geslacht. Ook in de keuze voor een type vervolgopleiding zijn geen significante verschillen tussen mannen en vrouwen. Het ontbreken van een verschil in scholingsdeelname tussen mannen en vrouwen is niet uniek voor de politiesector, maar is kenmerkend voor heel Nederland. ${ }^{21}$

\section{Leeftijd}

Figuur 3.3 toont de deelname aan vervolgopleidingen naar leeftijd. De jongste respondenten (<3I jaar) en de oudste medewerkers ( $>60$ jaar) hebben in de afgelopen drie

2I. In 2010 was de cursusdeelname onder werkende mannen en vrouwen voor het eerst gelijk. In de jaren 2004 en 2007 trainden werkende mannen gemiddeld nog meer dan vrouwen (Borghans, Fouarge en De Grip (20II). Een leven lang leren in Nederland. ROA-R-20II/5. ROA, Maastricht). 
jaar relatief weinig aan vervolgopleiding(en) deelgenomen. De gemiddelde vervolgopleidingsdeelname van de medewerkers tussen de 40 en 62 jaar is niet significant verschillend. Dit komt met name doordat in alle leeftijdscategorieën meer dan de helft van de respondenten een vervolgopleiding heeft gevolgd, waardoor er relatief weinig variatie mogelijk is. De figuur laat verder zien dat de gemiddelde vervolgopleidingsdeelname onder medewerkers tussen de 40 en 50 jaar varieert van $55 \%$ tot $90 \%$. De gemiddelde vervolgopleidingsdeelname van de medewerkers ouder dan 50 varieert minder, maar neemt naar mate de leeftijd van de medewerkers toeneemt wel geleidelijk af. Desondanks ligt de opleidingsdeelname van oudere medewerkers absoluut gezien nog steeds op een hoog niveau.

\section{Figuur 3.3}

Gemiddelde vervolgopleidingsdeelname per leeftijd ${ }^{22}$

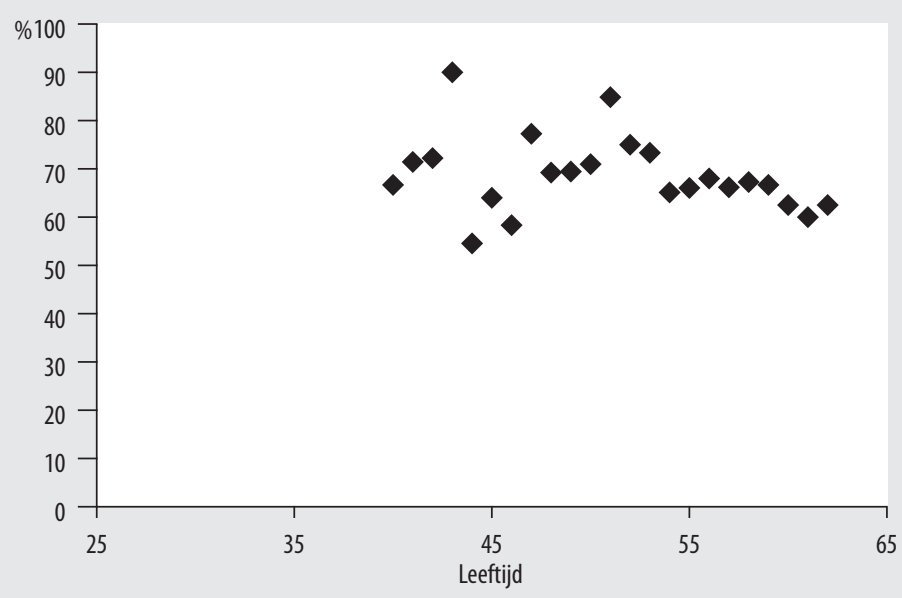

Bron: ROA enquête onder politiemensen

In Figuur 3.4 zien we per leeftijdscategorie wat voor soort vervolgopleiding politiemensen gevolgd hebben. Ten eerste zien we dat hoe ouder de respondenten zijn, hoe minder vaak zij een initiële opleiding ten behoeve van doorstroom hebben gevolgd. Daarentegen blijkt dat zij vaker aan een leidinggevende opleiding hebben deelgenomen. Ook zien we dat er bij de oudste groep respondenten gemiddeld vaker een functiegerichte applicatie wordt gevolgd dan bij de jongere groepen. Een relatief hoge deelname aan specialistische opleidingen zien we bij de werknemers in de leeftijden van 25-34 jaar en 45-54 jaar.

22. We hebben leeftijden weggelaten met minder dan 20 personen. Er hebben betrekkelijk weinig jonge politiemensen deelgenomen aan de enquête en daardoor zijn in de figuur geen gemiddeldes weergegeven voor politiemensen jonger dan 40 jaar. 


\section{Figuur 3.4}

Type vervolgopleiding per leeftijdscategorie

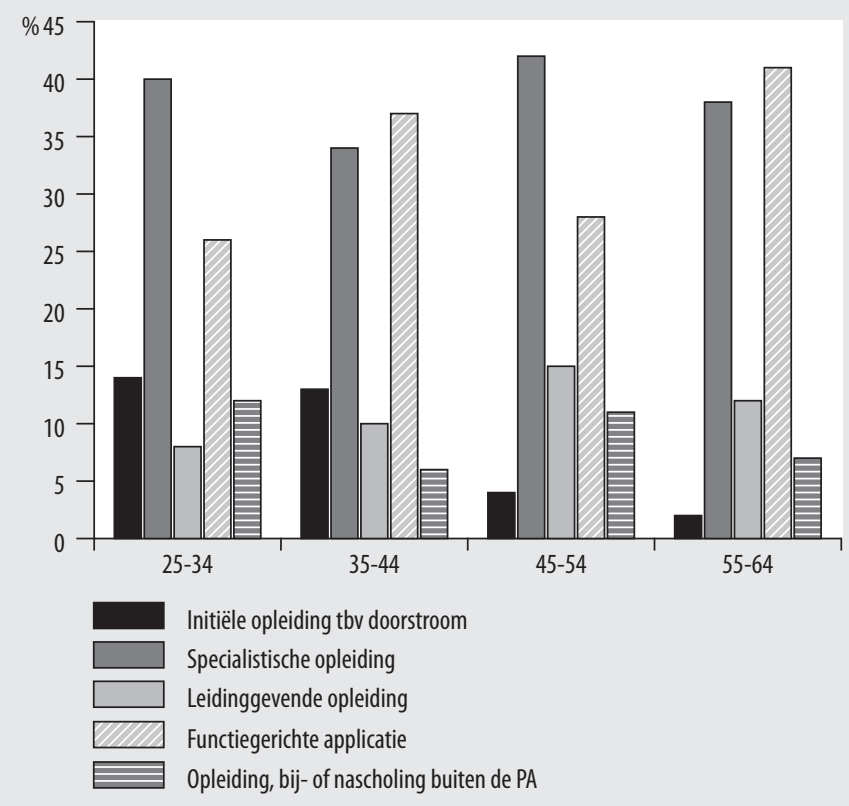

Bron: ROA enquête onder politiemensen

\section{Werk-gerelateerde factoren}

We bekijken verder of rang en domein bepalend zijn voor deelname aan (een bepaald type) vervolgopleidingen gedurende de laatste drie jaar.

\section{Rang}

Uit Figuur 3.5 blijkt dat medewerkers met hogere rangen de afgelopen drie jaar gemiddeld vaker een vervolgopleiding hebben gevolgd dan medewerkers met lagere rangen. Aspiranten zitten nog in hun initiële opleiding, waardoor hun deelname aan vervolgopleidingen logischerwijs laag is. De opleidingsdeelname van politiemensen in de rang van agent is lager dan gemiddeld omdat de rang van agent doorgaans de eerste rang is waarin politiemensen na hun initiële opleiding werkzaam zijn. Deze initiële opleiding is dermate omvangrijk dat men de eerste jaren als agent vooral werkervaring moet opdoen en qua opleiding relatief minder nodig heeft dan in de daarna volgende rangen. 
Figuur 3.5

Vervolgopleidingsdeelname per rang

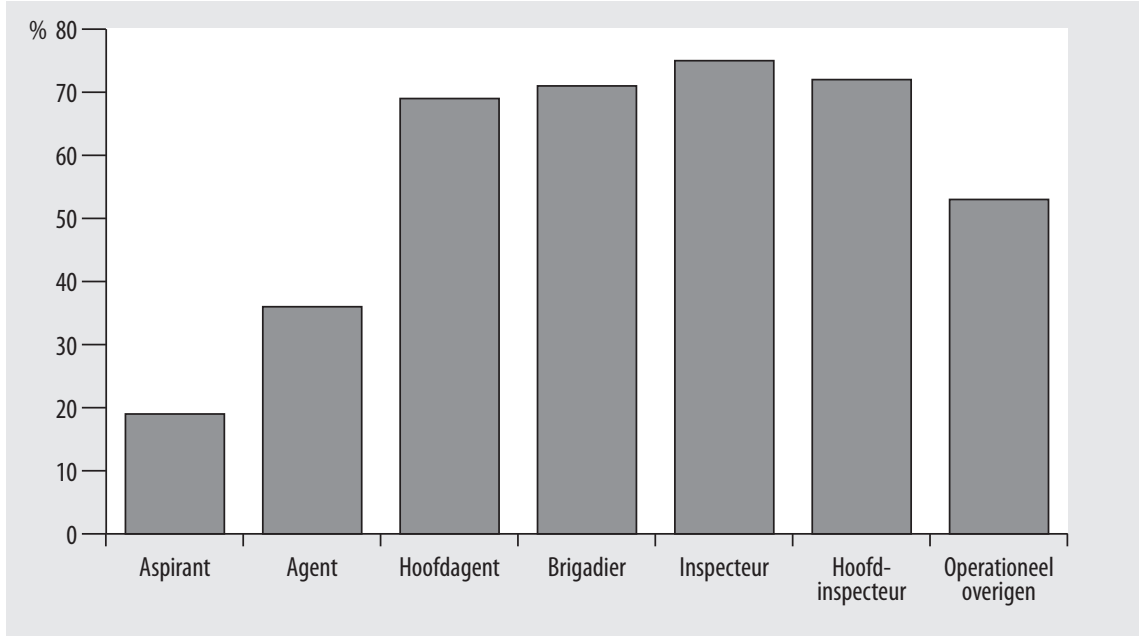

Bron: ROA enquête onder politiemensen

In Figuur 3.6 wordt per rang weergegeven welke vervolgopleidingen gevolgd zijn. Aan het begin van dit hoofdstuk is vermeld dat de rang brigadier de laagste rang is met leidinggevende taken. Het is dan ook niet verrassend dat hoofdagenten niet aan leidinggevende opleidingen hebben deelgenomen, en dat de gemiddelde deelname vanaf brigadier stijgt met de rang. Ook neemt de gemiddelde deelname aan opleiding, bij- of nascholing buiten de Politieacademie toe naarmate de rang hoger wordt.

De twee populairste vervolgopleidingen van de totale groep respondenten - de specialistische opleidingen en functiegerichte applicaties (zie Figuur 3.2) - zijn ook verreweg de populairste vervolgopleidingen onder de groepen 'operationeel overigen', 'hoofdagenten' en 'brigadiers'. Dit is niet het geval onder de inspecteurs en hoofdinspecteurs, vanwege hun relatief grote deelname aan leidinggevende opleidingen en aan opleidingen buiten de Politieacademie. 


\section{Figuur 3.6}

Type vervolgopleiding per rang

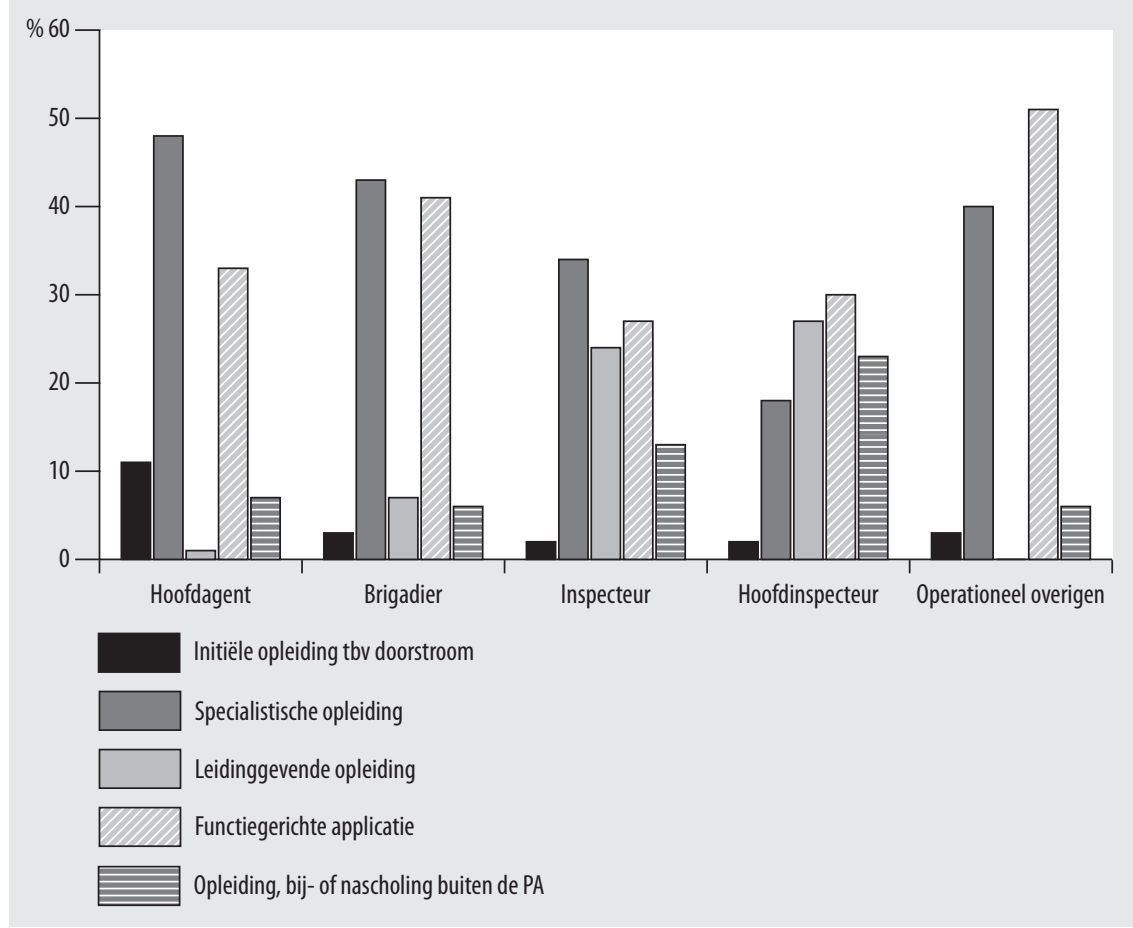

Bron: ROA enquête onder politiemensen

\section{Domein}

We gaan nu in op het volgen van vervolgopleidingen naar domein waarin politiemensen werkzaam zijn. Wat betreft de vervolgopleidingsdeelname zijn de domeinen op te delen in drie categorieën:

- De respondenten die werkzaam zijn in de domeinen 'leiding' en 'opsporing $\&$ informatie' hebben gemiddeld het vaakst aan een of meerdere vervolgopleidingen deelgenomen (85\%, respectievelijk 75\%).

- De vervolgopleidingsdeelname onder de respondenten werkzaam in de domeinen 'basispolitiezorg', 'onderwijs \& kennis/werving \& selectie' en 'intake \& service' is ongeveer $65 \%$.

- De respondenten werkzaam in het domein 'bedrijfsvoering' hebben het minst vaak aan een vervolgopleiding deelgenomen. Onder hen is de gemiddelde vervolgopleidingsdeelname $49 \%$.

In Figuur 3.7 is het type gevolgde vervolgopleiding per domein weergegeven. Zoals verwacht worden leidinggevende opleidingen relatief vaak door respondenten uit het domein leiding gevolgd, maar ook binnen het domein 'onderwijs \& kennis/werving 
\& selectie' is dit een relatief vaak gevolgd type vervolgopleiding. Binnen het domein 'opsporing \& informatie' zijn relatief vaak specialistische opleidingen gevolgd. Binnen het domein 'bedrijfsvoering' en 'onderwijs \& kennis/werving \& selectie' zijn relatief vaak opleidingen, bij- of nascholingen buiten de Politieacademie gevolgd. Dit zou te maken kunnen hebben met het meer algemene karakter de functies binnen deze domeinen. Het is voor de uitoefening van de functies in deze domeinen niet altijd nodig om een initiële opleiding bij de Politieacademie te hebben, waardoor voor politiemensen in deze domeinen vervolgopleidingen buiten de Politieacademie meer voor de hand liggend zijn dan voor medewerkers in andere domeinen.

\section{Figuur 3.7}

Type vervolgopleiding per domein

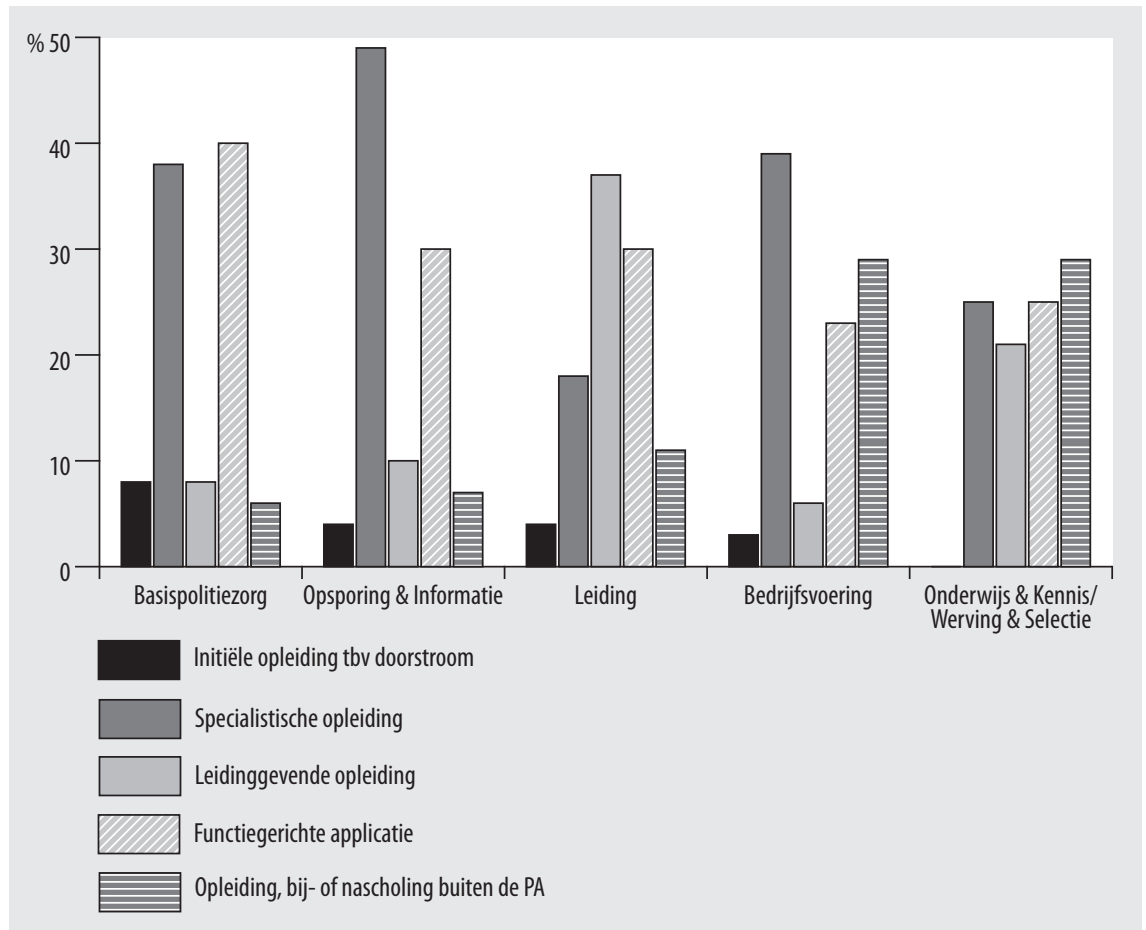

Bron: ROA enquête onder politiemensen

\subsection{Redenen voor het volgen van vervolgopleidingen}

Om inzicht te krijgen in de manier waarop vervolgopleidingsdeelname in de toekomst gestimuleerd zou kunnen worden, is het van belang om de motivatie voor de reeds gevolgde vervolgopleiding in kaart te brengen. Daarom is aan de respondenten gevraagd wat hun belangrijkste reden was om aan de laatste vervolgopleiding 
deel te nemen. Het was hierbij slechts mogelijk één antwoord te geven. Een overzicht van de belangrijkste redenen genoemd voor deelname aan vervolgopleidingen is weergegeven in Figuur 3.8.

Veruit de vaakst genoemde reden is "om mij verder te specialiseren" (37\%). Andere veel genoemde redenen zijn "om bij te blijven" (I8\%) en "om promotie te kunnen maken / door te kunnen groeien" (I6\%). Twee van de drie meest genoemde redenen hebben betrekking op verdieping / verticale ontwikkeling. Voor vrijwel niemand is hun persoonlijke ontwikkeling (I\%) of de mogelijkheid om buiten de politie aan de slag te kunnen (I\%) de belangrijkste reden voor hun opleidingsdeelname.

\section{Figuur 3.8}

Belangrijkste reden om aan de laatste vervolgopleiding deel te nemen

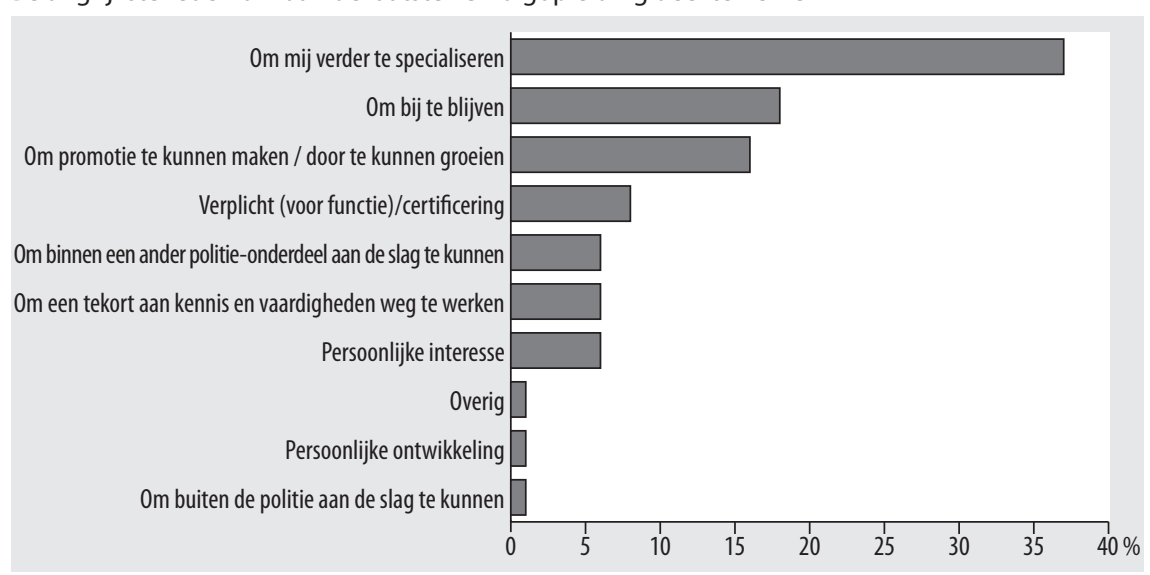

Bron: ROA enquête onder politiemensen

We bekijken nu voor de drie meest genoemde redenen of persoon- en werk-gerelateerde factoren van invloed zijn op de genoemde reden om aan de vervolgopleiding deel te nemen.

\section{Persoonskenmerken}

\section{Geslacht}

Er zijn vrijwel geen verschillen tussen mannen en vrouwen in hun motivatie voor het volgen van een vervolgopleiding. Wel geven mannen iets vaker dan vrouwen aan dat ze een vervolgopleiding hebben gevolgd om een tekort aan kennis en vaardigheden weg te werken. Dit verschil blijkt echter niet significant te zijn. 


\section{Leeftijd}

Figuur 3.9 toont binnen vier leeftijdsgroepen hoe belangrijk de drie in Figuur 3.8 meest genoemde redenen voor het volgen van een vervolgopleiding zijn. Niet onverwacht geven de oudere respondenten relatief vaker aan dat ze een vervolgopleiding hebben gevolgd om bij te blijven, maar is promotie maken/door kunnen groeien een relatief minder vaak genoemde reden dan onder de jongere respondenten. De 35-44 jarigen geven gemiddeld het vaakst aan dat ze een vervolgopleiding hebben gevolgd om zich verder te specialiseren.

\section{Figuur 3.9}

Reden voor gevolgde vervolgopleiding per leeftijdscategorie

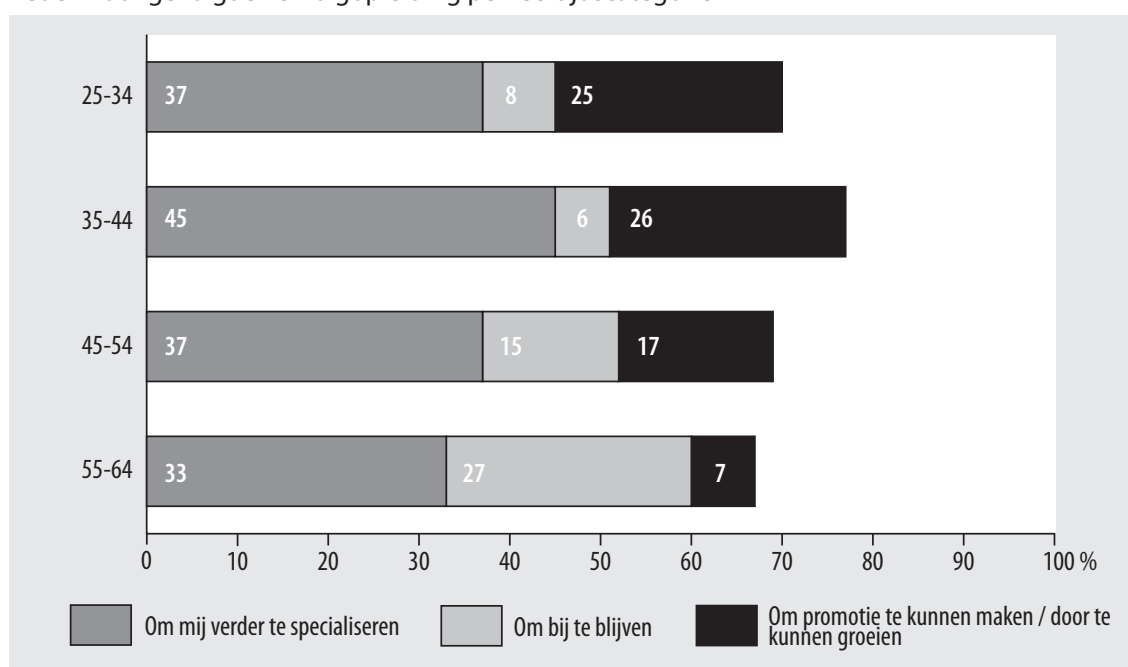

Bron: ROA enquête onder politiemensen

Noot: Omdat de andere redenen uit Figuur 3.8 hier buitenbeschouwing zijn gelaten, tellen de percentages binnen de leeftijdsgroepen niet op tot 100 .

\section{Werk-gerelateerde factoren}

Naast de factoren rang en domein, bekijken we ook of het type vervolgopleiding dat politiemensen gevolgd hebben gerelateerd is aan de reden voor scholingsdeelname.

\section{Type vervolgopleiding}

In Figuur 3.Io is per type vervolgopleiding weergegeven, wat de belangrijkste reden is om aan die opleiding deel te nemen. Initiële opleidingen ten behoeve van doorstroom zijn zoals verwacht door de meerderheid van de respondenten gevolgd om promotie te kunnen maken / door te kunnen groeien. Deze opleidingen zijn relatief weinig gevolgd om zich verder te specialiseren of om bij te blijven. Daarnaast zijn de initiële 
opleidingen ten behoeve van doorstroom relatief vaak gevolgd om bij een ander politieonderdeel aan de slag te kunnen (II\%).

Zoals verwacht zijn de specialistische opleidingen door de meerderheid gevolgd om zich verder te specialiseren. Deze opleidingen zijn daarentegen relatief weinig gevolgd om promotie te kunnen maken / door te kunnen groeien of om bij te blijven.

De meeste respondenten die een leidinggevende opleiding hebben gevolgd, deden dat om promotie te kunnen maken / door te kunnen groeien (4I\%) of om zich verder te specialiseren (I8\%). Daarnaast zijn leidinggevende opleidingen relatief vaak gevolgd om een tekort aan kennis en vaardigheden weg te werken (II\%). Leidinggevende opleidingen zijn relatief weinig gevolgd om bij te blijven.

Een derde van de respondenten, die hebben deelgenomen aan functiegerichte applicaties, deed dit om zich verder te specialiseren. Nogmaals een derde deed dit om bij te blijven. De meest genoemde reden om buiten de Politieacademie een vervolgopleiding te volgen is om promotie te kunnen maken / door te kunnen groeien (25\%). Opleidingen buiten de Politieacademie zijn vergeleken met andere typen opleidingen weinig gevolgd om te specialiseren.

\section{Figuur 3.10}

Belangrijkste reden voor gevolgde vervolgopleiding per type vervolgopleiding

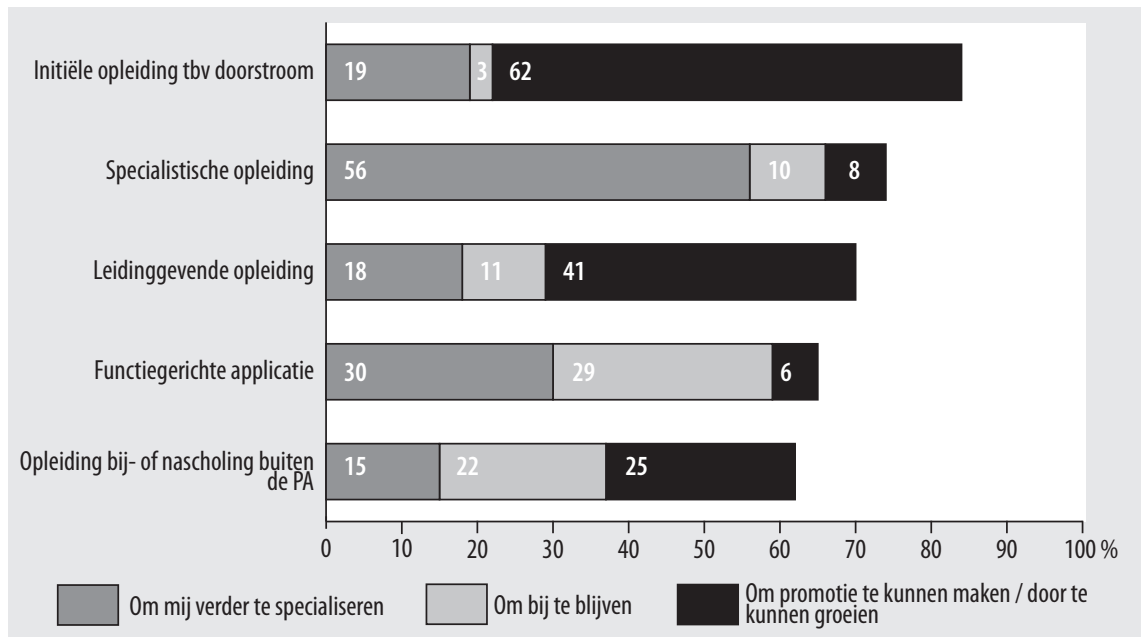

Bron: ROA enquête onder politiemensen

Noot: Omdat de andere redenen uit Figuur 3.8 hier buitenbeschouwing zijn gelaten, tellen de percentages binnen de leeftijdsgroepen niet op tot 100 . 
Figuur 3.II laat zien dat hoe hoger de rang is, hoe minder vaak er een vervolgopleiding is gevolgd om verder te specialiseren. Daarnaast toont de figuur dat hoe hoger de rang is, des te vaker er een vervolgopleiding is gevolgd om een tekort aan kennis en vaardigheden weg te werken. Dit zou ermee te maken kunnen hebben dat de gemiddelde leeftijd hoger is binnen de hogere rangen. De hoofdagenten geven het minst vaak aan een vervolgopleiding te hebben gevolgd om bij te blijven. Daarentegen geven ze relatief vaak aan dat ze een vervolgopleiding hebben gevolgd om zich verder te specialiseren of om binnen een ander politieonderdeel aan de slag te kunnen (I2\%). Inspecteurs en de groep 'operationeel overigen' geven relatief vaak aan dat ze een vervolgopleiding hebben gevolgd om bij te blijven.

Figuur 3.11

Belangrijkste reden voor gevolgde vervolgopleiding per rang

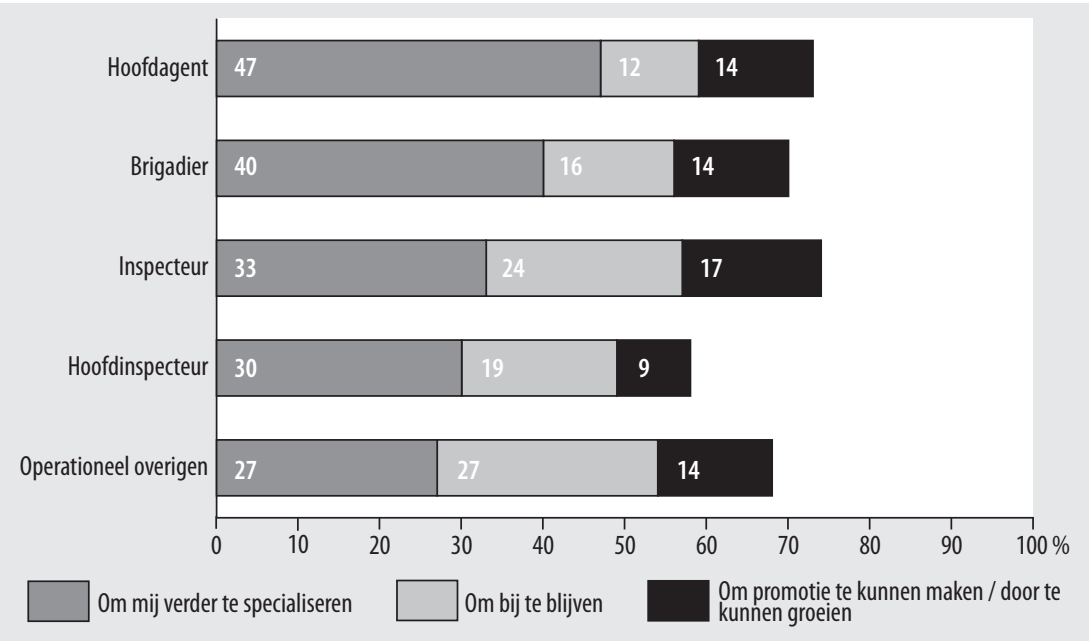

Bron: ROA enquête onder politiemensen

Noot: Omdat de andere redenen uit Figuur 3.8 hier buitenbeschouwing zijn gelaten, tellen de percentages binnen de leeftijdsgroepen niet op tot 100.

\section{Domein}

In Figuur 3.I2 wordt per domein aangegeven wat de hoofdreden van politiemensen was om aan hun laatst gevolgde vervolgopleiding deel te nemen. 
Figuur 3.12

Belangrijkste reden voor gevolgde vervolgopleiding per domein

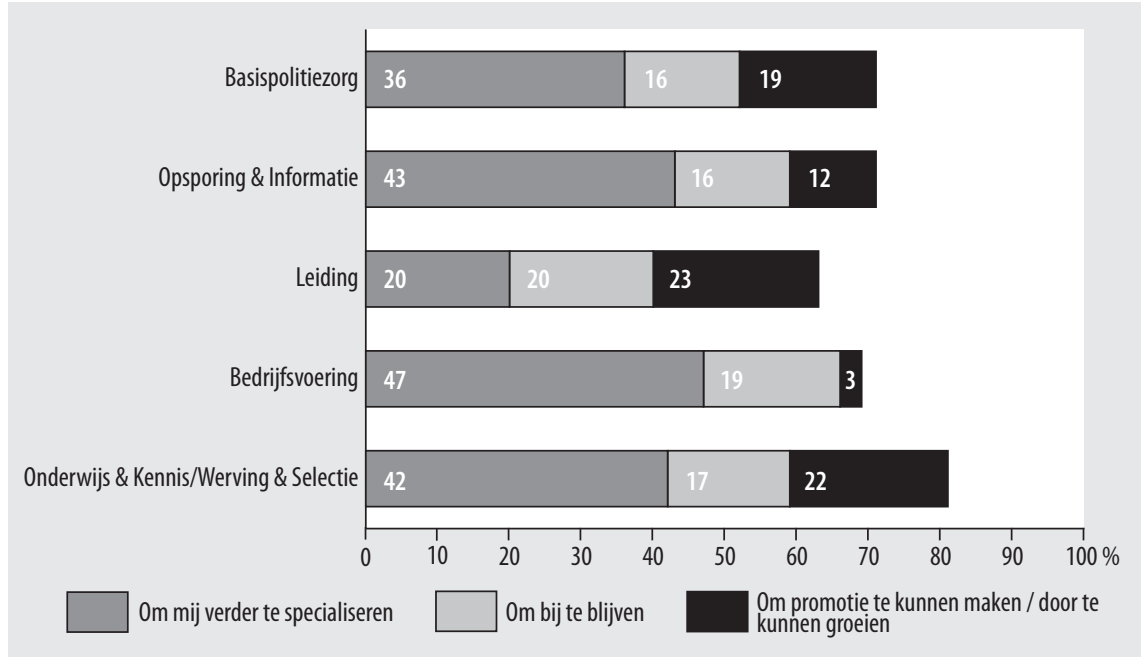

Bron: ROA enquête onder politiemensen

Noot: Omdat de andere redenen uit Figuur 3.8 hier buitenbeschouwing zijn gelaten, tellen de percentages binnen de leeftijdsgroepen niet op tot 100 .

Respondenten die werkzaam zijn in de domeinen 'bedrijfsvoering', 'opsporing \& informatie' en 'onderwijs \& kennis/werving \& selectie' hebben relatief vaak een vervolgopleiding gevolgd om zich verder te specialiseren. In het domein bedrijfsvoering zijn relatief weinig medewerkers die een vervolgopleiding hebben gevolgd om promotie te kunnen maken of door te kunnen groeien. De respondenten uit het domein leiding hebben relatief vaak een vervolgopleiding gevolgd om promotie te kunnen maken of om door te kunnen groeien, maar hebben ten opzichte van respondenten in andere domeinen relatief weinig opleidingen gevolgd om zich verder te specialiseren.

\section{5 (Gedeeltelijke) zelfmelders en niet-zelfmelders}

In deze paragraaf wordt onderzocht in hoeverre politiemensen zelfmelder zijn geweest bij het aanvragen en volgen van de meest recent gevolgde vervolgopleiding. Dat wil zeggen, in hoeverre zij zelf initiatief hebben genomen, eigen tijd hebben geïnvesteerd en eigen geld hebben geïnvesteerd ten aanzien van de opleiding. Dit kan een indicatie geven van, of verklaring bieden voor, de bereidheid tot zelfmelden in de toekomst.

Aan de respondenten is gevraagd bij wie het initiatief lag om de laatste vervolgopleiding te volgen (bij zichzelf, de leidinggevende of beide), wie deze laatste vervolgopleiding heeft betaald (zij zelf, de werkgever of beide) en of deze vervolgopleiding tijdens werktijd, in de vrije tijd of gedeeltelijk tijdens werktijd en gedeeltelijk in de vrije tijd 
is gevolgd. Op basis hiervan kunnen we bekijken hoeveel procent een volledige en hoeveel procent een gedeeltelijke zelfmelder is. Voor de gehanteerde definities van volledige en gedeeltelijke zelfmelders, zie Tekstbox 3.2.

\section{Tekstbox 3.2 Definitie volledige en gedeeltelijke zelfmelder}

Volledige zelfmelder is iemand die zowel geheel op eigen initiatief, als geheel door middel van eigen financiering, als geheel in eigen tijd een vervolgopleiding heeft gevolgd.

Gedeeltelijk zelffmelder is iemand die ofwel geheel of gedeeltelijk op eigen initiatief, en/of geheel of gedeeltelijk door middel van eigen financiering en/of geheel of gedeeltelijk in eigen tijd, een vervolgopleiding heeft gevolgd.

Niet-zelfmelder is iemand die zonder eigen initiatief, geheel onder werktijd en geheel betaald door de werkgever een opleiding heeft gevolgd.

In Figuur 3.13 is het percentage politiemensen weergegeven dat volledig, gedeeltelijk of niet-zelfmelder is geweest bij de meest recent gevolgde vervolgopleiding gedurende de afgelopen drie jaar.

\section{Figuur 3.13}

Volledig, gedeeltelijke en niet-zelfmelders

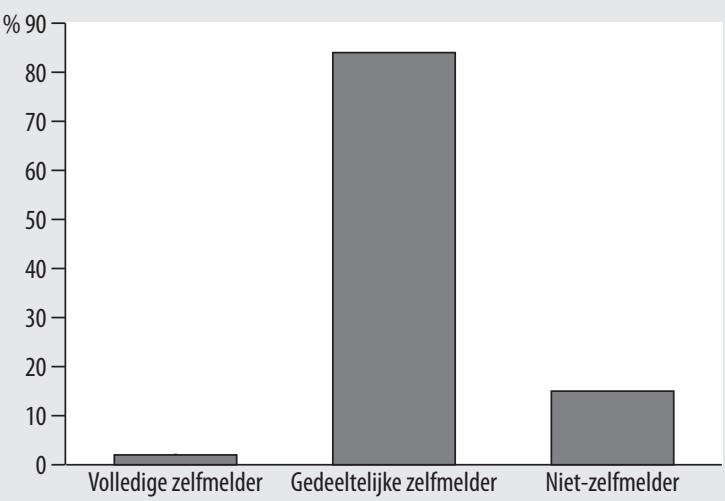

Bron: ROA enquête onder politiemensen

I\% van alle politiemensen heeft hierbij volledig het initiatief genomen, de opleiding volledig zelf betaald en heeft deze helemaal in eigen tijd gevolgd. Deze uitkomst is naar verwachting, aangezien het nooit gebruikelijk is geweest binnen de politie dat medewerkers dit allemaal zelf voor hun rekening namen. Desondanks is het percentage gedeeltelijke zelfmelders behoorlijk hoog. $84 \%$ van de ondervraagde politiemensen heeft de afgelopen drie jaar geheel of gedeeltelijk zelf het initiatief genomen, geheel of gedeeltelijk zelf voor de vervolgopleiding betaald en/of de opleiding (deels) in eigen tijd gevolgd. Het blijkt dat de groep gedeeltelijke zelfmelders vooral bestaat uit politiemensen die geheel of gedeeltelijk op eigen initiatief een vervolgopleiding hebben gevolgd, al dan niet in combinatie met een investering in eigen tijd. Een eigen 
financiële bijdrage aan de kosten van de opleiding komt slechts sporadisch voor. De resterende $15 \%$ van de politiemensen heeft de meest recente vervolgopleiding geheel onder werktijd, betaald door de organisatie en op initiatief van de leidinggevende gevolgd (niet-zelfmelders).

In Figuur 3.I4 tonen we in meer detail wie de meest recent gevolgde opleiding initieerde, wie betaalde en in wiens tijd de opleiding werd gevolg. Uit Panel A van deze figuur blijkt dat $75 \%$ van de respondenten bij de laatste vervolgopleiding in bepaalde mate eigen initiatief heeft getoond. Daarnaast heeft een aanzienlijk deel van de politiemensen de opleiding deels of geheel in eigen tijd gevolgd. Het overgrote deel (94\%) van de politiemensen volgde de opleiding geheel op kosten van de organisatie, slechts een zeer klein deel betaalde zelf (deels) mee.

\section{Figuur 3.14}

Wie initieerde en betaalde de vervolgopleiding en in wie investeerde tijd erin?

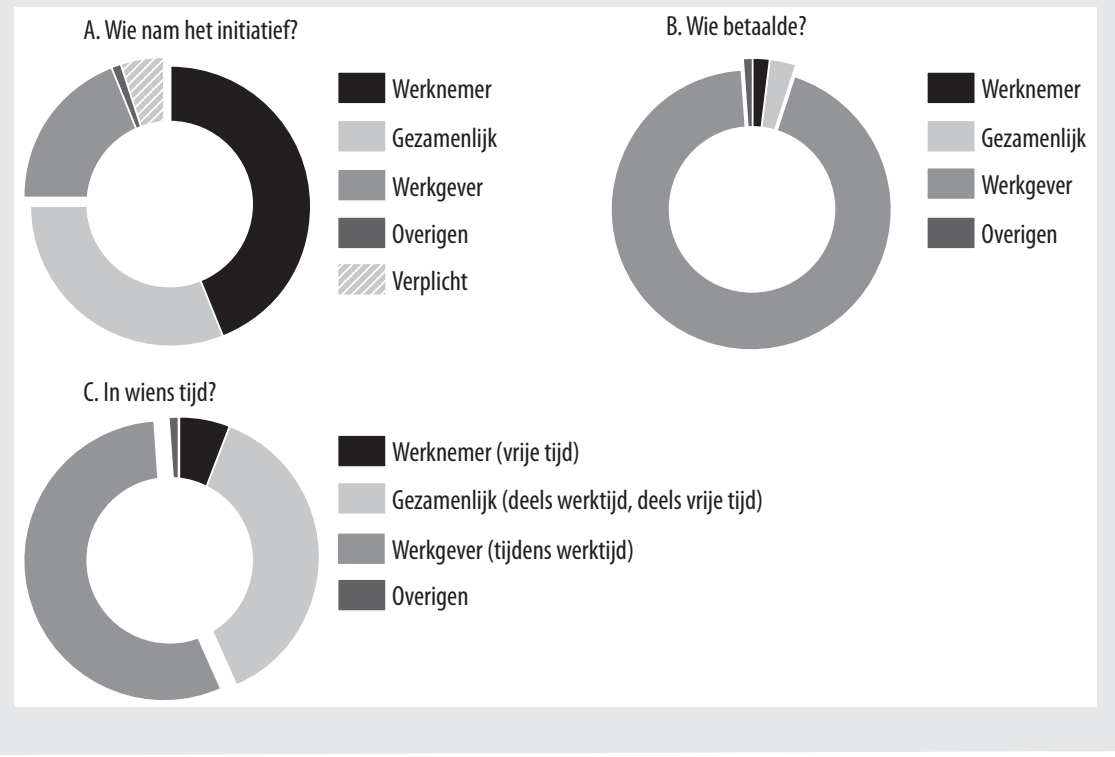

Bron: ROA enquête onder politiemensen

We bekijken nu achtereenvolgens in hoeverre persoon- en werk-gerelateerde factoren kunnen verklaren in hoeverre politiemensen zelfmelders waren. Ook kijken we in dit verband naar persoonlijkheidskenmerken. 


\section{Persoonskenmerken}

\section{Geslacht}

Tussen mannen en vrouwen waren geen verschillen in de mate van zelfmelden.

\section{Leeftijd}

Hoewel er geen grote verschillen tussen de leeftijdscategorieën zijn, zien we wel dat de jongste respondenten (25-34 jaar) relatief vaak (gedeeltelijke) zelfmelder waren. Dit komt met name doordat deze respondenten relatief vaak aangeven dat er sprake was van (gedeeltelijk) eigen initiatief en (gedeeltelijk) eigen financiële bijdrage. Daarentegen gaf deze groep relatief vaak aan dat ze de vervolgopleiding tijdens werktijd hadden gevolgd. De oudste groep respondenten (55-64 jaar) namen relatief gezien het minste initiatief voor het volgen van de meest recente vervolgopleiding. Daarbij was ook hun investering in eigen tijd laag.

\section{Werk-gerelateerde factoren}

\section{Rang}

In Figuur 3.15 is naar rang aangegeven welk percentage medewerkers de meest recente vervolgopleiding geheel of gedeeltelijk als zelfmelder heeft gevolgd. Het aandeel volledige zelfmelders is het grootst onder de hoofdinspecteurs. Ten opzichte van andere rangen blijken hoofdinspecteurs de opleiding relatief vaak volledig zelf te hebben betaald. Ook het aandeel gedeeltelijke zelfmelders is onder hoofdinspecteurs hoog met $85 \%$. Dit wordt alleen overtroffen door de inspecteurs, waar met 91\% de meeste gedeeltelijke zelfmelders waren bij de meest recente vervolgopleiding. Het aandeel niet-zelfmelders is relatief hoog onder brigadiers en hoofdagenten.

Globaal gezien neemt het aandeel volledige plus gedeeltelijke zelfmelders toe met rang. Dit komt voornamelijk doordat hoe hoger de rang, hoe vaker de opleiding deels of geheel in eigen tijd is gevolgd.

De categorie operationeel overigen is een heterogene verzamelgroep waarin onder meer buitengewoon opsporingsambtenaren en administratief technisch personeel is opgenomen. In deze groep vinden we relatief veel niet-zelfmelders $(38 \%)$ omdat deze respondenten relatief vaak een opleiding hebben gevolgd omdat het verplicht was ( $14 \%)$, of omdat de leidinggevende daartoe het initiatief nam $(38 \%)$. 


\section{Figuur 3.15}

(gedeeltelijke) zelfmelders en niet-zelfmelders per rang

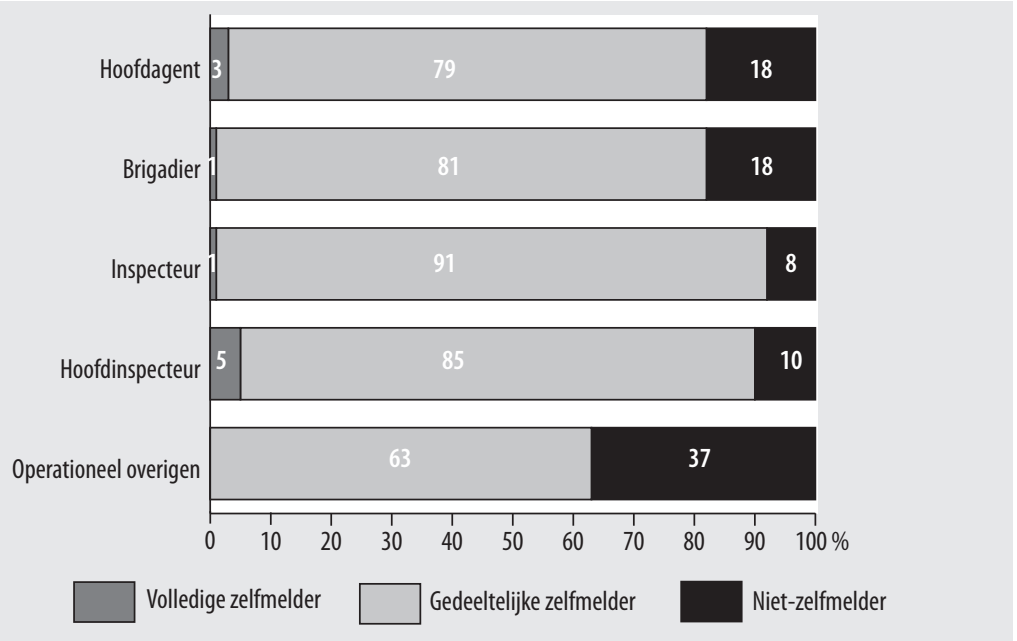

Bron: ROA enquête onder politiemensen

\section{Domein}

Binnen welk domein we relatief de meeste zelfmelders vinden is te zien in Figuur 3.I6. We zien dat er relatief weinig niet-zelfmelders zijn onder de medewerkers werkzaam in de domeinen 'leiding', 'bedrijfsvoering' en 'onderwijs \& kennis/werving \& selectie'. Andersom geredeneerd betekent dit dat de $15 \%$ niet-zelfmelders van het totaal met name wordt gedreven door de domeinen 'basispolitiezorg' en 'opsporing $\&$ informatie'.

Binnen het domein 'leiding' hebben de respondenten relatief vaak zelf het initiatief genomen voor het volgen van de vervolgopleiding (52\%) en hebben ze de vervolgopleiding relatief vaak gedeeltelijk tijdens werktijd en gedeeltelijk in de eigen tijd gevolgd (49\%).

De respondenten binnen het domein 'bedrijfsvoering' hebben relatief vaak zelf het initiatief genomen (59\%) en de opleiding volledig buiten werktijd gevolgd (19\%). Ook binnen het domein 'onderwijs \& kennis/werving \& selectie' is er relatief vaak eigen initiatief getoond ( $58 \%)$. Daarnaast zijn de vervolgopleidingen door de respondenten binnen dit domein relatief vaak volledig zelf betaald (8\%). Dit zal ermee te maken hebben dat deze medewerkers relatief vaak een opleiding, bij- of nascholing buiten de Politieacademie volgen. 


\section{Figuur 3.16}

(gedeeltelijke) zelfmelders en niet-zelfmelders per domein

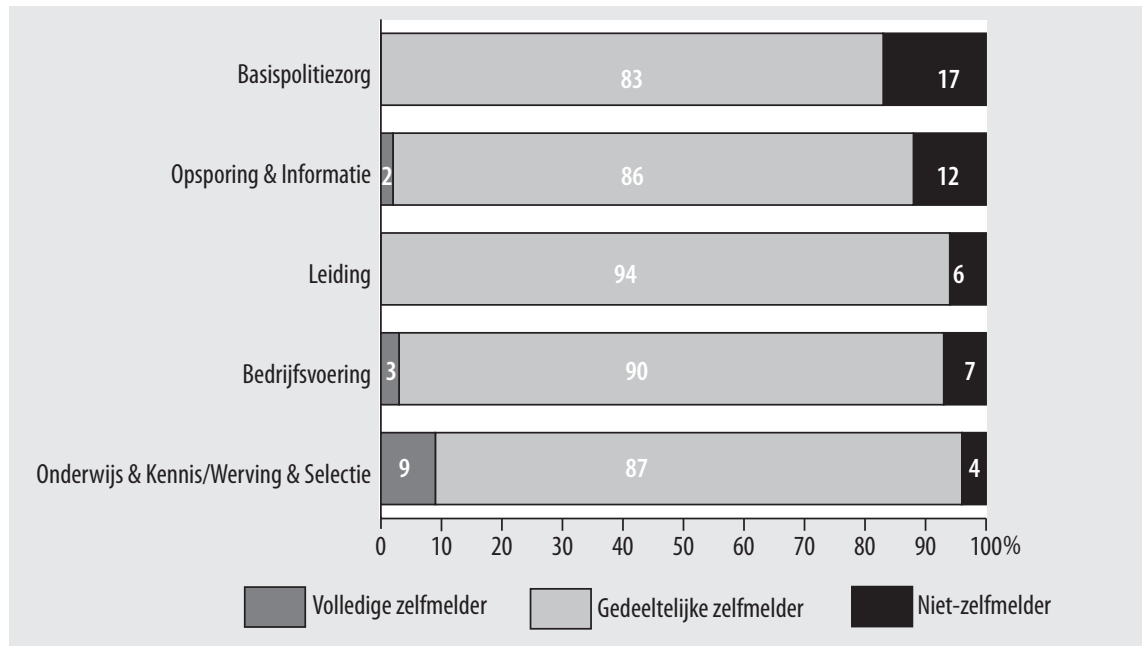

Bron: ROA enquête onder politiemensen

\section{Persoonlijkheidskenmerken}

In Bijlage B analyseren we of persoonlijkheidskenmerken van invloed zijn geweest in de mate waarin medewerkers bij hun laatst gevolgde vervolgopleiding een (gedeeltelijk) zelfmelder waren. De enige significante resultaten blijken te zijn dat politiemensen die het leuk vinden om te leren en politiemensen die zich in hoge mate verantwoordelijk voelen voor hun eigen kennis en vaardigheden, vaker (gedeeltelijk) zelfmelder zijn geweest. 



\section{Verwachte deelname aan vervolg- opleidingen en bereidheid tot eigen initiatief, eigen betaling en leren in eigen tijd}

Bijna $70 \%$ van alle politiemensen verwacht binnen vijf jaar een vervolgopleiding te gaan volgen. Het blijkt hier met name te gaan om de relatief jonge politiemensen, en om politiemensen die de afgelopen drie jaar ook al een vervolgopleiding gevolgd hebben. Bovendien schatten politiemensen die het leuk vinden om nieuwe dingen te leren de kans hoger in dat zij ook daadwerkelijk binnen vijf jaar een vervolgopleiding gaan volgen. Terwijl loopbaanwensen niet bepalend blijken te zijn voor de verwachte deelname aan vervolgopleidingen, is dit wel het geval voor loopbaankansen. Zij die verwachten binnen vijf jaar een baan buiten de politie te hebben of een specialistische functie te gaan vervullen, schatten de kans dat zij de komende vijfjaar een vervolgopleiding gaan volgen gemiddeld hoger in. Bij ongeveer $70 \%$ van de politiemensen die denken een vervolgopleiding te gaan volgen, betreft het niet-verplichte functiegerichte applicaties of specialistische opleidingen. De andere typen vervolgopleidingen zoals leidinggevende opleidingen en opleidingen buiten de Politieacademie zijn minder populair. Hoewel de meeste politiemensen bereid blijken te zijn zelf het initiatief te nemen voor het volgen van een vervolgopleiding de komende vijf jaar, is de bereidheid tot het (gedeeltelijk) zelf betalen van de opleidingen en de bereidheid de opleiding (deels) buiten werktijd te volgen beperkt tot zeer beperkt. Hoewel slechts 3\% van alle politiemensen die van plan zijn de komende vijfjaar een vervolgopleiding te gaan volgen een volledige zelfmelder lijkt te worden, verwacht 95\% gedeeltelijk zelf te melden. 


\subsection{Inleiding}

In Hoofdstuk 3 is de huidige deelname aan politieonderwijs besproken. Een belangrijke boodschap uit dit hoofdstuk is dat $68 \%$ van de politiemensen de afgelopen drie jaar een vervolgopleiding heeft gevolgd. De twee meest voorkomende vervolgopleidingen zijn een specialistische opleiding en een functiegerichte applicatie. In Hoofdstuk 4 gaan we in op de vraag of politiemensen van plan zijn de komende vijf jaar aan (nog) een vervolgopleiding deel te nemen. We zullen bekijken welke politiemensen van plan zijn (nog) een vervolgopleiding te gaan volgen (paragraaf 4.2). Ook bespreken we om welke vervolgopleidingen het over het algemeen gaat (paragraaf 4.3) en de redenen waarom politiemensen (nog) een vervolgopleiding zouden willen volgen (paragraaf 4.4). Als laatste bekijken we in hoeverre men onder de huidige omstandigheden bereid is zelf het initiatief voor het volgen van een vervolgopleiding te nemen, zelf te betalen voor de vervolgopleiding en de vervolgopleiding in eigen tijd te volgen (paragraaf 4.5 ).

\subsection{Wie wil de komende jaren aan een vervolgopleiding deelnemen?}

Om inzicht te krijgen in de vraag of politiemensen de komende vijf jaar aan een vervolgopleiding zouden willen deelnemen, hebben we allereerst een duidelijke definitie van een vervolgopleiding aan de respondenten van de enquête voorgelegd. Deze is reeds vermeld in Tekstbox 2.I.

Vervolgens hebben we de respondenten gevraagd of zij denken de komende vijf jaar aan een vervolgopleiding deel te nemen. Het blijkt dat iets meer dan 30\% van de respondenten verwacht de komende vijf jaar geen vervolgopleiding te volgen. De andere krap $70 \%$ denkt dus wel een vervolgopleiding te gaan volgen binnen vijf jaar. ${ }^{23}$

We gaan nu kort in op de vraag wie deze politiemensen zijn. Allereerst bekijken we een aantal persoonskenmerken, zoals leeftijd en geslacht. Daarnaast bekijken we ook een aantal werk-gerelateerde factoren zoals rang, domein en eerdere deelname aan vervolgopleidingen. Als laatste bekijken we een aantal persoonlijkheids-kenmerken zoals risicovoorkeur en reciprociteit (wederkerigheid). ${ }^{24}$.We sluiten deze paragraaf af met een overzicht van multivariate analyses waarin we duidelijk kunnen zien welke van de bovengenoemde factoren het meest bepalend zijn voor de verwachting binnen vijf jaar een vervolgopleiding te volgen.

23. Om welke vervolgopleiding het gaat zien we in paragraaf 4.3 .

24. Zie Bijlage B voor een uitleg over het begrip reciprociteit. 


\section{Persoonskenmerken}

\section{Geslacht}

Allereerst gaan we in op de vraag of er een verschil is in de verwachte deelname aan vervolgopleidingen tussen mannen en vrouwen. Hoewel in Hoofdstuk 3 bleek dat er geen verschillen zijn tussen mannen en vrouwen in de vervolgopleidingsdeelname in de afgelopen drie jaar, blijkt er wel een significant verschil te zijn in de verwachte deelname aan vervolgopleidingen. Terwijl meer dan $75 \%$ van de vrouwen verwacht binnen vijf jaar een vervolgopleiding te gaan volgen, is dit $67 \%$ voor mannen.

\section{Leeftijd}

Naast het geslacht, blijkt ook de leeftijd van politiemensen een rol te spelen in de verwachte deelname aan vervolgopleidingen. Dit zien we in Figuur 4.I. ${ }^{25}$ In lijn met de theorie van het menselijk kapitaal zien we dat naarmate men ouder wordt, de verwachting dat men aan een vervolgopleiding zal deelnemen afneemt. Zowel werknemers als werkgevers hebben namelijk minder baat bij het investeren in werknemers naarmate deze dichter bij de pensioengerechtigde leeftijd komen (Nelen \& De Grip 2009). ${ }^{26}$ Terwijl ongeveer $80 \%$ van de politiemensen in de leeftijdscategorie 40-55 verwacht binnen vijf jaar een vervolgopleiding te gaan volgen, neemt dit percentage hierna duidelijk af. $27 \%$ van de politiemensen van zestigjarige leeftijd denkt binnen vijf jaar een vervolgopleiding te gaan volgen. Hoewel dit percentage duidelijk lager is dan hun jongere collega's, is dit percentage toch nog redelijk hoog in vergelijking met Nederland in het geheel. ${ }^{27}$ Dit zou te maken kunnen hebben met een verandering in het takenpakket van relatief oudere politiemensen waardoor een vervolgopleiding nodig is.

25. We hebben leeftijden weggelaten met minder dan 20 personen. Er hebben betrekkelijk weinig jonge politiemensen deelgenomen aan de enquête en daardoor zijn in de figuur geen gemiddeldes weergegeven voor politiemensen jonger dan 40 jaar.

26. A. Nelen and A. de Grip (2009). 'Why do part-time workers invest less in human capital than fulltimers?', Labour, 2009, vol. 23(sI), pp. 6I-83.

27. Gebaseerd op het OSA aanbodspanel (1985-2006) is de gemiddelde trainingsdeelname onder zestigjarige werknemers in Nederland onder de I0\%. Binnen de metalelektro geldt dat van de groep 60+ niet wordt verwacht dat zij nog aan vervolgopleidingen deelnemen omdat zij op korte termijn met pensioen gaan. 
Figuur 4.1

Verwachte deelname aan vervolgopleidingen naar leeftijd

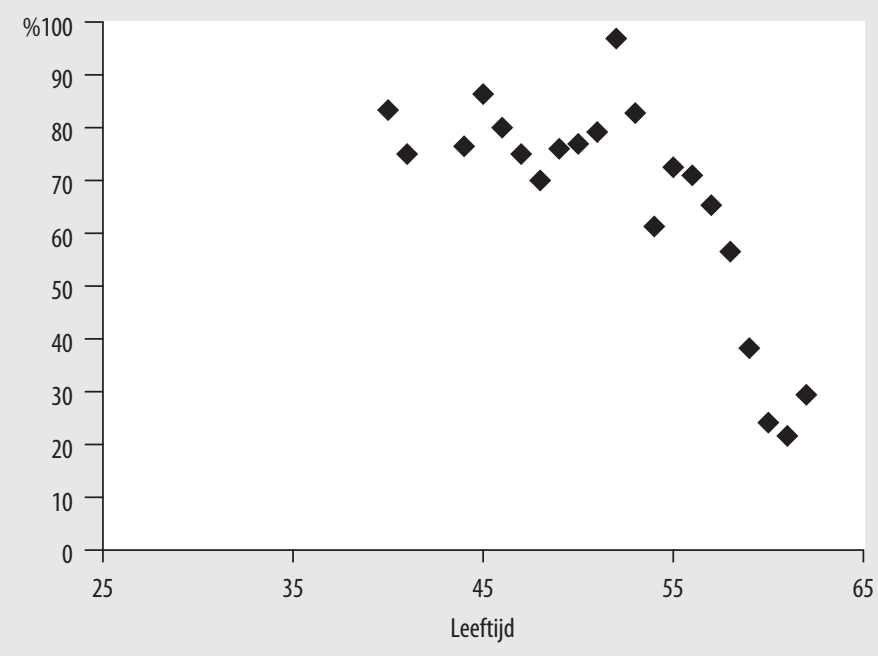

Bron: ROA enquête onder politiemensen

\section{Werk-gerelateerde factoren}

Rang

Vervolgens bekijken we of er een onderscheid is tussen de verwachte deelname aan vervolgopleiding voor politiemensen met verschillende rangen. In Figuur 4.2 is dit weergegeven. We zien dat er over het algemeen een afnemende relatie bestaat tussen de rang en de verwachte deelname aan vervolgopleidingen. ${ }^{28}$ Aspiranten geven het meest aan te verwachten dat zij de komende vijf jaar een vervolgopleiding gaan volgen. Ongeveer negen van de tien aspiranten verwacht de komende vijf jaar aan een vervolgopleiding deel te nemen. Ook agenten geven vaak aan dat zij verwachten de komende vijf jaar een vervolgopleiding te gaan volgen (89\%). Het percentage hoofdagenten dat verwacht de komende vijf jaar aan een vervolgopleiding deel te nemen ligt iets onder de $80 \%$. Toch is het onderscheid tussen aan de ene kant aspiranten, agenten en hoofdagenten, en aan de andere kant brigadiers, inspecteurs en hoofdinspecteurs groter. De verwachte deelname aan vervolgopleidingen is voor deze laatste drie rangen duidelijk lager. Toch geldt ook voor deze drie categorieën politiemensen dat minimaal 50\% verwacht binnen vijf jaar aan een vervolgopleiding deel te nemen. Iets meer dan zes op de tien politiemensen met de rang 'operationeel overig' denkt binnen vijf jaar een vervolgopleiding te volgen. Het is opvallend dat de verwachte deelname aan vervolgopleidingen onder politiemensen met een lage rang hoger is dan

28. Voor politiemensen met de rang 'operationeel overig' is niet duidelijk om wat voor functieniveau het gaat. Dit is wel duidelijk voor de andere rangen. 
onder politiemensen met een hoge rang, omdat we in Hoofdstuk 3 gevonden hebben dat deelname aan vervolgopleidingen gedurende de afgelopen drie jaar juist relatief hoger is onder de politiemensen met een relatief hoge rang. Hoewel dit in eerste instantie contra-intuïtief lijkt, hoeft dit niet zo te zijn. Het lijkt er eerder op dat voor de lagere rangen geldt dat men eerst een aantal jaren ervaring nodig heeft voordat men een vervolgopleiding volgt. De observatie dat politiemensen met een hoge rang de komende jaren minder vaak verwachten een vervolgopleiding te gaan volgen, kan ook met hun leeftijd te maken hebben. ${ }^{29}$

\section{Figuur 4.2}

Verwachte deelname aan vervolgopleidingen per rang

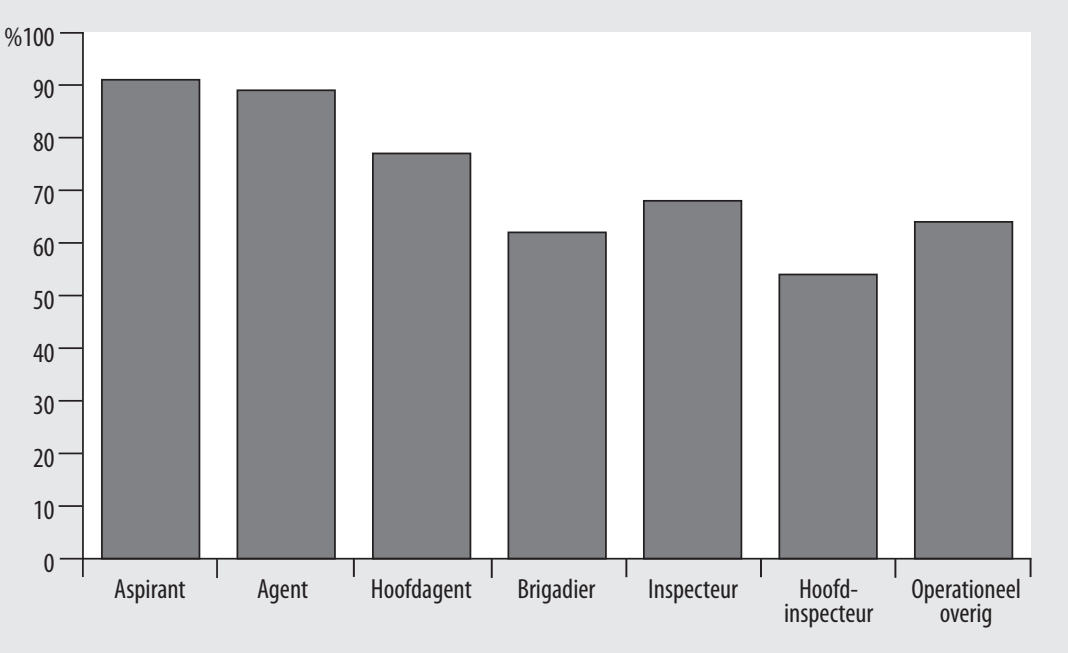

Bron: ROA enquête onder politiemensen

\section{Domein}

Er blijkt niet alleen een onderscheid te zijn naar verwachte deelname aan vervolgopleiding per rang, maar ook per domein. In Figuur 4.3 is dit onderscheid weergegeven..$^{30}$ We zien dat binnen het domein 'opsporing en informatie' het percentage medewerkers dat verwacht een vervolgopleiding te gaan volgen binnen vijf jaar het grootst is $(73 \%)$. Binnen de domeinen 'basispolitiezorg' en 'onderwijs \& kennis, werving en selectie' ligt het percentage medewerkers dat binnen vijf jaar een vervolgopleiding denkt te gaan volgen iets onder de 70 . Politiemensen die behoren tot het domein 'bedrijfsvoering' geven duidelijk minder vaak aan dat zij de komende vijf jaar een vervolgopleiding denken te gaan volgen $(46 \%)$.

29. Terwijl de gemiddelde leeftijd van surveillanten, agenten en hoofdagenten onder de 50 ligt, is de gemiddelde leeftijd onder de politiemensen met een hogere rang boven de 50.

30. Het aantal respondenten voor de domeinen 'intake en service' en 'leiding' is onder de 20. Als gevolg van dit kleine aantal observaties, zijn deze domeinen niet weergegeven in Figuur 3.2. 
Figuur 4.3

Verwachte deelname aan vervolgopleidingen per domein

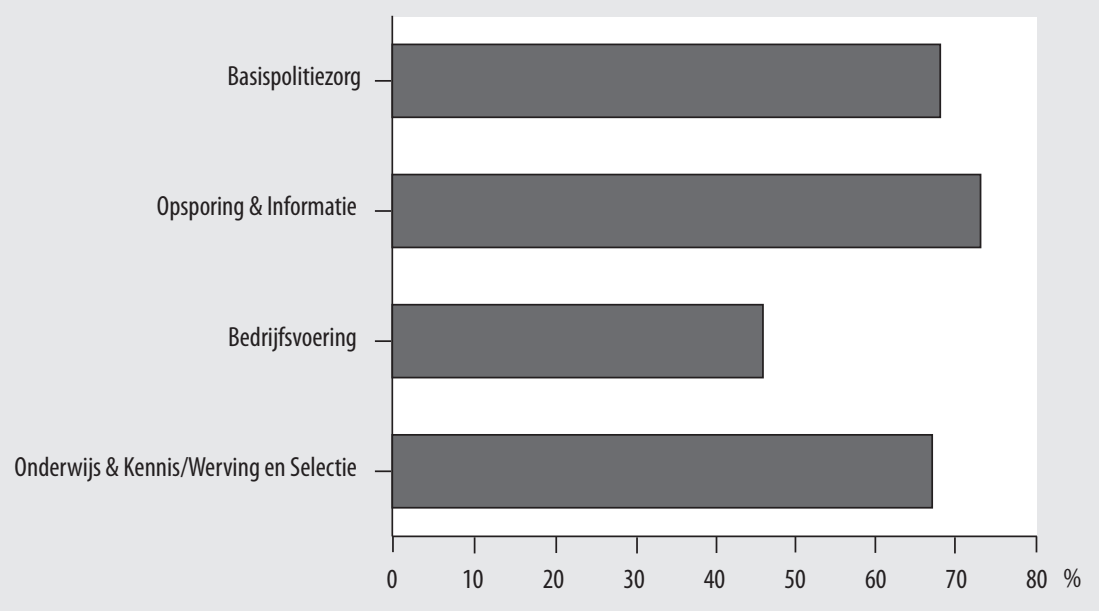

Bron: ROA enquête onder politiemensen

\section{Vervolgopleidingsdeelname in afgelopen 3 jaar}

Het is ook interessant om te weten of deelname aan vervolgopleidingen in de afgelopen drie jaar gerelateerd is aan de verwachte deelname aan vervolgopleidingen in de komende vijf jaar. Het blijkt dat er inderdaad een relatie bestaat tussen afgelopen deelname en verwachte deelname in de nabije toekomst. Terwijl $74 \%$ van de politiemensen die de afgelopen jaren al een vervolgopleiding heeft gevolgd de komende vijf jaar weer een vervolgopleiding denkt te gaan volgen, is dit percentage met $58 \%$ duidelijk lager voor diegenen die de afgelopen drie jaar nog geen vervolgopleiding hebben gevolgd.

Hieruit maken we op dat het niet zo lijkt te zijn dat het binnen de politie gebruikelijk is om, in een bepaalde periode, slechts één vervolgopleiding te volgen. Ook wijst dit niet op scholingsmoeheid. Een hoofd-opleidingen bij een grote zorginstelling, waar net als bij de politie al veel wordt geschoold omdat de sector en het vak veranderen en er veel verplichte hercertificeringen plaatsvinden, noemt scholingsmoeheid als potentiële remmende factor ten aanzien van additionele scholing op eigen initiatief. Binnen de politie lijkt dit dus niet het geval.

Het lijkt er eerder op dat learning begets learning. Dit wil zeggen, dat leren verder leren stimuleert. ${ }^{3 i}$ Dit zou te maken kunnen hebben met persoonlijkheidskenmerken. Zo

3I. Een andere vorm van learning begets learning is gevonden onder Nederlandse werknemers, waar deelname aan cursussen en informeel leren op de werkvloer vaak hand in hand blijken te gaan (Borghans et al. 20II). 
is het te verwachten dat politiemensen die graag leren of een duidelijk beeld hebben van hun toekomstige loopbaan, meer dan eens aan een vervolgopleiding deelnemen.

\section{Persoonlijkheidskenmerken}

In Bijlage $\mathrm{C}$ analyseren we of persoonlijkheidskenmerken van invloed zijn op de intentie om in de komende vijf jaar een vervolgopleiding te willen volgen. De persoonlijkheidskenmerken 'het leuk vinden om te leren' en 'jezelf doelen stellen' blijken positief en significant gerelateerd aan de verwachting om in de komende vijf jaar een vervolgopleiding te gaan volgen. Andere persoonlijkheidskenmerken zijn niet significant van invloed.

\section{Determinanten van verwachte deelname aan vervolgopleidingen}

Tot nu toe hebben we gezien dat de verwachte deelname aan vervolgopleidingen verschilt voor politiemensen met verschillende werk-gerelateerde factoren en persoonskenmerken. Echter, de observatie dat vrouwen vaker verwachten aan een vervolgopleiding deel te nemen, kan ook het gevolg zijn van het domein waarin zij werken (bijvoorbeeld: vrouwen werken veel minder vaak in het domein bedrijfsvoering, waar de verwachte deelname aan vervolgopleidingen lager is dan in de andere domeinen). Mocht dit het geval zijn, dan hangt de verwachte deelname aan vervolgopleidingen dus niet af van iemands geslacht per se maar van het domein waarin hij/zij werkzaam is. Om hier meer duidelijkheid in te krijgen, rapporteren we hier een aantal multivariate analyses. Dit zijn analyses waarin de verwachte deelname aan een vervolgopleiding binnen vijf jaar niet één op één aan de hierboven beschreven kenmerken wordt gerelateerd, maar waarin meerdere kenmerken tegelijk worden bekeken. Hierdoor krijgen we een beter inzicht in de determinanten van de verwachte deelname aan vervolgopleidingen. De resultaten zijn opgenomen in Tabel 4.2. 
Tabel 4.2

Determinanten van verwachte deelname aan vervolgopleidingen

\begin{tabular}{|c|c|c|}
\hline \multicolumn{3}{|c|}{ Afhankelijke variabele: verwachte deelname aan vervolgopleiding (ja/nee) } \\
\hline & (kolom 1) & (kolom 2) \\
\hline & correlaties & $\begin{array}{l}\text { multivariate } \\
\text { relatie }\end{array}$ \\
\hline \multicolumn{3}{|l|}{ Persoonskenmerken } \\
\hline Man (vrouwen zijn referentie) & - & 0 \\
\hline Leeftijd & - & + \\
\hline Leeftijd kwadraat* & n.v.t. & - \\
\hline \multicolumn{3}{|l|}{ Werk-gerelateerde factoren } \\
\hline Rang & - & 0 \\
\hline Domein & $\begin{array}{l}\text { Opsporing \& } \\
\text { informatie + }\end{array}$ & $\begin{array}{l}\text { Opsporing \& } \\
\text { informatie + }\end{array}$ \\
\hline Vervolgopleiding laatste drie jaar & + & + \\
\hline \multicolumn{3}{|l|}{ Persoonlijkheidskenmerken } \\
\hline Risicovoorkeur & 0 & 0 \\
\hline Positieve reciprociteit & 0 & 0 \\
\hline Negatieve reciprociteit & 0 & 0 \\
\hline Tijdsvoorkeur & 0 & 0 \\
\hline Verantwoordelijkheid voor kennis & 0 & 0 \\
\hline Leuk om te leren & + & + \\
\hline Doelen stellen, duidelijk beeld toekomst & + & 0 \\
\hline \multicolumn{3}{|c|}{$\begin{array}{l}\text { Bron: ROA enquête onder politiemensen } \\
\text { * Leeftijd kwadraat staat gelijk aan leeftijd*leeftijd en geeft aan dat de positieve relatie tussen } \\
\text { verwachte deelname aan vervolgopleidingen en leeftijd geleidelijk afneemt en na een kantelpunt } \\
\text { (wat ligt bij } 37 \text { jaar) omslaat in een negatieve relatie tussen leeftijd en verwachte deelname aan } \\
\text { vervolgopleidingen. }\end{array}$} \\
\hline
\end{tabular}

In Kolom (I) is een overzicht gegeven van de correlatie tussen de verschillende persoon-, werk- en persoonlijkheidskenmerken aan de ene kant en de verwachte deelname aan een vervolgopleiding aan de andere kant. Het betreft hier dus één-op-één correlaties. Deze correlaties geven de statistische testen achter de eerder in dit hoofdstuk beschreven figuren weer. In Kolom (2) vinden we wederom de relaties tussen de verschillende factoren aan de ene kant en de verwachte deelname aan vervolgopleidingen aan de andere kant, maar ditmaal gecontroleerd voor de andere factoren. Rekening houdend met iemands leeftijd, werk-gerelateerde factoren en persoonlijkheidskenmerken, zien we nu geen significante relatie meer tussen de verwachting dat iemand de komende vijf jaar aan een vervolgopleiding gaat deelnemen en iemands geslacht. Mannen en vrouwen hebben dus, gecontroleerd voor alle genoemde factoren, dezelfde verwachtingen met betrekking tot hun deelname aan vervolgopleidingen de komende vijf jaar. ${ }^{32}$ Dit is in lijn met de bevindingen voor Nederland in het geheel (Borghans et al. 20II). Leeftijd is echter nog steeds van belang. Uit de multiva-

32. Aanvullende analyses laten bovendien zien dat de kans die iemand in schat om de komende vijf jaar (g)een vervolgopleiding te gaan volgen niet significant gerelateerd is aan het hebben van thuiswonende kinderen. 
riate analyses blijkt bovendien dat de kans op het volgen van een vervolgopleiding de komende vijf jaar positief samenhangt met de observatie of iemand de afgelopen drie jaar al een vervolgopleiding gevolgd heeft. Politiemensen werkzaam in het domein 'opsporing en informatie' geven ook aan vaker van plan te zijn een vervolgopleiding te gaan volgen dan medewerkers in andere domeinen. Iemands rang is niet langer van belang nu er rekening gehouden wordt met andere factoren. De vier economische voorkeuren - risicovoorkeur, positieve en negatieve reciprociteit (wederkerigheid) ${ }^{33}$ en tijdsvoorkeur - blijken geen significante rol te spelen voor de verwachting om binnen vijf jaar een vervolgopleiding te gaan doen. Dit is anders voor de mate waarin iemand het leuk vindt om te leren. Ongeacht de leeftijd geldt dat hoe leuker iemand het vindt om nieuwe dingen te leren, hoe hoger de verwachting dat binnen vijf jaar aan een vervolgopleiding wordt deelgenomen.

\subsection{In welke vervolgopleiding hebben politiemensen interesse?}

We hebben niet-leidinggevende politiemensen niet alleen gevraagd of zij denken binnen vijf jaar een vervolgopleiding te gaan volgen, maar ook concreet wat voor soort vervolgopleiding zij denken te gaan volgen:

- Een initiële opleiding ten behoeve van doorstroom

- Een specialistische opleiding

- Een leidinggevende opleiding

- Een functiegerichte applicatie

- Een opleiding buiten de Politieacademie (bijvoorbeeld bedrijfskunde of criminologie).

In Figuur 4.4 zijn de antwoorden weergegeven op de vraag welk type vervolgopleiding politiemensen denken te gaan volgen weergegeven. ${ }^{34}$ De meeste politiemensen verwachten een specialistische opleiding of een functiegerichte applicatie te gaan volgen. ${ }^{35} 37 \%$ van de niet-leidinggevenden geeft aan te verwachten een specialistische opleiding te gaan volgen. Ook het percentage niet-leidinggevenden dat verwacht een functiegerichte applicatie te gaan volgen is met $35 \%$ relatief hoog. Op de gedeelde derde plaats staan het volgen van een initiële opleiding ten behoeve van doorstroom en het volgen van een leidinggevende opleiding (II\%). Ongeveer $6 \%$ van de nietleidinggevenden denkt binnen vijf jaar een opleiding buiten de Politieacademie te gaan volgen.

33. Zie Bijlage B voor een uitleg over het begrip reciprociteit.

34. Politiemensen konden slechts één type vervolgopleiding aangeven.

35. Deze twee typen vervolgopleidingen zijn ook de meest genoemde vervolgopleidingen die politiemensen de afgelopen drie jaar hebben gevolgd (zie Hoofdstuk 3). 


\section{Figuur 4.4}

Verwachte deelname aan vervolgopleidingen in de komende vijf jaar

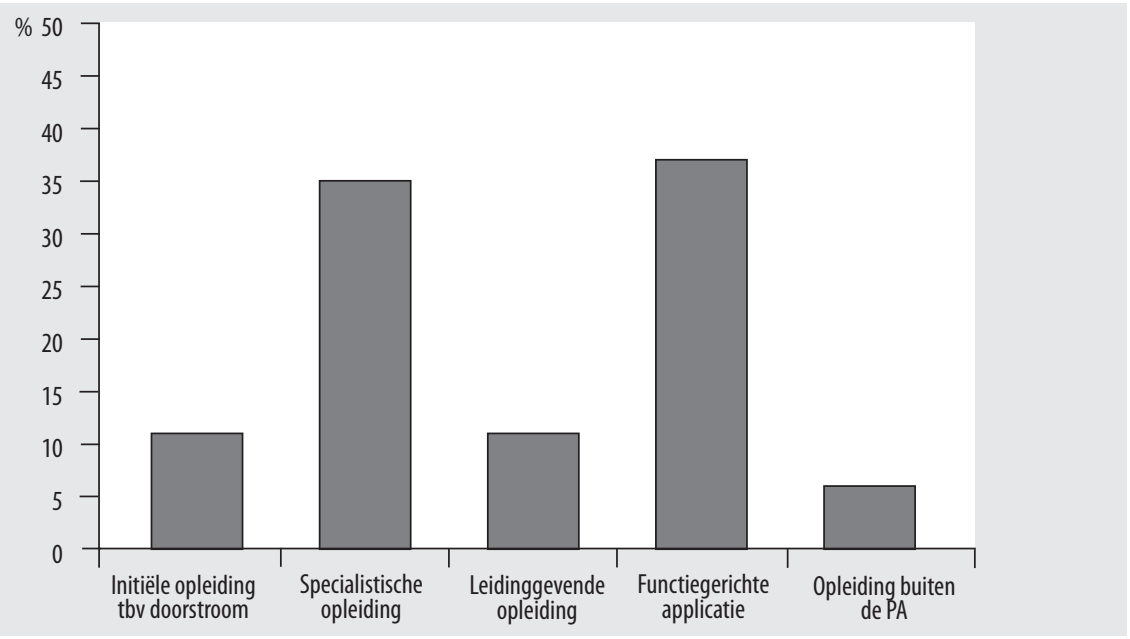

Bron: ROA enquête onder politiemensen

Omdat de functiegerichte applicaties en de specialistische opleidingen veruit het meest genoemd worden als vervolgopleidingen die men de komende vijf jaar denkt te gaan volgen, richten we ons bij de nadere analyses alleen op deze twee vervolgopleidingen. Het is namelijk niet alleen interessant om te weten wie überhaupt een vervolgopleiding denkt te gaan volgen maar ook wie welk soort vervolgopleiding wil gaan volgen. In Figuur 4.5 zien we dat vrouwen vaker denken een functiegerichte applicatie te gaan volgen dan mannen. Mannen daarentegen denken vaker een specialistische opleiding te gaan volgen dan vrouwen.

\section{Figuur 4.5}

Deelname mannen en vrouwen aan functiegerichte applicaties en specialistische opleidingen

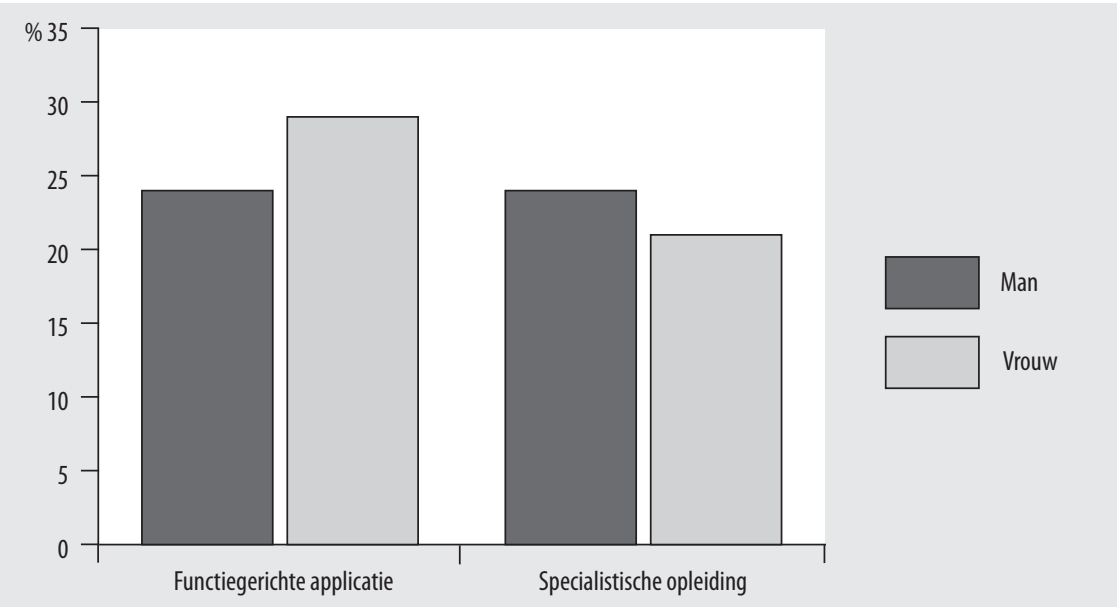

Bron: ROA enquête onder politiemensen 
Terwijl er een duidelijke negatieve relatie te zien was tussen de verwachte deelname aan vervolgopleidingen en iemands leeftijd, blijkt uit Figuur 4.6 (Panel a) dat deze relatie niet zo duidelijk is voor deelname aan functiegerichte applicaties. Hoewel ongeveer $20 \%$ van veertigjarigen denkt de komende vijf jaar een functiegerichte applicatie te volgen neemt dit percentage toe tot ongeveer 50\% onder de politiemensen van 53 jaar. Daarna neemt het percentage echter drastisch af. De waarschijnlijkheid dat iemand een specialistische opleiding gaat volgen de komende vijf jaar neemt daarentegen al af vanaf de leeftijd van 40 jaar (Panel (b)).

Figuur 4.6

Deelname aan functiegerichte applicaties en specialistische opleidingen naar leeftijd

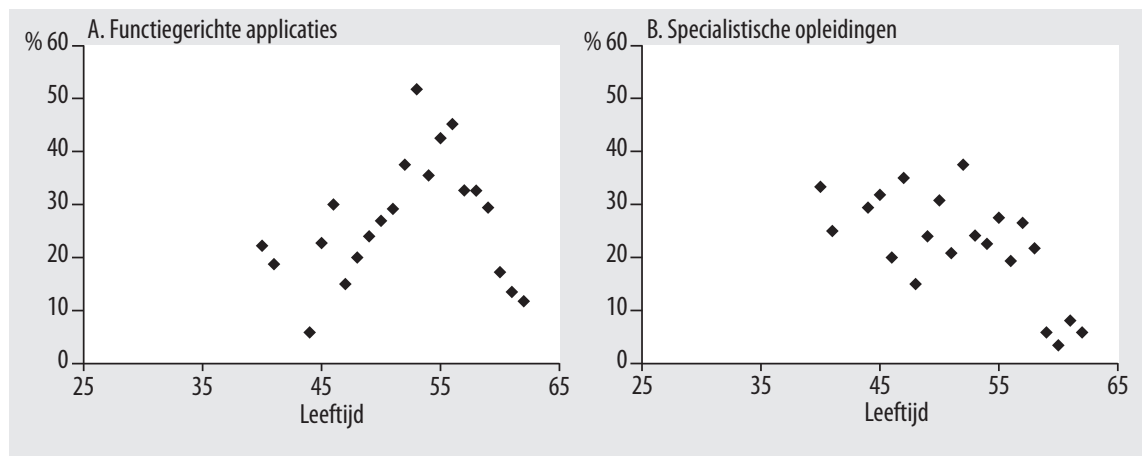

Bron: ROA enquête onder politiemensen

In Figuur 4.7 is de relatie tussen verwachte deelname aan vervolgopleidingen en de werk-gerelateerde factoren opgenomen.

In Panel (a) zien we een duidelijke relatie tussen rang en het soort vervolgopleiding dat men verwacht te gaan doen. Terwijl onder de lagere rangen - aspirant, agent en hoofdagent - de specialistische opleidingen meer in trek lijken te zijn, is dit juist niet zo voor de andere drie rangen die opgenomen zijn in de figuur. Hoewel er onder brigadiers ongeveer evenveel animo is voor functiegerichte applicaties en specialistische opleidingen, verwachten (hoofd) inspecteurs vaker een functiegerichte applicatie te volgen dan een specialistische opleiding.

In Panel (b) van Figuur 4.7 is het domein van de politiemensen opgenomen. Terwijl medewerkers binnen de domeinen 'basispolitiezorg' en 'opsporing en informatie' vaker denken een specialistische opleiding te gaan volgen, denken mensen binnen de domeinen 'bedrijfsvoering' en 'onderwijs \& kennis, werving en selectie' vaker een functiegerichte applicatie te volgen. 


\section{Figuur 4.7}

Verwachte deelname aan functiegerichte applicaties en specialistische opleidingen naar rangen en domein

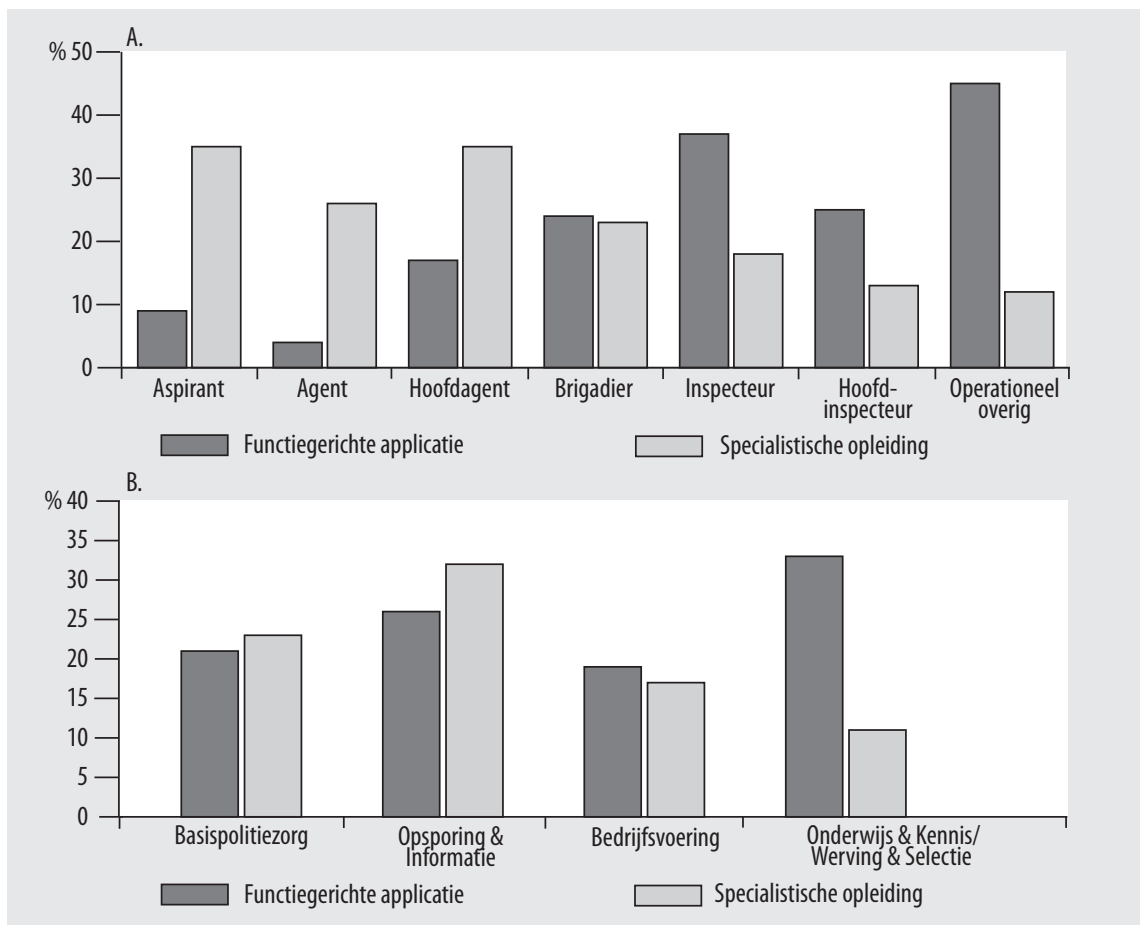

Bron: ROA enquête onder politiemensen

Zoals te verwachten is op basis van de bevindingen in paragraaf 4.2, blijken de economische voorkeuren - risicovoorkeur, reciprociteit en tijdsvoorkeur - ook niet van belang voor het soort vervolgopleiding dat men verwacht te gaan volgen. Echter, de andere drie persoonlijkheidskenmerken waarnaar we in paragraaf 4.2 gekeken hebben - verantwoordelijkheidsgevoel voor eigen kennis en vaardigheden, leuk vinden om te leren en het stellen van doelen - blijken in sommige gevallen wel te verklaren wat voor soort vervolgopleiding iemand denkt te gaan doen. ${ }^{36}$

36. Zo is uit enkelvoudige correlatie-analyses gebleken dat politiemensen die leren erg leuk vinden over het algemeen vaker kiezen voor een specialistische opleiding dan voor een functiegerichte opleiding. De mate waarin politiemensen zich verantwoordelijk voelen voor hun eigen kennis en vaardigheden is positief gecorreleerd met de keuze voor een functiegerichte opleiding. De mate waarin politiemensen een duidelijk beeld hebben van hun toekomstige loopbaan en zichzelf doelen stellen is negatief gecorreleerd met de keuze voor een functiegerichte applicatie, maar positief gecorreleerd met de keuze voor een specialistische opleiding. 


\subsection{Waarom willen politiemensen zich verder ontwikkelen?}

In deze paragraaf gaan we in op de vraag waarom politiemensen van plan zijn zich de komende vijf jaar verder te ontwikkelen? We hebben in paragraaf 4.2 en 4.3 al gezien dat sommige persoonlijkheidskenmerken, zoals leervoorkeuren, bepalend zijn of en welke vervolgopleiding iemand denkt te gaan volgen. Maar er zouden ook loopbaanontwikkelingen ten grondslag kunnen liggen aan hun verwachte deelname aan vervolgopleidingen. Achterliggende redenen van politiemensen om de komende vijf jaar al dan niet aan vervolgopleidingen deel te nemen zijn erg informatief voor de vraag of en hoe politiemensen te stimuleren zijn in hun leergedrag en hun eigen bereidheid daartoe. Daarom bespreken we in deze paragraaf een aantal loopbaanontwikkelingen in relatie tot de verwachting om aan een vervolgopleiding deel te nemen binnen vijf jaar. We onderscheiden hierbij loopbaankansen en loopbaanwensen.

\section{Deelname aan vervolgopleidingen en loopbaanperspectieven}

Loopbaanperspectieven en -wensen hangen vaak samen met de intentie om een vervolgopleiding te gaan doen. Daarom relateren we in Tabel 4.3 de verwachte deelname aan een vervolgopleiding binnen vijf jaar aan zowel de loopbaankansen die iemand voor zichzelf ziet (kolom I) als aan de loopbaanwensen (kolom 2). Voor de volledigheid zijn ook de persoon-gerelateerde en de werk-gerelateerde factoren meegenomen (zoals in Tabel 4.2).

Uit de tabel blijkt dat met name de manier waarop iemand zijn loopbaankansen inschat, van invloed is op de beslissing om de komende vijf jaar een vervolgopleiding te gaan volgen. Als mensen denken dat zij over vijf jaar een andere baan buiten de politie zullen hebben, is de kans dat zij de komende vijf jaar een vervolgopleiding denken te gaan volgen relatief groot. Ook mensen die verwachten over vijf jaar een specialistische functie te hebben, geven aan dat zij de komende vijf jaar een vervolgopleiding zullen gaan volgen. Dit wijst erop dat mensen die een baan buiten de politie of een specialistische functie denken te gaan krijgen, het nodig vinden om zich om- of bij te scholen. Daarentegen vinden we dat mensen die de kans hoog inschatten dat zij een vergelijkbare baan kunnen vinden als hun huidige baan (mocht dat nodig zijn) minder vaak van plan zijn om de komende vijf jaar een vervolgopleiding te volgen. Dit duidt erop dat zij denken een vervolgopleiding niet nodig te hebben om een vergelijkbare baan te vinden. Met andere woorden, zij verwachten dat hun kennis en vaardigheden voldoende zijn voor de baan die zij nu uitvoeren. De kans op het hebben van een leidinggevende functie blijkt niet gerelateerd te zijn aan de verwachting om de komende vijf jaar een vervolgopleiding te volgen. Dit is opvallend omdat we in Hoofdstuk 3 zagen dat leidinggevenden relatief vaak een leidinggevende opleiding hebben gevolgd. 
Tabel 4.3

Determinanten van vervolgopleidingen (inclusief loopbaan-perspectieven) ${ }^{37}$

\begin{tabular}{|c|c|c|}
\hline Afhankelijke variabele: verwach & $\begin{array}{l}\text { iding (ja/ne } \\
\text { (kolom 1) }\end{array}$ & (kolom 2) \\
\hline \multicolumn{3}{|l|}{ Persoonskenmerken } \\
\hline Man & 0 & 0 \\
\hline Leeftijd & + & 0 \\
\hline Leeftijd kwadraat & - & 0 \\
\hline \multicolumn{3}{|l|}{ Werk-gerelateerde factoren } \\
\hline Rang & 0 & 0 \\
\hline Domein & 0 & 0 \\
\hline Vervolgopleiding laatste drie jaar & + & + \\
\hline \multicolumn{3}{|l|}{ Loopbaankansen (over 5 jaar) } \\
\hline Baanverlies & 0 & \\
\hline Andere baan binnen de politie & 0 & \\
\hline Andere baan buiten de politie & + & \\
\hline Vergelijkbare baan vinden & - & \\
\hline Dezelfde rang & 0 & \\
\hline Baan met specialisme & + & \\
\hline Baan met leidinggeven & 0 & \\
\hline Rang hoger & 0 & \\
\hline \multicolumn{3}{|l|}{ Loopbaanwensen (over 5 jaar) } \\
\hline Werkzaam in huidig domein & & 0 \\
\hline Werkzaam in ander domein & & 0 \\
\hline Werkzaam als specialist & & 0 \\
\hline Werkzaam als leidinggevende & & 0 \\
\hline Rang hoger & & 0 \\
\hline
\end{tabular}

Bron: ROA enquête onder politiemensen

Bovendien blijkt uit de tabel dat de loopbaanwensen geen rol spelen in de beslissing om de komende vijf jaar een vervolgopleiding te volgen. Of iemand nu wil blijven werken in zijn/haar huidige domein, of juist naar een ander domein wil wisselen, zich wil specialiseren of juist wil richten op leidinggeven, de kans dat iemand de komende vijf jaar een vervolgopleiding denkt te gaan volgen is hieraan niet gerelateerd. In Hoofdstuk 3 zagen we dat de meest gevolgde vervolgopleidingen de specialistische opleidingen zijn, en dat dit tevens de opleidingen zijn die het vaakst worden afgewezen. Ook zagen we dat veel medewerkers aangeven dat toezeggingen met betrekking tot loopbaanontwikkeling niet altijd worden nagekomen. Met andere woorden: wensen gaan niet altijd in vervulling. Het is daarom wellicht niet verrassend dat de wens om over vijf jaar een baan met specialisme te hebben geen invloed heeft op de

37. De persoonlijkheidskenmerken zijn niet opgenomen in de tabel omdat er slechts één persoonlijkheidskenmerk significant gerelateerd blijkt te zijn aan de verwachte vervolgopleiding (nadat er gecontroleerd wordt voor persoon- en werk-gerelateerde factoren en loopbaankansen): In Kolom (2) blijkt de mate van positieve reciprociteit negatief samen te hangen met de verwachting om de komende vijf jaar een vervolgopleiding te gaan volgen. 
verwachte vervolgopleidingsdeelname, maar dat de kans over vijf jaar een dergelijke baan te hebben wel van invloed is.

Hetzelfde geldt voor mensen die binnen vijf jaar graag een hogere rang zouden willen hebben: dit is niet van invloed op de kans dat zij binnen vijf jaar aan een vervolgopleiding zullen deelnemen. Het verwachte leergedrag van politiemensen is dus niet afhankelijk van hun loopbaanwensen, maar wordt wel beïnvloed door hun verwachte loopbaankansen. Dit suggereert een efficiënte manier van het bijblijven in het politievak en het verdiepen of verbreden van de kennis of vaardigheden.

\subsection{Eigen bereidheid aangaande een vervolgopleiding in de toekomst}

Tot nu toe hebben we gezien dat iets minder dan $70 \%$ van de respondenten verwacht de komende vijf jaar een werk-gerelateerde niet-verplichte vervolgopleiding te gaan volgen. Hiermee is echter nog niets gezegd over de bereidheid om zelf het initiatief te nemen, zelf voor de vervolgopleiding te betalen of deze in eigen tijd te gaan volgen. Daarom hebben we aan de respondenten die aangegeven hebben dat zij binnen vijf jaar een vervolgopleiding denken te gaan volgen, gevraagd of zij helemaal, gedeeltelijk of helemaal niet bereid zijn:

- zelf het initiatief te nemen voor de vervolgopleiding

- zelf voor de vervolgopleiding te betalen

- de vervolgopleiding buiten werktijd te volgen

Uit Figuur 4.8 Panel (a), blijkt dat de meeste politiemensen wel degelijk bereid zijn zelf het initiatief te nemen voor het volgen van een vervolgopleiding. $7 \mathrm{I} \%$ van de politiemensen geeft aan helemaal zelf het initiatief te gaan nemen, en nog eens $27 \%$ geeft aan dat zij gedeeltelijk eigen initiatief gaan nemen. Slechts $2 \%$ denkt helemaal geen eigen initiatief te nemen. Dit is lijn met de bevindingen in Figuur 3.I4, waarin te zien is dat al bij de meest recent gevolgde vervolgopleiding $75 \%$ van de politiemensen (gedeeltelijk) zelf het initiatief hiervoor heeft genomen. In aanvullende analyses hebben wij bekeken in hoeverre de mate van eigen initiatief nemen voor een vervolgopleiding gerelateerd is aan de verschillende persoon-, werk- en persoonlijkheidskenmerken. Het blijkt dat persoonskenmerken niet bepalend zijn voor de mate waarin politiemensen initiatief denken te gaan nemen. Er is bovendien maar één werk-gerelateerde factor die er toe doet: het blijkt dat mensen binnen het domein 'intake \& service' minder bereid zijn zelf het initiatief te nemen dan anderen binnen de politie. Persoonlijkheidskenmerken lijken nog het meest gerelateerd te zijn aan het eigen initiatief. De mate waarin iemand het leuk vindt om te leren is het significant positief gerelateerd aan de bereidheid tot het nemen van eigen initiatief. Maar ook iemands risicovoorkeur, de mate van verantwoordelijkheidsgevoel voor eigen kennis en vaardigheden en de mate van het stellen van doelen, blijken (zwak) positief significant gecorreleerd te zijn aan de bereidheid tot het nemen van initiatief. 


\section{Figuur 4.8}

Eigen bereidheid met betrekking tot vervolgopleidingen de komende vijf jaar

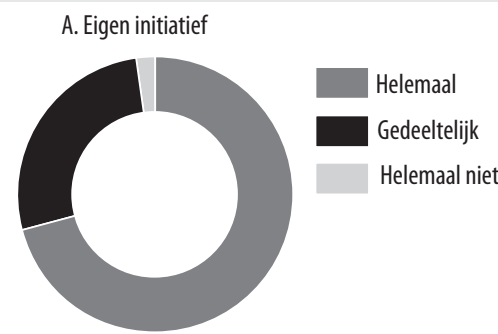

\section{B. Zelf betalen}

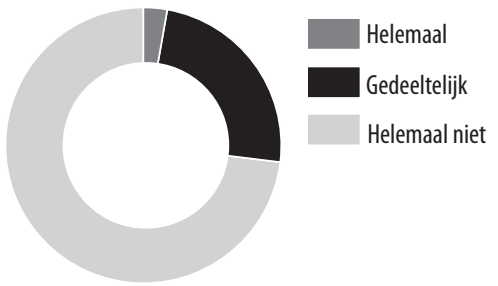

\section{In eigen tijd}

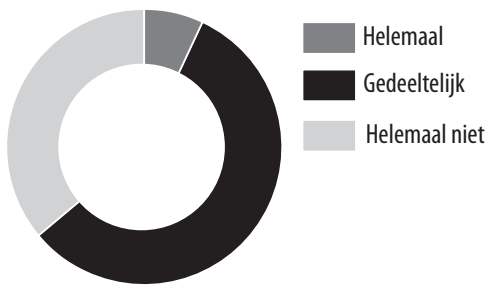

Bron: ROA enquête onder politiemensen

De grote bereidheid met betrekking tot het eigen initiatief staat in contrast met de uiterst geringe bereidheid om zelf voor een vervolgopleiding te gaan betalen. Slechts $3 \%$ geeft aan bereid te zijn de vervolgopleiding helemaal zelf te willen betalen (Panel b). ${ }^{38}$ Bijna $25 \%$ is wel bereid gedeeltelijk zelf voor de vervolgopleiding te betalen. Vergeleken met Figuur 3.I4, waarin werd getoond dat de meest recent gevolgde vervolgopleiding in $94 \%$ van de gevallen door de werkgever werd betaald, is het positief dat al een kwart van de respondenten bereid is in de toekomst gedeeltelijk zelf een bijdrage in de kosten te leveren. Vrouwen blijken een hogere bereid te hebben om zelf te betalen voor hun vervolgopleiding dan mannen. Ook hoofdinspecteurs zijn in meerdere mate bereid om zelf voor hun vervolgopleiding te betalen. Persoonlijkheidskenmerken blijken ook van invloed te zijn. Met name de mate waarin iemand bereid is risico's te nemen en de mate waarin iemand zichzelf doelen stelt voor de toekomstige carrière zijn positief gerelateerd aan de bereidheid om zelf voor de vervolgopleiding te betalen. Onder welke voorwaarden de bereidheid toeneemt om zelf (deels) voor een vervolgopleiding te betalen, zien we in Hoofdstuk 6.

De bereidheid tot het volgen van een vervolgopleiding buiten werktijd is op het eerste gezicht beperkt (Panel c). 36\% van de politiemensen is hier niet toe bereid. Slechts $7 \%$

38. Het gaat hier voornamelijk om politiemensen die een opleiding buiten de PA willen doen (I4 van de I6 politiemensen die aangeven helemaal bereid te zijn zelf voor de vervolgopleiding te willen betalen willen een opleiding buiten de PA gaan doen, de andere twee willen een leidinggevende opleiding gaan doen). 
is volledig bereid om de geplande vervolgopleiding buiten werktijd te gaan volgen. ${ }^{39}$ Bijna zes op de tien politiemensen geeft aan bereid te zijn om de vervolgopleiding gedeeltelijk in eigen tijd te gaan volgen. Echter, vergeleken met Figuur 3.I4 waarin is getoond in wiens tijd de meest recent gevolgde vervolgopleiding werd gevolgd, is dit een positieve ontwikkeling, aangezien de meeste opleidingen in de huidige situatie volledig onder werktijd plaatsvinden. De mate waarin politiemensen bereid zijn de vervolgopleiding in eigen tijd te volgen, blijkt niet afhankelijk van persoonskenmerken. Ook rang en functie, evenals een voorgeschiedenis met een vervolgopleiding blijken niet van invloed op de bereidheid tot opleiden in eigen tijd. Het blijkt echter dat iemand die zeer bereid is risico's te nemen in hogere mate bereid is om in eigen tijd aan een vervolgopleiding deel te nemen. Ook mensen die relatief meer waarde hechten aan de toekomst dan aan het heden, zijn in hogere mate bereid om een vervolgopleiding in eigen tijd te gaan volgen.

Uit nadere analyses blijkt bovendien dat de mensen die aangeven (gedeeltelijk) op eigen initiatief een vervolgopleiding te willen gaan volgen, ook vaker bereid zijn deze opleiding (gedeeltelijk) buiten werktijd te volgen. In mindere mate wordt deze positieve correlatie ook gevonden met de bereidheid tot een eigen financiële bijdrage.

In Figuur 4.9 is te zien in hoeverre politiemensen zelfmelders denken te zijn in de nabije toekomst. Op basis van de verwachte deelname aan vervolgopleidingen de komende vijf jaar en hun bereidheid tot het nemen van initiatief, tot het betalen van de vervolgopleiding en tot het volgen van de opleiding in eigen tijd, is weergegeven hoeveel procent verwacht een volledige, gedeeltelijk of niet- zelfmelder te zijn.

\section{Figuur 4.9}

(gedeeltelijk) Zelfmelden in de komende vijf jaar

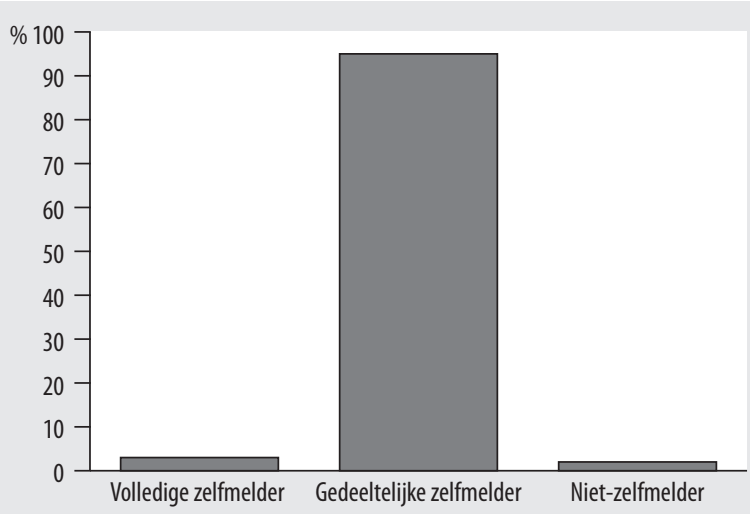

Bron: ROA enquête onder politiemensen

39. Ruim $40 \%$ van de politiemensen die aangeeft de vervolgopleiding volledig in eigen tijd te gaan volgen verwacht een opleiding buiten de PA te gaan volgen. Ook is er een positieve correlatie te vinden tussen de mate waarin iemand bereid is de vervolgopleiding in eigen tijd te volgen en de geschatte kans dat iemand binnen vijf jaar een baan buiten de politie heeft. 
De figuur laat zien dat slechts een klein percentage politiemensen (3\%) van plan is volledig zelfmelder te zijn, dit wil zeggen volledig het initiatief te nemen en te investeren in de training in termen van IOO\% eigen geld en I00\% eigen tijd. Het percentage politiemensen dat bereid is om (gedeeltelijk) het initiatief te nemen voor de vervolgopleiding en/of deze (deels) zelf te betalen en/of gedeeltelijk in eigen tijd te volgen is flink hoger: $95 \%$ geeft aan gedeeltelijk zelfmelder te zijn voor de vervolgopleiding die zij denken te gaan volgen. Dit hoge percentage wordt vooral veroorzaakt doordat veel politiemensen denken (gedeeltelijk) eigen initiatief te gaan nemen (al dan niet met een (gedeeltelijke) investering in tijd). Slechts twee procent is van plan op geen enkele manier zelf bij te dragen. Dit wil zeggen dat zij ervan uitgaan dat de vervolgopleiding die ze de komende vijf jaar denken te gaan volgen zowel op initiatief van de werkgever, als door financiering van de werkgever en in tijd van de werkgever gevolgd gaat worden. 


\section{Prikkels voor het volgen van een vervolgopleiding}

Om in de toekomst meer politiemensen een opleiding te laten volgen als 'zelfmelder', is het eerst noodzakelijk dat politiemensen in algemene zin een positieve intentie tot opleiden hebben. Immers, als men niet verwacht om een opleiding te volgen, kan men ook geen zelfmelder worden. Voordat we ingaan op de prikkels die het zelfmelden beïnvloeden hebben we daarom eerst gekeken naar de prikkels die de opleidingsbereidheid in het algemeen beïvloeden.

Ruim 30\% van de politiemensen verwacht niet dat ze binnen vijf jaar een vervolgopleiding zullen volgen. Deze groep geeft aan dat hun bereidheid om dit wel te doen vergroot wordt door de volgende prikkels: de vervolgopleiding onder werktijd kunnen volgen, de vervolgopleiding leidt tot een hoger salaris binnen de huidige functie, de vervolgopleiding wordt betaald door de werkgever en een vervolgopleiding naar keuze mogen volgen.

Als we de focus verleggen van deze groep die niet verwacht in de toekomst aan een opleiding deel te nemen en we kijken weer naar de gehele groep respondenten, dan vinden we dat er voor politiemensen in het algemeen ook diverse prikkels zijn die deelname aan een vervolgopleiding kunnen stimuleren. Het betreft met name: de vervolgopleiding onder werktijd kunnen volgen, de opleiding tijd- en plaats onafhankelijk kunnen volgen en de opleiding modulair kunnen volgen. De prikkels werken beter op politiemensen die in de laatste drie jaar geen opleiding gevolgd hebben, dan op politiemensen die in de laatste drie jaar wel een vervolgopleiding hebben gevolgd. 


\section{$5.1 \quad$ Inleiding}

Uit Hoofdstuk 4 is gebleken dat $30 \%$ van de politiemensen denkt geen vervolgopleiding te gaan volgen in de komende vijf jaar. In de paragrafen 5.2 en 5.3 zoomen we in op deze groep politiemensen en gaan in op de vraag waarom deze politiemensen niet van plan zijn de komende vijf jaar een vervolgopleiding te gaan volgen (paragraaf 5.2). Vervolgens beschrijven we welke maatregelen van invloed kunnen zijn om deze mensen toch bereid te krijgen om de komende vijf jaar een vervolgopleiding te gaan volgen (paragraaf 5.3).

In paragraaf 5.4 zoomen we weer uit en bestuderen we weer de gehele groep politiemensen die aan het onderzoek heeft meegewerkt. We kijken voor de gehele groep welke prikkels en condities de kans verhogen of verkleinen dat ze in de toekomst (nog) een vervolgopleiding gaan volgen. Deze prikkels zijn relevant omdat de bereidheid tot deelname aan een vervolgopleiding an sich, aanwezig moet zijn als voorwaarde om überhaupt over zelfmelden na te denken. Wie immers niet bereid is om aan een vervolgopleiding deel te nemen, zal ook geen afweging hoeven maken over eigen initiatief of eigen investering in tijd of geld.

\subsection{Waarom is een deel van de politiemensen niet van plan een vervolgopleiding te gaan volgen?}

In de enquête hebben we de medewerkers die aangegeven hebben dat zij binnen vijf jaar géén vervolgopleiding denken te gaan volgen gevraagd wat hiervoor de belangrijkste reden is. ${ }^{{ }^{\circ}}$ In Figuur 5.I is een overzicht van de antwoorden weergegeven. De meest genoemde reden is dat men binnenkort met pensioen gaat. $32 \%$ van de politiemensen die de komende vijf jaar geen vervolgopleiding denkt te volgen, verwacht binnen afzienbare tijd met pensioen te gaan. Het is dan ook niet zo verrassend dat deze groep niet van plan is binnen vijf jaar nog een niet-verplichte werk-gerelateerde opleiding te volgen. Als ze al een opleiding zouden afronden in de korte tijd die nog tot aan pensionering rest, dan zijn er nauwelijks werkzame jaren over om nuttig van de nieuwe kennis en vaardigheden gebruik te maken. Dit is anders voor de twee andere redenen die relatief vaak genoemd zijn:

- Mijn leidinggevende staat het niet toe (I4\%)

- Mijn huidige baan bevalt mij goed (I2\%).

40. Uit Hoofdstuk 2 is al gebleken dat het hier met name oudere politiemensen betreft. Ook politiemensen die de afgelopen drie jaar nog geen vervolgopleiding hebben gevolgd hebben een grotere kans om ook aan te geven voor de komende vijf jaar geen vervolgopleiding te verwachten te volgen. Dit bleek echter niet te verklaren door middel van persoonlijkheidskenmerken zoals tijdsvoorkeur en reciprociteit. Ook geslacht bleek geen rol te spelen voor de verwachte deelname aan vervolgopleidingen de komende vijf jaar. 
Figuur 5.1

Belangrijkste reden voor het niet denken aan een vervolgopleiding deel te nemen binnen vijf jaar

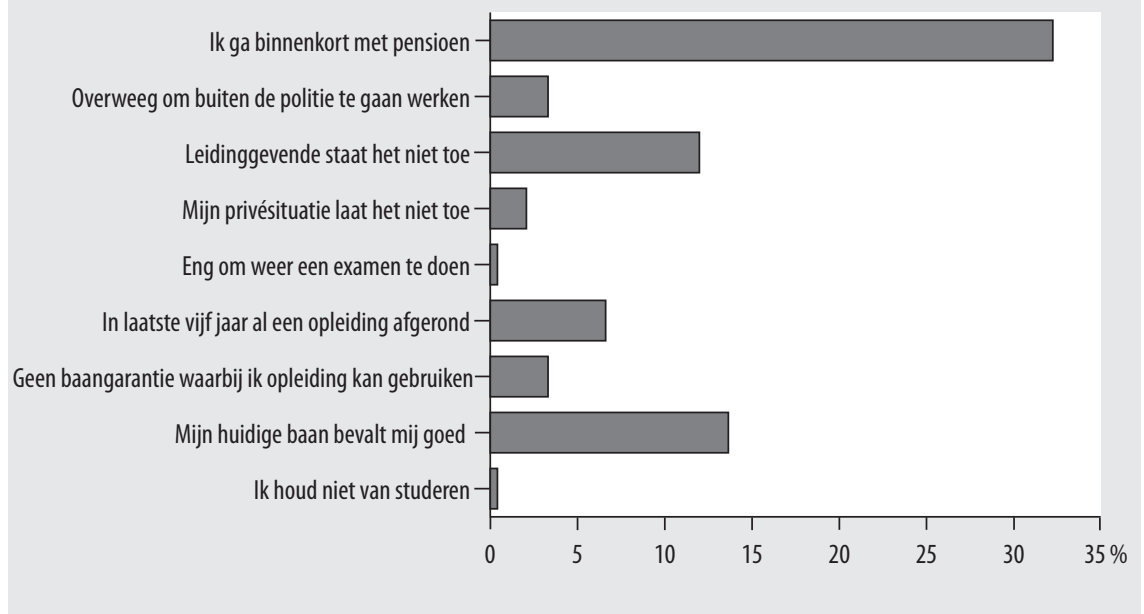

Bron: ROA enquête onder politiemensen

De observatie dat I4\% denkt geen vervolgopleiding te gaan volgen omdat hun leidinggevende het niet toestaat, is in lijn met de bevindingen in Hoofdstuk 2. Daar zagen we dat politiemensen die de afgelopen drie jaar geen vervolgopleiding hebben gevolgd ook vaak als belangrijkste reden aangeven dat hun leidinggevende het niet toe stond. Bovendien zagen we dat leidinggevenden regelmatig aanvragen voor vervolgopleidingen van medewerkers afwijzen.

Onder de groep politiemensen die verwachten dat hun leidinggevende een opleiding niet zal toestaan, lijkt dus wél een vorm van positieve intentie te bestaan om een vervolgopleiding te volgen. De aanpak hoeft dan echter niet noodzakelijkerwijs alleen gericht te zijn op de politiemensen zelf, maar misschien alleen op de leidinggevenden of op beide. Op wie men zich moet richten hangt af van de redenen voor leidinggevenden om deelname aan vervolgopleidingen af te wijzen. Het kan zijn dat er een betere afstemming nodig is tussen politiemensen en de leidinggevenden in het type vervolgopleiding dat nut heeft voor zowel de politiemedewerker zelf en voor het team waarin hij/zij werkzaam is. Bovendien kan het ook zo zijn dat leidinggevenden zich meer open moeten gaan stellen voor het doorleren van medewerkers in hun teams. Dit vraagt misschien een cultuuromslag onder de leidinggevenden binnen de politie. Maar het kan ook zo zijn dat er van politiemensen meer eigen bereidheid tot betalen en doorleren in eigen tijd gewenst is. Indien politiemensen in eigen tijd en met eigen financiële middelen een vervolgopleiding zouden volgen is het maar de vraag of toestemming van de leidinggevende nog nodig is. 


\subsection{Hoe kunnen politiemensen die niet van plan zijn een vervolgopleiding te gaan volgen gestimuleerd worden dit wel te doen?}

Het blijkt dat ongeveer $30 \%$ van de politiemensen - onder de huidige omstandigheden - niet denkt de komende vijf jaar een vervolgopleiding te gaan volgen. Om deze groep in de toekomst te laten nadenken over het volgen van een opleiding als (gedeeltelijk) zelfmelder, zullen ze dus eerst tot opleiden an sich geprikkeld moeten worden. Daarom hebben we hen gevraagd om aan te geven of onder bepaalde omstandigheden de kans dat zij wel aan een vervolgopleiding zullen deelnemen, toeneemt, gelijk blijft of zal afnemen. ${ }^{4 \mathrm{I}}$ Figuur 5.2 toont de resultaten.

Figuur 5.2

Prikkels voor politiemensen die niet van plan zijn een vervolgopleiding te gaan volgen

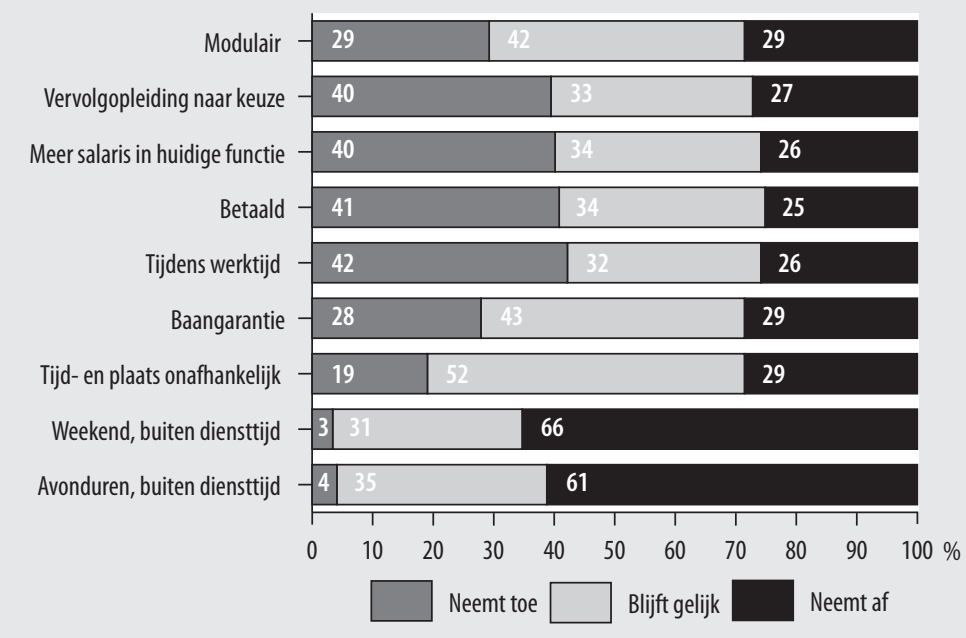

Bron: ROA enquête onder politiemensen

Allereerst valt op dat de mogelijkheid om een vervolgopleiding te volgen in het weekend of in de avonduren (buiten diensttijd) de kans alleen maar verkleint dat deze groep politiemensen binnen vijf jaar wel een vervolgopleiding denkt te gaan volgen. $65 \%$ en $60 \%$ van de respondenten geeft hier namelijk aan dat het kunnen volgen van een vervolgopleiding in respectievelijk het weekend of de avonduren de kans verkleint. Er is echter ook een aantal omstandigheden, waarbij deze groep politiemensen de kans zien toenemen dat ze aan een vervolgopleiding gaan deelnemen:

- Als ze vervolgopleidingen tijdens werktijd kunnen volgen (42\%)

- Als de werkgever betaalt voor de vervolgopleiding (4I\%)

- Als het volgen van een vervolgopleiding leidt tot een hoger salaris in huidige functie $(40 \%)$

- Als ze een vervolgopleiding naar keuze kunnen volgen (39\%).

4I. Deze vraag is niet gesteld aan politiemensen die aangegeven hebben geen vervolgopleiding te gaan volgen de komende vijf jaar omdat zij binnen afzienbare tijd met pensioen denken te gaan. 
Op basis hiervan kan geconcludeerd worden dat er toch diverse mogelijkheden zijn om de opleidingsbereidheid van deze groep politiemensen, die aangaven niet van plan te zijn in de komende jaren een opleiding te volgen, te beïnvloeden.

\subsection{Prikkels voor het volgen van een vervolgopleiding}

In de voorgaande paragrafen keken we naar de groep politiemensen die niet verwachten dat ze in de komende vijf jaar aan een vervolgopleiding gaan deelnemen. In deze paragraaf zoomen we weer uit en kijken we weer naar alle respondenten die aan het onderzoek hebben meegewerkt. Zoals gerapporteerd in Hoofdstuk 3, is aan alle respondenten gevraagd of zij de afgelopen drie jaar een (vervolg) opleiding gevolgd hebben. Vervolgens hebben we de respondenten een aantal mogelijke vormen van flexibel onderwijs voorgelegd en gevraagd of onder deze onderwijsvormen de kans verandert dat zij in de toekomst (nog) een vervolgopleiding zullen volgen. In Figuur 5.3 is een overzicht weergegeven van hun antwoorden. We hebben een onderscheid gemakt tussen politiemensen die de afgelopen drie jaar wel of geen vervolgopleiding gevolgd hebben.

\section{Figuur 5.3}

Vormen van flexibel onderwijs en de mate waarin ze opleidingsbereidheid verhogen

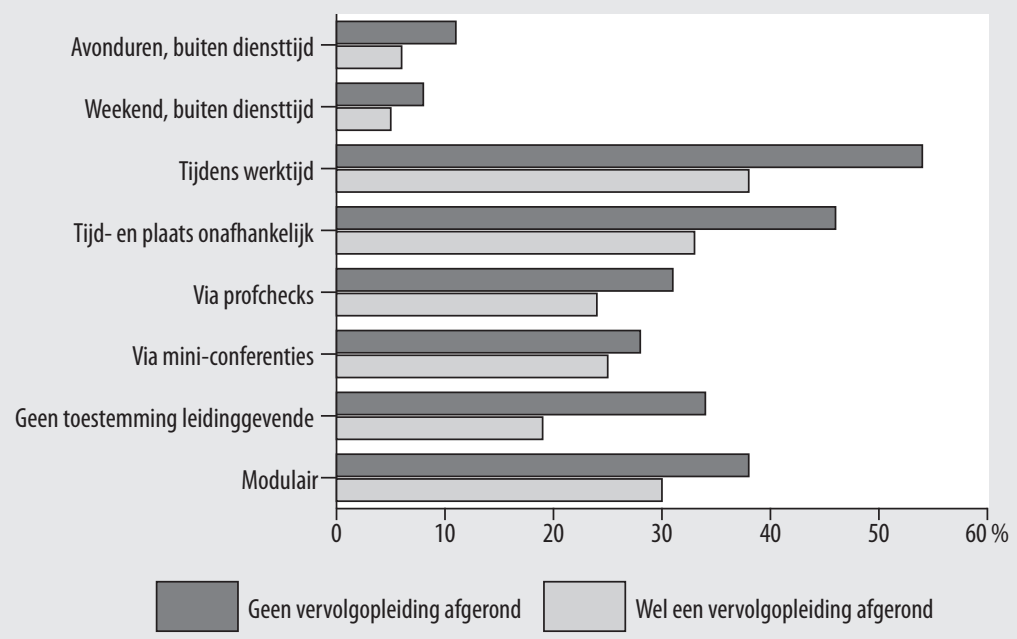

Bron: ROA enquête onder politiemensen

De figuur laat zien dat politiemensen die nog geen vervolgopleiding gevolgd hebben makkelijker te stimuleren zijn om dit alsnog te doen, dan politiemensen die al wel een vervolgopleiding gevolgd hebben in de afgelopen drie jaar. Met name de mogelijkheid om tijdens werktijd aan een vervolgopleiding te kunnen deelnemen, verhoogt de kans dat iemand in de toekomst een vervolgopleiding gaat doen. Dit geldt voor politie- 
mensen die nog geen vervolgopleiding afgerond hebben in meerdere mate $(54 \%)$ dan voor politiemensen die al wel een vervolgopleiding afgerond hebben $(38 \%)$. De mogelijkheid tot tijd- en plaats onafhankelijk leren en het modulair volgen van onderwijs verhogen ook de kans dat politiemensen in de toekomst een vervolgopleiding gaan volgen. Een gebruikelijke vorm van tijd- en plaats onafhankelijk leren die binnen de zorgsector veel gebruikt wordt is E-learning. Een grote zorginstelling uit de Randstad biedt medewerkers de mogelijkheid om E-learning modules van thuis uit te volgen, maar compenseert wel volgens een afgesproken vergoeding de besteedde tijd. Op deze manier kunnen kennis-componenten van een vervolgopleiding makkelijk vanuit huis worden gevolgd. Daardoor hoeft de medewerker voor die componenten niet vrij geroosterd te worden zodat er minder bezettingsproblemen zijn. Binnen deze zorginstelling blijken medewerkers deze vorm van doorleren ook nog eens leuk te vinden.

Voor bijna 35\% van de politiemensen die de afgelopen drie jaar nog geen vervolgopleiding heeft gevolgd, geldt dat het volgen van een vervolgopleiding zonder toestemming nodig te hebben van hun leidinggevende hen stimuleert om in de toekomst aan een vervolgopleiding deel te nemen. Het aanbieden van onderwijs in de avonduren en in het weekend (buiten diensttijd) stimuleert vrijwel niemand.

In aanvullende analyses hebben we, voor iedere vorm van flexibel onderwijs die in Figuur 5.3 is opgenomen, onderzocht of persoonskenmerken, werk-gerelateerde en persoonlijkheidskenmerken van invloed zijn op de mate waarin politiemensen met deze onderwijsvormen te stimuleren zijn om (nog) een vervolgopleiding te gaan volgen..$^{22}$ Echter, persoonskenmerken en werk-gerelateerde kenmerken blijken hierop niet van invloed te zijn.

Wat wél van invloed is, is het recente opleidingsverleden. Voor vrijwel alle vormen van flexibel onderwijs geldt dat de kans op het volgen van (nog) een vervolgopleiding significant lager is voor politiemensen die de afgelopen drie jaar al een vervolgopleiding gevolgd hebben. ${ }^{43}$ Dit bleek ook al uit de Figuren 5.2 en 5.3 .

Persoonlijkheidskenmerken blijken ook van belang te zijn als het gaat om de mate waarin politiemensen van plan zijn om (nog) een vervolgopleiding te gaan volgen. Indien men het leuk vindt om nieuwe dingen te leren, neemt de kans dat men (nog) een vervolgopleiding wil volgen toe als de vervolgopleiding buiten werktijd (in de avonduren of in het weekend) of modulair aangeboden wordt. Voor politiemensen die relatief meer waarde hechten aan de toekomst dan aan het heden geldt dat de kans toeneemt dat zij een vervolgopleiding gaan volgen als de cursus in de avonduren of in het weekend aangeboden wordt. De mate waarin iemand risicoavers is, blijkt gerelateerd te zijn aan de kans dat iemand een vervolgopleiding van plan is te volgen

42. Er is gebruik gemaakt van ordered probit modellen.

43. De enige uitzondering is gevonden voor het modulair volgen van een vervolgopleiding. Of men in de afgelopen drie jaar al een vervolgopleiding heeft gevolgd of niet, beide zijn evenveel te stimuleren om (nog) een vervolgopleiding te volgen door het aanbieden van modulair onderwijs. 
indien deze tijdens werktijd, modulair of via miniconferenties wordt aangeboden. Hoe meer men bereid is risico's te nemen, hoe moeilijker het is om politiemensen te stimuleren een vervolgopleiding te laten volgen tijdens werktijd, modulair of via miniconferenties. Het modulair aanbieden van een vervolgopleiding blijkt de bereidheid om een vervolgopleiding te volgen te verhogen voor politiemensen die positief wederkerig zijn. 



\section{Prikkels ter vergroting van het aantal zelfmelders}

Het blijkt dat prikkels die politiemensen stimuleren om aan een vervolgopleiding deel te nemen, ook de bereidheid tot zelfmelden verhogen. Zelfmelden wil zeggen dat politiemensen bereid zijn een vervolgopleiding te gaan volgen op (gedeeltelijk) eigen initiatief en/ of door middel van (deels) eigen financiering enlof (gedeeltelijk) in eigen tijd. De bereidheid tot het nemen van eigen initiatief blijkt relatief gezien het makkelijkst te beïnvloeden. Prikkels die dit voor meer dan 50\% van de respondenten verhogen zijn: meer salaris in de huidige functie, een door de werkgever betaalde opleiding, opleiden onder werktijd, de mogelijkheid een vervolgopleiding naar keuze te volgen en de garantie op een bij de opleiding passende baan. De bereidheid om een opleiding te volgen in eigen tijd en door middel van eigen financiering wordt voor ongeveer 40-50\% van de respondenten positief beïnvloed door condities zoals het garanderen van een bij de opleiding passende baan, een hoger salaris in de huidige functie en keuze in het type vervolgopleiding. Daarnaast verhoogt het aanbieden van flexibele opleidingsvormen zoals modulair onderwijs en tijden plaats-onafhankelijk onderwijs, de bereidheid tot zelfmelden voor ongeveer 20-35\% van de respondenten. 


\subsection{Inleiding}

Zelfmelders zijn politiemensen die bereid zijn (gedeeltelijk) ofwel op eigen initiatief, ofwel door middel van eigen financiering, ofwel in eigen tijd, een vervolgopleiding te gaan volgen. De enquête biedt twee mogelijkheden om na te gaan wat de prikkels zijn die in de toekomst tot zelfmelden zouden kunnen leiden.

I. Politiemensen is een hypothetische situatie geschetst en hen is gevraagd of zij onder bepaalde voorwaarden aan een vervolgopleiding zouden gaan deelnemen. De voorwaarden in dit gedachten-experiment zijn gericht op eigen betaling en doorleren in eigen tijd. Vervolgens wordt gevraagd of politiemensen op eigen initiatief daadwerkelijk een vervolgopleiding zouden gaan volgen.

2. Politiemensen die aangegeven hebben dat zij de komende vijf jaar een vervolgopleiding denken te gaan volgen, is gevraagd of hun bereidheid tot het nemen van eigen initiatief, het zelf betalen van de vervolgopleiding en het volgen van een vervolgopleiding in eigen tijd zou toenemen, gelijk zou blijven of afnemen als de opleiding in bepaalde vormen van flexibel onderwijs wordt aangeboden. In paragraaf 6.2 en 6.3 gaan we achtereenvolgens in op de bevindingen van deze twee methoden om prikkels van potentiële zelfmelders in kaart te brengen.

\subsection{Een hypothetische situatie...}

Uit Hoofdstuk 5 is gebleken dat met name het moment waarop de vervolgopleiding gevolgd kan worden (in eigen tijd of tijdens werktijd) bepalend is voor de keuze om een vervolgopleiding te volgen. Door respondenten hypothetische situaties voor te leggen, wordt bekeken in hoeverre de bereidheid tot het volgen van een vervolgopleiding afhangt van de mate waarin de vervolgopleiding in eigen tijd en door middel van eigen financiering zou moeten plaatsvinden. ${ }^{44}$ Alle niet-leidinggevende politiemensen (ongeacht hun voorgaande of verwachte deelname aan vervolgopleidingen) kregen allereerst de volgende situatie beschreven:

\section{Tekstbox 6.1}

Stel u ontvangt van uw werkgever een tegoedbon ter waarde van $€ 1.000$,- die u binnen een jaar zou kunnen gebruiken om een opleiding te gaan volgen. $U$ moet deze opleiding volgen en voorbereiden in uw eigen tijd.

Vervolgens werd hen gevraagd hoe groot zij de kans schatten dat ze gebruik zouden maken van deze tegoedbon. In Figuur 6.I ziet u de reactie van de politiemensen.

44. Dit gedachtenexperiment is ook uitgevoerd in de ROA Leven-Lang-Leren Enquête in 2010 en is gebaseerd op gedragseconomische theorieën. Bij Philips Nederland is een vergelijkbare tegoedbon daadwerkelijk ingevoerd en wetenschappelijk onderzocht. Gebruik van de tegoedbon had positieve effecten op trainingsbereidheid en employability-bewustzijn (zie Gerards, R. (20I2), Unemployment and employability: how firms can help. Universitaire Pers Maastricht, Maastricht, ISBN 978-94-6I59I46-3. Of zie: Gerards, De Grip and Witlox (2012). "Employability-miles" and worker employability awareness. ROA-RM 20I2/IO, Maastricht). 
Figuur 6.1

Kans gebruik maken van hypothetische tegoedbon (€1.00o,- maar in eigen tijd)

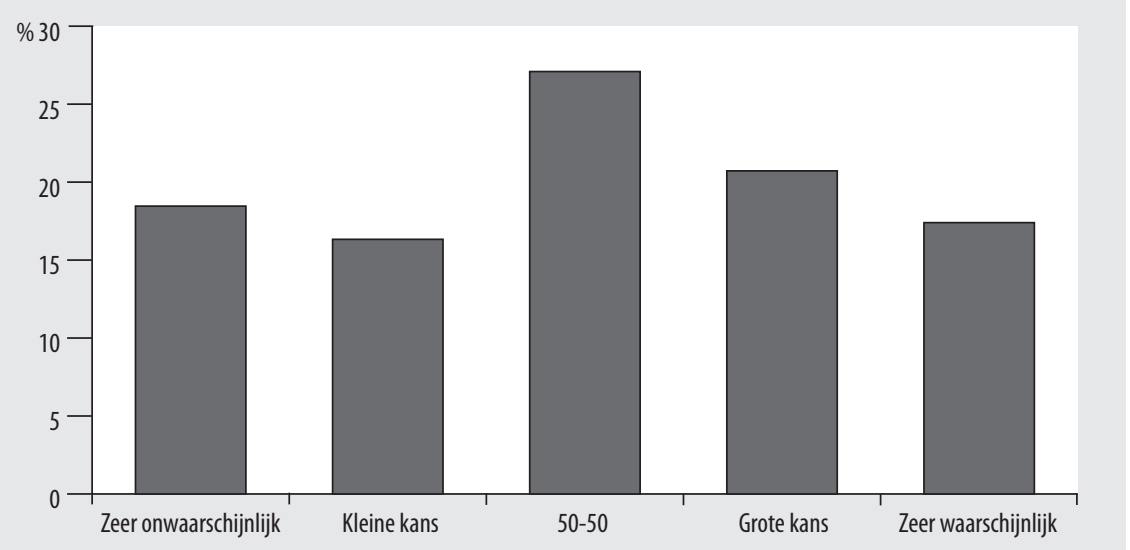

Bron: ROA enquête onder politiemensen

De meningen blijken erg verdeeld te zijn. De meeste politiemensen (27\%) geven aan dat de kans niet waarschijnlijk is, maar ook niet onwaarschijnlijk (50-50). Ongeveer $38 \%$ schat de kans (zeer) groot dat zij van deze tegoedbon gebruik zouden maken. Nog eens 35\% schat de kans (zeer) groot dat zij geen gebruik zouden maken van deze tegoedbon. ${ }^{45}$ Uit nadere analyses blijkt dat het hierbij niet uitmaakt of men de afgelopen drie jaar al een vervolgopleiding gevolgd heeft of niet. Iemands rang blijkt wel van belang. Dit is terug te zien in Figuur 6.2.

Uit de figuur blijkt dat aspiranten het meest aangeven de kans zeer groot te achten dat zij van deze tegoedbon gebruik zouden maken. Bijna $40 \%$ van de aspiranten geeft dit aan, in vergelijking tot I4 tot $20 \%$ van de politiemensen met andere rangen. Met name hoofdinspecteurs en brigadiers achten de kans zeer klein dat zij van de tegoedbon gebruik zouden maken ( 25 en $24 \%$ respectievelijk). Voor veel agenten en hoofdagenten is het om het even.

Aanvullende analyses laten zien dat iemands leeftijd, de mate waarin iemand bereid is risico's te nemen, de mate waarin iemand de toekomst prefereert boven het nu en de mate waarin iemand het leuk vindt om steeds weer nieuwe dingen te leren, de kans verhogen dat iemand gebruik zou willen maken van deze tegoedbon waarin weliswaar in eigen tijd een vervolgopleiding gevolgd moet worden, maar waarvoor de werkgever duizend euro beschikbaar stelt. ${ }^{4}$ Ook het ROA Leven-Lang-Leren onderzoek onder de Nederlandse beroepsbevolking in 2010 laat zien dat persoonlijkheidskenmerken

45. De respondenten van de ROA Leven-Lang-Leren enquête (onder de Nederlandse bevolking) achten de kans gemiddeld groter dat zij gebruik zouden maken van eenzelfde tegoedbon: $13 \%$ acht de kans zeer onwaarschijnlijk, $8 \%$ acht de kans klein, $20 \%$ geeft een $50-50 \%$ kans aan, $27 \%$ acht de kans groot en $33 \%$ acht de kans zeer waarschijnlijk (Borghans et al. 20II).

46. We hebben een ordered probit analyse uitgevoerd waarin alle eerder vernoemde persoon-, werk- en persoonlijkheidskenmerken zijn opgenomen. Rang blijkt niet langer een rol te spelen nadat gecontroleerd wordt voor andere factoren. 
zoals risicovoorkeur een rol spelen in de bereidheid van werkenden om gebruik te maken van een vergelijkbare tegoedbon (Borghans et al. 20II).

Figuur 6.2

Kans gebruik maken van hypothetische tegoedbon, per rang

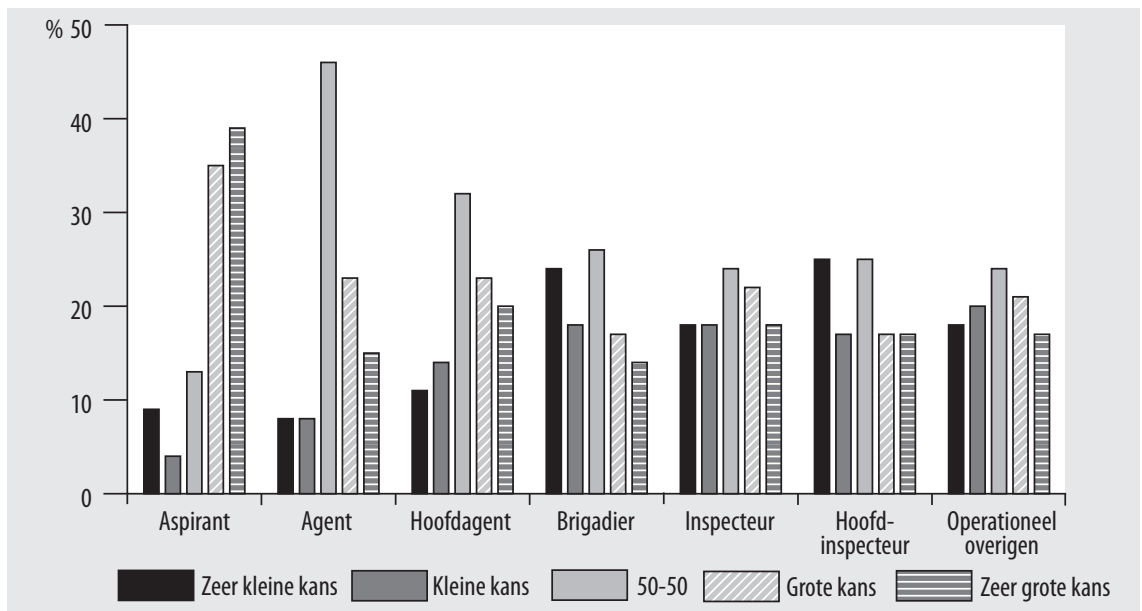

Bron: ROA enquête onder politiemensen

Vervolgens hebben wij de respondenten met de volgende situatie geconfronteerd:

\section{Tekstbox 6.2}

Als u de opleiding inclusief de voorbereiding wel tijdens werktijd zou mogen volgen, hoe groot schat u dan de kans dat u gebruik zou maken van de tegoedbon?

Ten opzichte van de vorige situatie, weerspiegelt deze situatie in grotere mate het huidige beleid bij de politie omtrent in wiens tijd een opleiding doorgaans wordt gevolgd. In Figuur 6.3 zijn de antwoorden weergegeven. Deze figuur ziet er heel anders uit dan Figuur 6.2.

Het volgen van een vervolgopleiding tijdens werktijd en betaald door de werkgever zorgt voor een enorme toename van de kans dat politiemensen gebruik zouden maken van de tegoedbon en dus daadwerkelijk een vervolgopleiding zouden gaan volgen. Slechts II\% acht de kans nog steeds (zeer) klein. Daar tegenover staat dat 30\% de kans groot acht wel in te gaan op dit hypothetische aanbod en $42 \%$ acht de kans zelfs zeer groot. Dit komt waarschijnlijk doordat in een dergelijke situatie zowel de directe kosten (de tegoedbon) als de indirecte kosten (de tijdsinvestering) van de opleiding volledig gedragen worden door de werkgever. Omdat de meeste politiemensen de kans behoorlijk groot schatten dat zij een vervolgopleiding zouden volgen onder deze hypothetische voorwaarden, blijken persoon-, werk- en persoonlijkheidskenmerken 
niet meer zo veel verklarende kracht te hebben. ${ }^{47} \mathrm{Er}$ is echter één uitzondering, politiemensen die het leuk vinden om iets nieuws te leren, achten de kans dat zij gebruik zullen maken van de hypothetische tegoedbon groter (gecontroleerd voor alle andere factoren).

\section{Figuur 6.3}

Kans gebruik maken van hypothetische tegoedbon (€1.000,- en in werktijd)

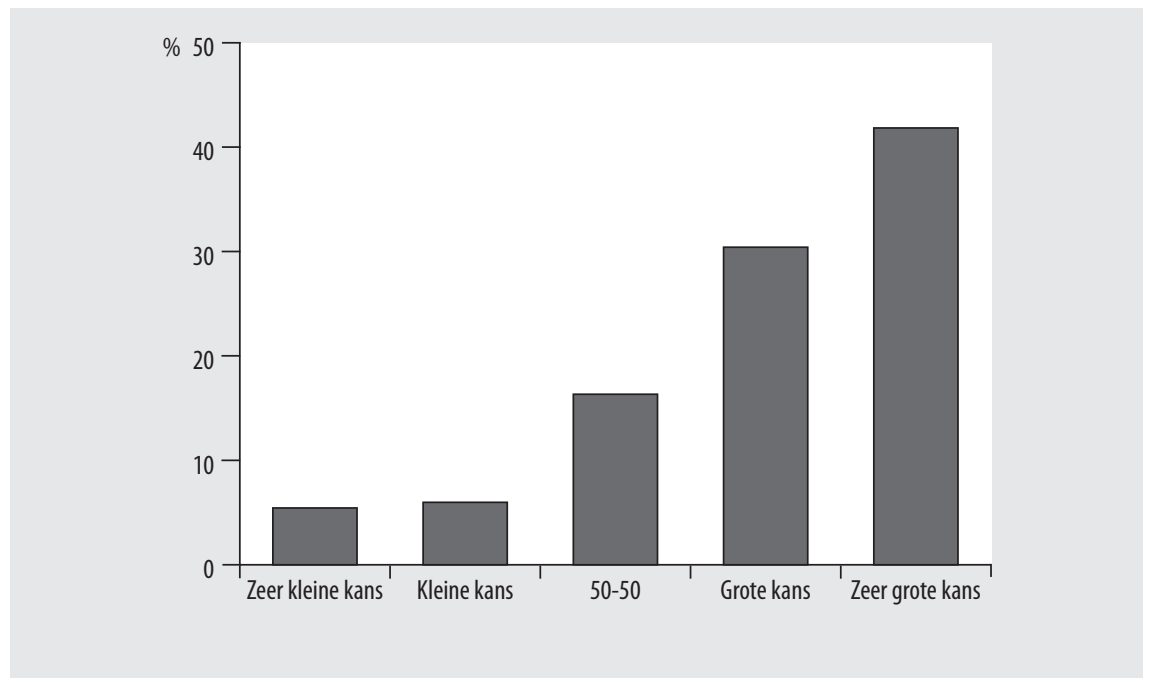

Bron: ROA enquête onder politiemensen

Een laatste situatie die de respondenten werd voorgelegd is stukken minder riant, maar is het meest verregaand wat betreft de eigen bijdrage in tijd en geld (facetten van zelfmelden):

\section{Tekstbox 6.3}

Als u bij de tegoedbon nog een eigen bijdrage van 250 Euro zou moeten betalen, en u de opleiding inclusief voorbereiding in eigen tijd zou moeten doen, hoe groot schat $u$ dan de kans dat u gebruik zou maken van de tegoedbon van $€ 1.000$,-?

In Figuur 6.4 is de reactie van de respondenten te zien. De kans dat politiemensen in dit laatste geval gebruik denken te maken van de tegoedbon is ten opzichte van de vorige situaties het kleinst. Bijna 60\% geeft aan de kans (zeer) klein te achten dat ze in dit geval van de tegoedbon gebruik zouden maken. Nog eens meer dan $20 \%$ geeft aan

47. De respondenten van de ROA Leven-Lang-Leren enquête (onder de Nederlandse bevolking) zijn gemiddeld terughoudender in hun bereidheid tot het gebruik maken van eenzelfde tegoedbon: IO\% acht de kans zeer onwaarschijnlijk, 7\% acht de kans klein, I5\% geeft een 50-50 kans aan, 23\% acht de kans groot en $46 \%$ acht de kans zeer waarschijnlijk. Persoonlijkheidskenmerken zoals openheid, tijd oriëntatie en intrinsieke motivatie blijken binnen deze groep werknemers een rol te spelen in de kans dat zij gebruik maken van de tegoedbon (Borghans et al. 20II). 
dat de kans niet waarschijnlijk is, maar ook niet onwaarschijnlijk..$^{48}$ Toch geeft ook $20 \%$ aan de kans (zeer) groot te achten om onder deze omstandigheden de tegoedbon te gebruiken.

\section{Figuur 6.4}

Kans gebruik maken van hypothetische tegoedbon ( $€$ 1.000,- maar met $€ 250$ eigen bijdrage en in eigen tijd)

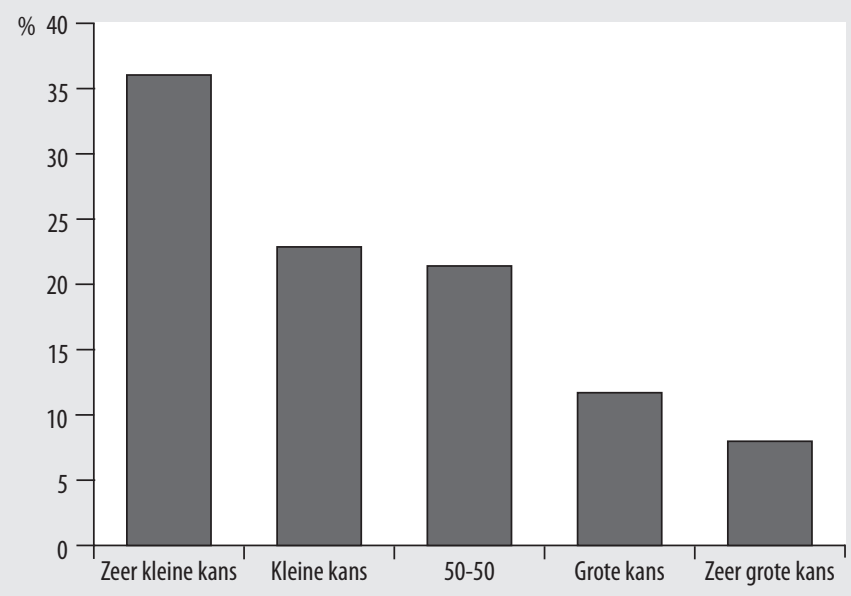

Bron: ROA enquête onder politiemensen

Uit aanvullende analyses blijkt dat vrouwen en relatief oudere politiemensen (gecontroleerd voor werk-gerelateerde kenmerken en persoonlijkheidskenmerken) de kans groter achten dat zij gebruik zouden maken van deze hypothetische tegoedbon waarin een eigen bijdrage noodzakelijk is en waarin het volgen van de vervolgopleiding in eigen tijd dient te gebeuren. Ook politiemensen die bereid zijn meer risico's te nemen, die de toekomst relatief belangrijker vinden dan het heden en die het leuk vinden om nieuwe dingen te leren, hebben een grotere kans dat zij gebruik maken van deze hypothetische tegoedbon. Politiemensen die negatief wederkerig zijn, blijken juist een kleinere kans te hebben om van de tegoedbon gebruik te maken dan zij die niet negatief wederkerig zijn.

De manier waarop politiemensen reageren op de verschillende hypothetische situaties die hen voorgelegd werden, bevestigt het beeld dat ook al bleek uit paragraaf 4.5: in eigen tijd en op basis van eigen financiële middelen is de bereidheid tot het volgen van een vervolgopleiding relatief het kleinst.

48. De respondenten van de ROA Leven-Lang-Leren enquête (onder de Nederlandse bevolking) zijn gemiddeld iets meer bereid om gebruik te maken van eenzelfde tegoedbon: $30 \%$ acht de kans zeer onwaarschijnlijk, $23 \%$ acht de kans klein, $24 \%$ geeft een 50-50\% kans aan, I6\% acht de kans groot en $7 \%$ acht de kans zeer waarschijnlijk (Borghans et al. 20II). 


\subsection{Prikkels voor het verhogen van de eigen bereidheid bij het volgen van een vervolgopleiding}

In Hoofdstuk 4 hebben we gezien dat bijna $70 \%$ van de politiemensen van plan is om de komende vijf jaar een vervolgopleiding te gaan volgen. Aangezien zij al van plan zijn een vervolgopleiding te volgen, zijn ze misschien met de juiste prikkels ook bereid om deze opleiding als volledig of gedeeltelijk zelfmelder te volgen. Dit zijn dus allemaal potentiële zelfmelders. In Figuur 4.8 zagen we in hoeverre deze potentiële zelfmelders bereid zijn om zelf het initiatief te nemen, zelf voor de vervolgopleiding te betalen en de vervolgopleiding in eigen tijd te volgen. Veel politiemensen bleken bereid zelf het initiatief te nemen. Echter, de bereidheid tot eigen betaling en doorleren in eigen tijd is een stuk beperkter. Politiemensen die aangaven gedeeltelijk of helemaal geen eigen bereidheid voor een eigen investering (initiatief, tijd of geld) te hebben, werd vervolgens gevraagd hoe hun bereidheid hiertoe zou veranderen als de vervolgopleiding in bepaalde flexibele onderwijsvormen werd aangeboden of er bepaalde condities aan gekoppeld werden. In Figuur 6.5 is opgenomen hoe iemands bereidheid om eigen initiatief te nemen kan veranderen. ${ }^{49}$

\section{Figuur 6.5}

Verandering bereidheid tot nemen van eigen initiatief

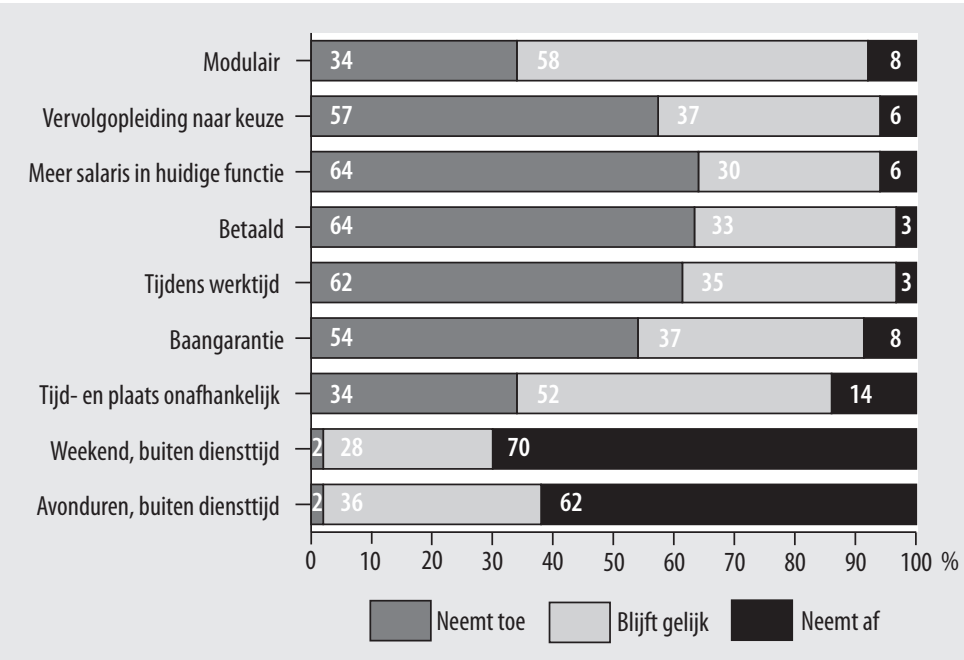

Bron: ROA enquête onder politiemensen

Uit de figuur blijkt dat er behoorlijk wat condities en flexibele onderwijsvormen zijn die de bereidheid tot het nemen van eigen initiatief kunnen verhogen. Vijf hiervan

49. Het betreft alleen politiemensen die aan hebben gegeven dat ze (a) van plan zijn de komende vijf jaar een vervolgopleiding te gaan volgen en (b) momenteel nog niet bereid zijn geheel op eigen initiatief een vervolgopleiding te volgen. $(\mathrm{N}=150)$ 
zorgen ervoor dat de bereidheid tot eigen initiatief van minimaal 50\% van de politiemensen toeneemt. Het betreft:

- Het krijgen van meer salaris in de huidige functie (64\%)

- De vervolgopleiding wordt betaald (63\%)

- De vervolgopleiding kan tijdens werktijd gevolgd worden (6I\%)

- Men kan een vervolgopleiding naar keuze volgen (57\%)

- Er wordt een baangarantie geboden voor een baan passend bij de vervolgopleiding (54\%).

Bovendien blijkt uit Figuur 6.5 dat het modulair of tijd- en plaats-onafhankelijk kunnen volgen van een opleiding voor ruim een derde van de respondenten de bereidheid tot het nemen van eigen initiatief verhoogt. Het aanbieden van vervolgopleiding buiten diensttijd (ofwel in de avonduren of in het weekend) verkleint voor een meerderheid van de respondenten de kans dat men bereid is eigen initiatief te tonen.

\section{Figuur 6.5}

Verandering bereidheid tot nemen van eigen initiatief

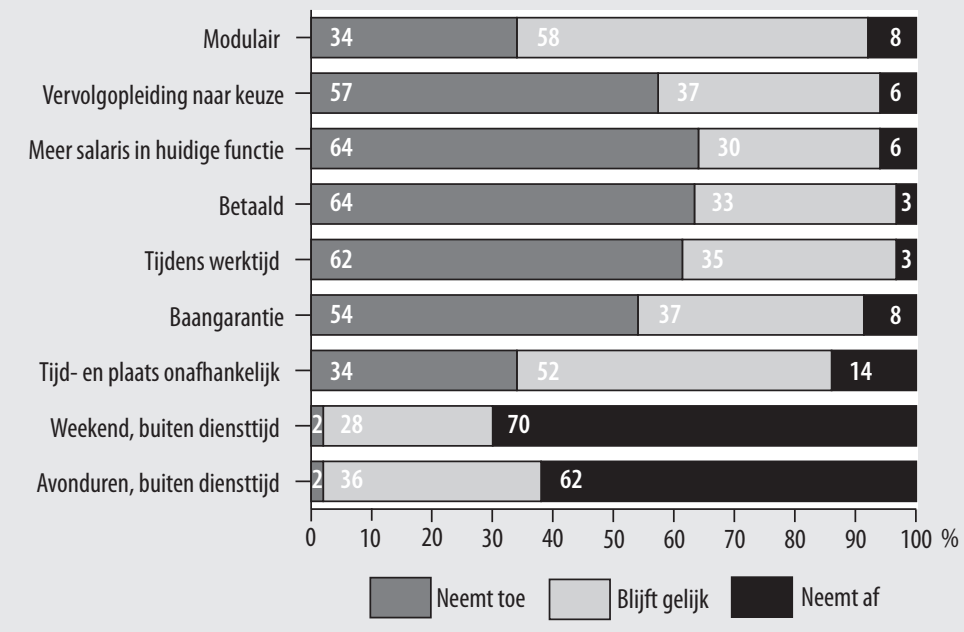

Bron: ROA enquête onder politiemensen

In Figuur 6.6 is weergegeven hoe de bereidheid tot het zelf betalen van een vervolgopleiding veranderd kan worden. ${ }^{5 \circ}$ Uit Hoofdstuk 4 bleek al dat de bereidheid tot het zelf betalen van een vervolgopleiding momenteel erg laag is. Slechts $3 \%$ geeft aan de vervolgopleiding helemaal te willen betalen.

50. Het betreft alleen politiemensen die aan hebben gegeven dat ze (a) van plan zijn de komende vijf jaar een vervolgopleiding te gaan volgen en (b) momenteel nog niet geheel bereid zijn geheel zelf een vervolgopleiding te betalen $(\mathrm{N}=502)$. 


\section{Figuur 6.6}

Verandering bereidheid tot het zelf betalen

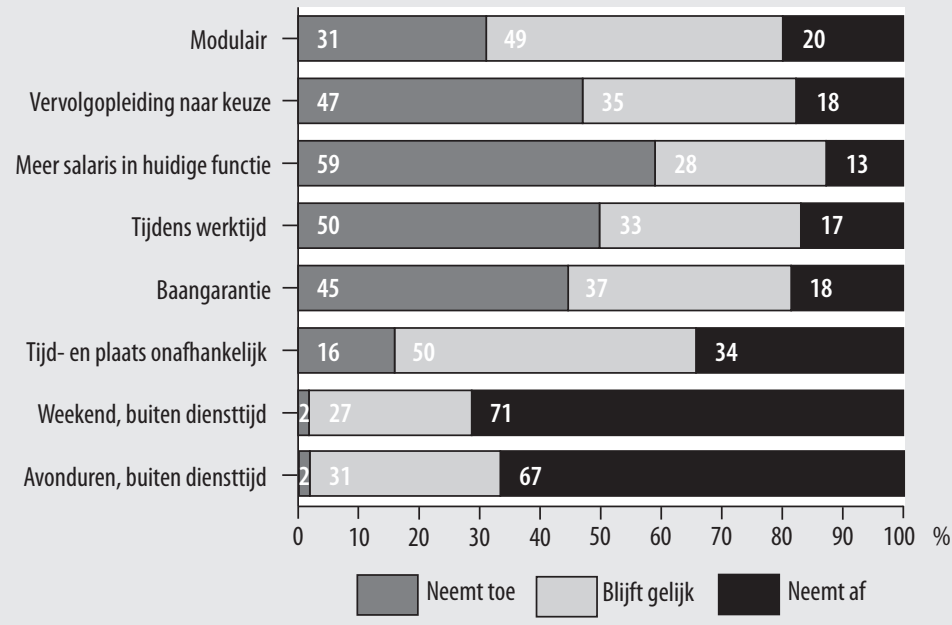

Bron: ROA enquête onder politiemensen

Hoewel er weer een vijftal maatregelen zijn die de bereidheid tot het zelf betalen van een vervolgopleiding kunnen doen stijgen, heeft het op minder politiemensen effect dan toen het ging om de bereidheid tot het nemen van eigen initiatief (zoals te zien was in Figuur 6.5). Slechts één maatregel - het krijgen van meer salaris in de huidige functie - zorgt er voor dat meer dan 50\% van de respondenten aangeeft dat hun bereidheid tot eigen betaling toeneemt. Deze financiële compensatie door salaris kan een manier zijn waarmee de respondenten de vervolgopleiding denken te financieren. Diverse andere maatregelen zijn voor ruim $40 \%$ van de respondenten positief van invloed op de bereidheid tot eigen betaling: het volgen van een opleiding tijdens werktijd, een opleidingen naar keuze volgen en een garantie op een baan passend bij de opleiding. Door modulair onderwijs wordt een kleine 30\% van de respondenten positief beïnvloed. Het aanbieden van vervolgopleidingen in de avonduren en in het weekend werkt tot slot alleen maar averechts.

In Figuur 6.7 is weergegeven hoe de maatregelen de bereidheid tot doorleren in eigen tijd beïnvloeden. ${ }^{51}$ In lijn met de bevindingen in de Figuren 6.5 en 6.6 blijken het aanbieden van modulair en tijd- en plaats-onafhankelijk onderwijs voor $20-30 \%$ van de politiemensen een positieve verandering teweeg te brengen. Het aanbieden van meer salaris in de huidige functie verhoogt de bereidheid tot het doorleren in eigen tijd echter voor de meerderheid van politiemensen (62\%). Als de vervolgopleiding betaald wordt door de politie neemt de bereidheid tot het volgen van een vervolgopleiding in eigen tijd ook voor het merendeel van de politiemensen toe (6r\%). Het

5I. Het betreft alleen politiemensen die aan hebben gegeven dat ze (a) van plan zijn de komende vijf jaar een vervolgopleiding te gaan volgen en (b) momenteel nog niet geheel bereid zijn in eigen tijd een vervolgopleiding te volgen $(\mathrm{N}=474)$. 
aanbieden van vervolgopleidingen in de avonduren en in het weekend zet ook hier geen zoden aan de dijk. Het verkleint vooral de kans dat men bereid is in eigen tijd door te leren.

\section{Figuur 6.7}

Verandering bereidheid doorleren in eigen tijd

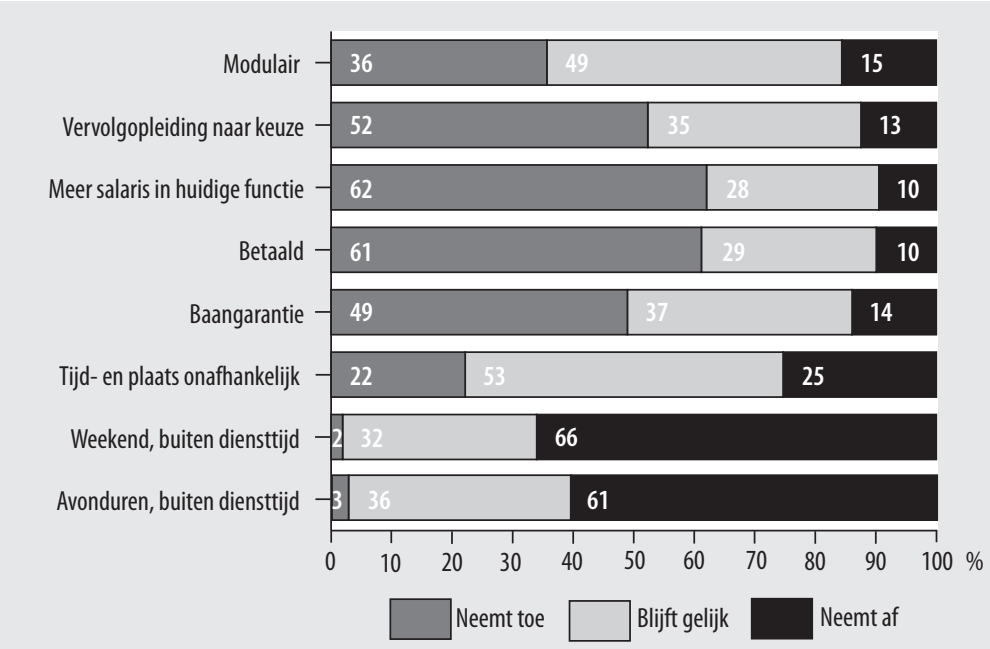

Bron: ROA enquête onder politiemensen 


\section{Belangrijkste bevindingen en slotconclusies}

Vanuit overleg tussen de directeur Politie en de politievakbonden eind 20II is de behoefte kenbaar gemaakt om in de toekomst met betrekking tot het politieonderwijs tot meer 'zelfmelders' te komen. Dat wil zeggen politiemensen die een vervolgopleiding gaan volgen op (deels) eigen initiatief en/of met (gedeeltelijke) inzet van eigen tijd en/of met een eigen financiële bijdrage. Omdat er tot op heden weinig ruimte was voor zelfmelders, is niet bekend welke factoren politiemensen zouden kunnen bewegen om als zelfmelder aan een vervolgopleiding deel te nemen. Ook is niet bekend hoe flexibilisering van het politieonderwijs, gedefinieerd als het aanbieden van variaties in organisatie en vormgeving van het onderwijs, een rol zou kunnen spelen om tot meer zelfmelders te komen. In dit rapport is verslag gedaan van de uitkomsten van het door het ROA uitgevoerde onderzoek dat bestond uit een enquête onder zowel leidinggevende als niet-leidinggevende politiemensen, kwalitatieve gesprekken, focusgroep gesprekken en literatuurstudie.

In de paragrafen 7.I tot en met 7.5 van dit hoofdstuk gaan we in op de belangrijkste bevindingen van het onderzoek en beantwoorden we de onderzoeksvraag hoe politiemensen gestimuleerd c.q. gefaciliteerd kunnen worden, om in de toekomst meer als zelfmelder - op (deels) eigen initiatief, met (gedeeltelijke) inzet van eigen tijd en/ of geld - een vervolgopleiding te volgen, en of flexibilisering van het politieonderwijs daar een rol in kan spelen. In paragraaf 7.6 komen deze bevindingen samen in slotconclusies.

\subsection{Opleidingsdeelname en (gedeeltelijk) zelfmelden tot nu toe}

Binnen de politie wordt veel aan opleiding gedaan. 80\% van de politiemensen die aan het onderzoek meededen heeft de afgelopen drie jaar een al dan niet verplichte opleiding gevolgd voor het werk. Dit is inclusief initiële opleidingen en verplichte opleidingen zoals (periodieke) hercertificeringen. Als we de initiële opleidingen en verplichte opleidingen buiten beschouwing laten en alleen kijken naar werk-gerelateerde vervolgopleidingen zonder een verplicht karakter, dan blijkt dat ruim twee derde van de respondenten de afgelopen drie jaar één of meerdere niet-verplichte vervolgopleidingen heeft gevolgd. 
Volledige zelfmelders, die deze niet-verplichte vervolgopleiding volledig op eigen initiatief hebben gevolgd en dit volledig in eigen tijd deden en zelf betaald hebben, zijn er daarbij nauwelijks (I\%). Het percentage politiemensen dat als gedeeltelijke zelfmelder aan een vervolgopleiding heeft deel genomen is echter niet gering. $84 \%$ van de respondenten geeft aan de meest recent gevolgde vervolgopleiding geheel of gedeeltelijk op eigen initiatief te hebben gevolgd, al dan niet in combinatie met een (gedeeltelijke) eigen inbreng in termen van tijd en/of geld. Het betrof hierbij voornamelijk respondenten die aangaven zelf (mede) het initiatief te hebben genomen voor de vervolgopleiding of deze deels in eigen tijd te hebben gevolgd. Het (mee) betalen aan een opleiding komt zelden voor. Gedeeltelijke zelfmelders kwamen relatief wat vaker voor onder:

- jongere politiemensen

- hogere rangen

- de domeinen leiding, bedrijfsvoering en onderwijs \& kennis/werving \& selectie

- medewerkers die een hoger verantwoordelijkheidsgevoel hebben voor hun eigen kennis, vaardigheden en ontwikkeling

- medewerkers die het leuk vinden om te leren.

\subsection{Verwachte toekomstige deelname aan vervolgopleidingen en bereidheid tot eigen initiatief, deelname in eigen tijd en eigen financiële bijdrage}

Bijna $70 \%$ van de politiemensen verwacht binnen vijf jaar een vervolgopleiding te gaan volgen. Het betreft met name de relatief jonge politiemensen, politiemensen die de afgelopen drie jaar ook al een vervolgopleiding gevolgd hebben en politiemensen die het leuk vinden om nieuwe dingen te leren. De loopbaanwensen die politiemensen hebben zijn daarbij niet van invloed op de verwachte deelname aan vervolgopleidingen. De loopbaankansen die politiemensen voor zichzelf in het verschiet zien zijn echter wel van invloed op de verwachte deelname aan vervolgopleidingen. Politiemensen die verwachten binnen vijf jaar een baan buiten de politie te hebben of een specialistische functie te gaan vervullen, schatten de kans dat zij de komende vijf jaar een vervolgopleiding gaan volgen gemiddeld hoger in.

Van deze groep politiemensen die verwacht in de komende vijf jaar een vervolgopleiding te gaan volgen, blijken de meesten bereid om zelf het initiatief hiervoor te nemen. Daarentegen zijn de bereidheid tot het (gedeeltelijk) zelf betalen van de opleidingen en de bereidheid de opleiding (deels) buiten werktijd te volgen beperkt tot zeer beperkt. Slechts $3 \%$ van deze groep politiemensen verwacht de komende vijf jaar een vervolgopleiding te gaan volgen en hiervoor volledig het initiatief te nemen, dit volledig in eigen tijd te doen en helemaal zelf te betalen (volledig zelfmelder). Desondanks verwacht $95 \%$ van de politiemensen die in de toekomst een opleiding denkt te gaan volgen, dat ze in meer of mindere mate zelf het initiatief zullen nemen, tijd zullen investeren of financieel een bijdrage eraan zullen leveren. Voor eigen initi- 
atief is de bereidheid relatief het grootst, gevolgd door leren in eigen tijd en zelf mee betalen.

\subsection{Prikkels voor het volgen van een vervolgopleiding}

Om in de toekomst meer politiemensen een opleiding te laten volgen als 'zelfmelder', is het eerst noodzakelijk dat politiemensen an sich een positieve intentie tot het volgen van een opleiding hebben. Immers, als men niet verwacht om een opleiding te volgen, kan men ook geen zelfmelder worden. Voordat we ingaan op de prikkels die het zelfmelden beïnvloeden hebben we daarom eerst gekeken naar de prikkels die de opleidingsbereidheid in het algemeen beïnvloeden. We hebben hierbij onderscheid gemakt tussen politiemensen die op dit moment niet verwachten om in de nabije toekomst aan een opleiding deel te nemen en politiemensen die dit wel verwachten te doen.

Ruim 30\% van de politiemensen verwacht niet dat ze binnen vijf jaar een vervolgopleiding zullen volgen. Het grootste deel van deze groep geeft hiervoor als reden dat zij binnenkort met pensioen gaat $(32 \%)$. Echter, ook het ontbreken van toestemming van de leidinggevende (I4\%) en het feit dat de huidige baan goed bevalt (I2\%) worden regelmatig genoemd als hoofdreden om de komende vijf jaar niet aan een vervolgopleiding deel te nemen. Uit het onderzoek blijkt dat er enkele condities zijn die de bereidheid om een vervolgopleiding te gaan volgen onder deze groep aanzienlijk vergroten. De condities die het meest effect hebben zijn:

- De vervolgopleiding kan onder werktijd gevolgd worden

- De vervolgopleiding leidt tot een hoger salaris binnen de huidige functie

- De vervolgopleiding wordt betaald door de werkgever

- Men mag een vervolgopleiding naar keuze volgen.

Als we de focus verleggen van de groep die niet verwacht in de toekomst aan een opleiding deel te nemen en we kijken weer naar de gehele groep respondenten, dan vinden we dat er voor politiemensen in het algemeen ook diverse prikkels zijn die deelname aan een vervolgopleiding kunnen stimuleren. Het betreft in volgorde van populariteit:

- De vervolgopleiding kan onder werktijd gevolgd worden

- De opleiding kan tijd- en plaats onafhankelijk worden gevolgd

- De opleiding modulair kunnen volgen

- De opleiding zonder toestemming van de leidinggevende kunnen volgen.52

52. Dit geldt met name voor politiemensen die de afgelopen drie jaar niet aan een vervolgopleiding hebben deel genomen. 
Als we hierbij onderscheid maken tussen politiemensen die recentelijk wel of niet een vervolgopleiding hebben gevolgd, dan blijkt dat de prikkels beter lijken te werken op politiemensen die recentelijk géén vervolgopleiding gevolgd hebben. Alle prikkels werken dus relatief minder sterk op politiemensen die wel al recent aan een vervolgopleiding hebben deel genomen. Dit lijkt wellicht enigszins contra-intuïtief maar is het niet. Dat juist deze groep relatief minder op de prikkels reageert, betekent dat ze een hogere intrinsieke motivatie hebben tot het volgen van opleiding en minder extrinsiek geprikkeld hoeven worden. Dit blijkt uit Hoofdstuk 4 waarin we vonden dat 'learning-begets-learning': de verwachte toekomstige deelname aan vervolgopleidingen is namelijk significant groter onder politiemensen die de afgelopen drie jaar al aan een vervolgopleiding hebben deelgenomen. We kunnen hieruit een belangrijke conclusie trekken. Wanneer politiemensen in het recente verleden (laatste drie jaar) een vervolgopleiding hebben gevolgd, is hun intrinsieke motivatie om in de toekomst nog een vervolgopleiding te volgen relatief hoog. Als men eenmaal 'geproefd' heeft aan het leren, is men eerder geneigd nog meer te leren. Dit maakt het belangrijk om juist politiemensen die recentelijk niet aan een vervolgopleiding hebben deel genomen, weer te laten proeven aan het leren. Dat de bovengenoemde prikkels juist voor deze politiemensen relatief het beste lijken te werken is een aangename bevinding.

\subsection{Prikkels ter vergroting van het aantal zelfmelders}

Het blijkt dat prikkels die politiemensen stimuleren om aan een vervolgopleiding deel te nemen, ook de bereidheid verhogen dat politiemensen dit doen op (deels) eigen initiatief en/of met (gedeeltelijke) inzet van eigen tijd en/of geld. Dit wordt samengevat in Tabel 7.I. Deze tabel toont in aflopende volgorde alle relevante prikkels en daarnaast hoeveel procent van de geënquêteerde politiemensen als gevolg van de betreffende prikkels een hogere bereidheid aangeeft voor het nemen van eigen initiatief, het leren in eigen tijd en het betalen aan de te volgen vervolgopleiding.

\section{Tabel 7.1}

Prikkels en de toename van bereidheid tot eigen initiatief en inbreng, (percentage respondenten)

\begin{tabular}{|lllll|}
\hline & & \multicolumn{2}{l}{ Facetten van zelfmelden } & \\
& & $\begin{array}{l}\text { Eigen } \\
\text { initiatief }\end{array}$ & Eigen tijd & Eigen geld \\
\hline 1 & De opleiding leidt tot een hoger salaris binnen de huidige functie & $64 \%$ & $62 \%$ & $60 \%$ \\
\hline 2 & De opleiding wordt betaald door de werkgever & $63 \%$ & $61 \%$ & - \\
\hline 3 & De opleiding kan onder werktijd gevolgd worden & $61 \%$ & - & $50 \%$ \\
\hline 4 & Men mag een opleiding naar keuze volgen & $57 \%$ & $52 \%$ & $47 \%$ \\
\hline 5 & Er wordt een garantie geboden voor een baan passend bij de opleiding & $54 \%$ & $49 \%$ & $45 \%$ \\
\hline 6 & De opleiding kan modulair gevolgd worden & $34 \%$ & $36 \%$ & $31 \%$ \\
\hline 7 & De opleiding kan tijd/plaats onafhankelijk gevolgd worden & $34 \%$ & $22 \%$ & $16 \%$ \\
\hline
\end{tabular}

Bron: ROA enquête onder politiemensen 
De twee meest invloedrijke prikkels zijn monetair van aard. Een hoger salaris en een betaalde opleiding mogen volgen zijn beide voor een aanzienlijke meerderheid van de respondenten reden om in de toekomst meer bereid te zijn tot zelfmelden. Ook als men onder werktijd een vervolgopleiding mag volgen stijgt de bereidheid op de twee daarbij relevante facetten van zelfmelden bij minimaal de helft van de politiemensen. Het mogen volgen van een vervolgopleiding naar keuze of een garantie op een bij de opleiding passende functie hebben ook positief effect op de bereidheid tot zelfmelden van ongeveer de helft van de respondenten. Het aanbieden van flexibele onderwijsvormen zoals modulair opleiden en tijd- en plaats-onafhankelijk leren werkt veel minder stimulerend in de bereidheid tot (gedeeltelijk) zelfmelden, maar verhoogt deze bereidheid toch van ongeveer een derde van de respondenten.

De resultaten van het onderzoek tonen dat van de drie facetten van zelfmelden, de bereidheid tot het nemen van eigen initiatief relatief het meest beïnvloedbaar is. Daarentegen lijkt het iets minder gemakkelijk om politiemensen te stimuleren tot het opleiden in eigen tijd. Nog moeilijker wordt het om de bereidheid te beïnvloeden om een eigen financiële bijdrage te leveren aan de kosten van de opleiding. Dit kan te maken hebben met het scholingsbeleid tot nu toe. In Hoofdstuk 3 zagen we namelijk dat er momenteel nauwelijks door medewerkers meebetaald wordt aan een vervolgopleiding.

\subsection{Haalbaarheid van de prikkels}

De opleiding leidt tot een hoger salaris in huidige functie / de opleiding wordt betaald door de werkgever

Eén van de prikkels die bij de meeste politiemensen de bereidheid tot zelfmelden vergroot is als de opleiding door de werkgever betaald wordt. Echter, deze prikkel staat haaks op een van de drie facetten van zelfmelden die in dit onderzoek verkend worden: het (deels) op eigen kosten een opleiding volgen. Als we daarbij, gebaseerd op de diverse interviews en de focusgroep, van de realiteit uitgaan waarin opleidingsbudgetten onder druk staan, dan lijken monetaire prikkels zoals een door de werkgever betaalde opleiding of een hoger salaris in de huidige functie niet met deze realiteit verenigbaar. Hoewel de exacte kosten van de prikkels niet zijn berekend, kan met redelijke zekerheid worden gesteld dat deze monetaire prikkels relatief de grootste druk op de financiën binnen de politieorganisatie zullen leggen. In Hoofdstuk 2 zagen we al dat van de leidinggevenden die één of meerdere verzoeken tot het volgen een specialistische opleiding of functiegerichte applicatie hadden afgewezen, 38\% respectievelijk 50\% aangaf dat te hebben gedaan omdat het niet binnen het opleidingsbudget paste. Dit impliceert dat de implementatie van de prikkels 'meer salaris in de huidige functie' en 'de vervolgopleiding wordt betaald' een onrealistische toename van de financiële middelen binnen de eenheden vereist. De conclusie is daarom op 
het eerste oog dat deze eerste twee prikkels uit Tabel 7.I niet binnen het huidige politiebeleid passen.

Toch stijgt van ruim zestig procent van de geënquêteerde politiemensen de bereidheid om eigen initiatief en/of tijd in een vervolgopleiding te investeren als deze maar door de werkgever betaald wordt. Dit lijkt de mogelijkheid te bieden om zelfmelden in ieder geval flink te stimuleren op de facetten van eigen initiatief en tijd. In feite is dit een uitruilscenario waar men bij een grote zorginstelling in de Randstad al ervaring mee heeft. Daar is men tot de conclusie gekomen dat het voor de organisatie veel kostbaarder is om een medewerker vrij te roosteren voor opleidingen dan om de directe monetaire opleidingskosten te betalen. Om die reden hebben ze ervoor gekozen om vooral in te zetten op het verhogen van de bereidheid van medewerkers om in eigen tijd een opleiding te volgen. Enkel wanneer een medewerker ook duidelijk zelf baat heeft bij een opleiding, wordt ook een financiële bijdrage van de medewerker gevraagd. Het gaat dan om opleidingen waarmee de brede arbeidsmarktmogelijkheden van de medewerker, ook buiten de betreffende zorginstelling, sterk vergroot worden.

\section{De opleiding kan onder werktijd gevolg worden}

Het volgen van een opleiding onder werktijd is een prikkel die eveneens relatief hoge percentages van de geënquêteerde politiemensen beweegt tot een hogere bereidheid om in de toekomst eigen initiatief te tonen en/of (mee) te betalen aan een vervolgopleiding. Echter, hoewel deze prikkel blijkt te werken ten aanzien van die twee facetten van zelfmelden, behelst deze prikkel juist het omgekeerde van wat met dit onderzoek verkend wordt: dat politiemensen ook meer in eigen tijd vervolgopleidingen gaan volgen. Op zijn best kan met deze prikkel dus een uitruil teweeg worden gebracht waarbij een aanzienlijk deel van de politiemensen wel meer initiatief bereid is te tonen en zelf wil (mee)betalen, maar dan alsnog onder werktijd de vervolgopleiding wil volgen.

\section{Men mag een opleiding naar keuze volgen}

In Hoofdstuk 2 zagen we dat ongeveer de helft van de leidinggevenden aangeeft de afgelopen drie jaar geen enkel opleidingsverzoek te hebben afgewezen. Dit impliceert dat deze leidinggevenden de keuze van hun medewerkers voor de te volgen vervolgopleidingen niet belemmeren, wat positief is voor de prikkel 'men mag een vervolgopleiding naar keuze volgen'. Desalniettemin zou de vereiste toestemming van de leidinggevende(n) op zichzelf het gevoel van keuzevrijheid kunnen belemmeren. De optimale invoering van de prikkel 'keuzevrijheid' zou daarom inhouden dat de tussenkomst van de leidinggevende(n) niet langer vereist is bij de inschrijvingen voor bepaalde vervolgopleidingen. Hiermee is echter nog niet de vraag beantwoord wie dan de opleiding betaalt en in wiens tijd deze wordt gevolgd. Echter, de prikkel keuzevrijheid heeft telkens voor ongeveer de helft van de politiemensen een positief effect 
op de bereidheid om eigen tijd in de opleiding te steken en op bereidheid om eigen geld in de opleiding te investeren. De prikkel 'keuzevrijheid' lijkt daarmee kansrijk om in de toekomst tot meer zelfmelders te komen. Het is dan wel van belang dat de opleiding dermate flexibel wordt aangeboden, dat deze ook in de eigen tijd van de medewerker gevolgd kan worden.

\section{Er wordt een garantie geboden voor een baan passend bij de opleiding}

Uit de interviews is gebleken dat vervolgopleidingen tot op heden niet zelden gekoppeld waren aan een promotie of een functieverandering. Achter de wens om in de toekomst meer politiemensen op eigen initiatief en voor eigen rekening een vervolgopleiding te laten volgen, schuilt de gedachte dat politiemensen daardoor hun keuzes voor vervolgopleidingen op meer intrinsieke gronden maken. Het wordt steeds minder wenselijk geacht dat de motivatie om aan een vervolgopleiding deel te nemen extrinsiek gedreven is. De prikkel van een garantie op een bij de opleiding passende baan lijkt dan ook niet te passen in de beweging van een rechtspositioneel naar een ontwikkelingsgericht personeelsbeleid.

\section{De opleiding kan modulair gevolgd worden / de opleiding kan tijd/plaats onafhankelijk gevolgd worden}

Uit diverse interviews, bijeenkomsten en de focusgroep met beleidsdeskundigen is gebleken dat de Politieacademie positief staat tegenover het aanbieden van meer modulair onderwijs en de toepassing van e-learning onderwijsvormen. E-learning maakt onderwijs tijd- en plaats onafhankelijk. Daarnaast leggen deze prikkels naar alle waarschijnlijkheid relatief de minste druk op de budgets. Het voorbeeld uit de zorgsector op pagina 76 , toont daarnaast dat medewerkers door toepassing van e-learning voor kenniscomponenten van opleidingen niet vrij geroosterd hoeven te worden. Dit leidt tot minder bezettingsproblemen.

\subsection{Slotconclusies}

De prikkels die uitgaan van flexibilisering van het politieonderwijs, modulair onderwijs en tijd/plaats onafhankelijk onderwijs, blijken ten opzichte van de andere prikkels relatief weinig politiemensen te bewegen tot een grotere bereidheid tot eigen initiatief of inbreng in tijd of geld. Desondanks moet de potentie van de eerstgenoemde prikkels niet worden onderschat. Het juiste referentiekader is namelijk niet de effectiviteit van de andere hoofdzakelijk extrinsieke monetaire prikkels. Het referentiekader is de bestaande situatie waarin vervolgopleidingen doorgaans worden geïnitieerd en betaald door de werkgever en in werktijd mogen worden gevolgd. Dit is de 'ist' situatie waarin het onderzoek heeft plaatsgevonden en waaraan de organisatie en haar medewerkers gewend is. De eerste conclusie luidt: 
Politiemensen zijn als gevolg van het bestaande beleid rondom vervolgopleidingen gewend om op extrinsieke gronden aan vervolgopleidingen deel te nemen. De 'soll' situatie, waarin meer politiemensen als (gedeeltelijk) zelfmelder aan opleidingen deelnemen, staat ver af van de situatie waaraan politiemensen en organisatie tot op heden gewend zijn.

Met deze 'ist' situatie als uitgangspunt, is het onwaarschijnlijk dat er nieuwe prikkels bloot te leggen zijn die een grote meerderheid van de politiemensen ineens blijken te motiveren om zelf tijd te gaan steken in een opleiding of te betalen voor een opleiding. Het is in die zin juist een bevestiging van de gewenning aan de huidige situatie, dat de extrinsiek motiverende prikkels die gebaseerd zijn op geld en tijd bij zoveel van de geënquêteerde politiemensen effect sorteren. In dit licht, is de bijzonder positieve en hoopvolle tweede conclusie:

Flexibele onderwijsvormen, zoals meer modulair onderwijs en tijd-en plaats onafhankelijk onderwijs aanbieden, vergroten van maar liefst een derde van de politiemensen de bereidheid om als (gedeeltelijk) zelfmelder in de toekomst een vervolgopleiding te gaan volgen.

Hiermee blijkt dat ondanks gewenning aan het huidige extrinsiek gemotiveerde opleidingsbeleid, toch een aanzienlijk deel van de politiemensen al op de intrinsieke prikkels reageert.

Daarnaast toont het onderzoek aan dat er een uitruil mogelijk is tussen diverse facetten van zelfmelden. Het zou bijzonder ambitieus zijn en gezien de onderzoeksresultaten weinig realistisch, om van een situatie zonder zelfmelders te willen gaan naar een situatie met een groot aantal politiemensen die én volledig het eigen initiatief nemen voor een vervolgopleiding, én deze volledig zelf betalen én volledig in eigen tijd volgen. Het lijkt wel mogelijk om, als eerste stap in deze richting, meer politiemensen bereid te vinden om bijvoorbeeld meer eigen initiatief en tijd in een vervolgopleiding te investeren, als deze wel nog door de werkgever betaald wordt. Ruim $60 \%$ van de politiemensen is dan namelijk bereid om een opleiding in eigen tijd of op eigen initiatief te volgen. Deze uitruil - de opleiding wordt door de werkgever betaald, maar in eigen tijd van de werknemer gevolgd - wordt in de zorg al toegepast, zoals het voorbeeld op pagina 94 toont. De derde conclusie luidt daarom:

\section{Zelfmelden kan bij ruim 60\% van de politiemensen gestimuleerd worden op de facetten 'eigen initiatief' en/of 'eigen tijd', als de politie de opleiding betaalt. Dit kan complementair zijn aan het stimuleren van zelfmelders door middel van modulair en tijd-en plaats onafhankelijk onderwijs.}

Het onderzoek toont dus aan dat er diverse in de realiteit toe te passen prikkels zijn waarmee politiemensen gestimuleerd kunnen worden om in de toekomst als zelfmelder een vervolgopleiding te gaan volgen. De flexibele onderwijsvormen modulair 
en tijd- en plaats onafhankelijk onderwijs zijn hierbij de twee prikkels die het minste druk op budgets lijken te leggen en daarbij de intrinsieke motivatie van politiemensen aanspreekt.

De leidinggevenden lijken daarbij al in redelijke mate klaar te zijn voor een situatie waarin meer politiemensen eigen initiatief gaan nemen voor het volgen van vervolgopleidingen. Diverse resultaten wijzen daarop. In Hoofdstuk 2 zagen we dat ongeveer de helft van de leidinggevenden aangaf de afgelopen drie jaar geen enkel opleidingsverzoek te hebben afgewezen. Als men wel een opleidingsverzoek afwees, was dit meestal om budgettaire redenen en minder vaak om inhoudelijke redenen. Dit duidt op een open houding voor het verzoek van de medewerker. Daarnaast toonde Hoofdstuk 2 dat leidinggevenden van mening zijn dat het initiatief voor de meeste soorten vervolgopleidingen, significant meer aan de kant van de medewerker moet liggen dan bij de leidinggevende. Dit geeft aan dat leidinggevenden al niet meer van mening zijn dat louter zij bepalen wie, wanneer, welke opleiding mag volgen. Toch voelt ongeveer de helft van de medewerkers zich nog onvoldoende gesteund door de leidinggevende als het gaat om loopbaanmogelijkheden en toezeggingen daaromtrent. Dit leidt tot de vierde conclusie:

Al met al lijken de leidinggevenden in redelijke mate de juiste instelling te hebben om met de zelfmelders van de toekomst om te gaan, maar komt dit in de beleving van de medewerkers in de praktijk nog niet volledig uit de verf.

Hoeveel bereidheid tot eigen initiatief en eigen inbreng in tijd en geld in de toekomst ook te bewerkstelligen is onder politiemensen, het zal breed gedragen moeten worden door de leiding. Uit interviews met onderwijsdeskundigen zowel uit de zorg als uit het onderwijs, blijkt dat het daarbij van cruciaal belang is dat concreet en consistent, top-down de insteek uitgedragen én toegepast moet worden, dat training en opleiding iets is waarbij ook medewerkers het initiatief kunnen nemen. 



\section{Bijlage A De steekproef}

In deze bijlage wordt allereerst een overzicht gegeven van het aantal respondenten naar leeftijd en geslacht. Dit wordt vergeleken met populatie-gegevens uit administratieve bronnen om uitspraken te kunnen doen over de representativiteit van de respons. Vervolgens tonen we de respons verdeeld naar rang en domein. Vanwege definitieverschillen konden we deze niet één op één vergelijken met populatie-gegevens.

\section{Respons en representativiteit}

De enquête is verstuurd naar 2.4II politiemedewerkers. I.230 politiemedewerkers hebben de vragenlijst (gedeeltelijk) ingevuld. Echter I86 personen gaven aan een rang te hebben die te ver weg stond van de - voor dit onderzoek - relevante groep politiemedewerkers. Voorbeelden zijn ondersteunend personeel en burgers. De uiteindelijke respons waarop het rapport is gebaseerd betreft daarom I.044 politiemedewerkers. Dit komt neer op een bruikbare respons van $43 \%$.

Om in te gaan op de representativiteit vergelijken wij onze respons met populatiegegevens afkomstig uit de Politie Beleids Informatie Systemen (PolBIS). Vanuit PolBIS hebben wij een verdeling van de Operationele Sterkte ontvangen naar leeftijd en geslacht per ultimo 2012 .

Figuur A.I toont dat $86 \%$ van de respondenten in onze steekproef man is. Dit is hoger dan in de populatie op basis van PolBIS. Navraag bij de uitvoerend instantie van het Flitspanel (MWM2) leert echter dat mannen oververtegenwoordigd zijn in het Flitspanel voor de sector politie. Tevens is het aandeel medewerkers ouder dan 45 jaar in het Flitspanel voor de sector politie oververtegenwoordigd. Figuur A.2 toont dat ook onze respons vanaf een leeftijd van 50 jaar een aanzienlijke oververtegenwoordiging kent. In de leeftijdscategorieën 40-44 en 45-49 wijkt de respons weinig af van de populatie. De leeftijdscategorieën onder de 40 jaar zijn in onze respons ondervertegenwoordigd. De ondervertegenwoordiging van vrouwen en politiemensen jonger dan 40 is dus al aanwezig in het Flitspanel voor de sector politie. Er is daarmee geen sprake van selectieve non-respons ten opzichte van onze vragenlijst. Wel moeten wij hieruit concluderen dat onze resultaten met voorzichtigheid geïnterpreteerd moeten worden als het gaat om politiemensen jonger dan 40 jaar en vrouwelijke politiemensen. 
Figuur A.1

Verdeling naar geslacht, steekproef ten opzichte van populatie

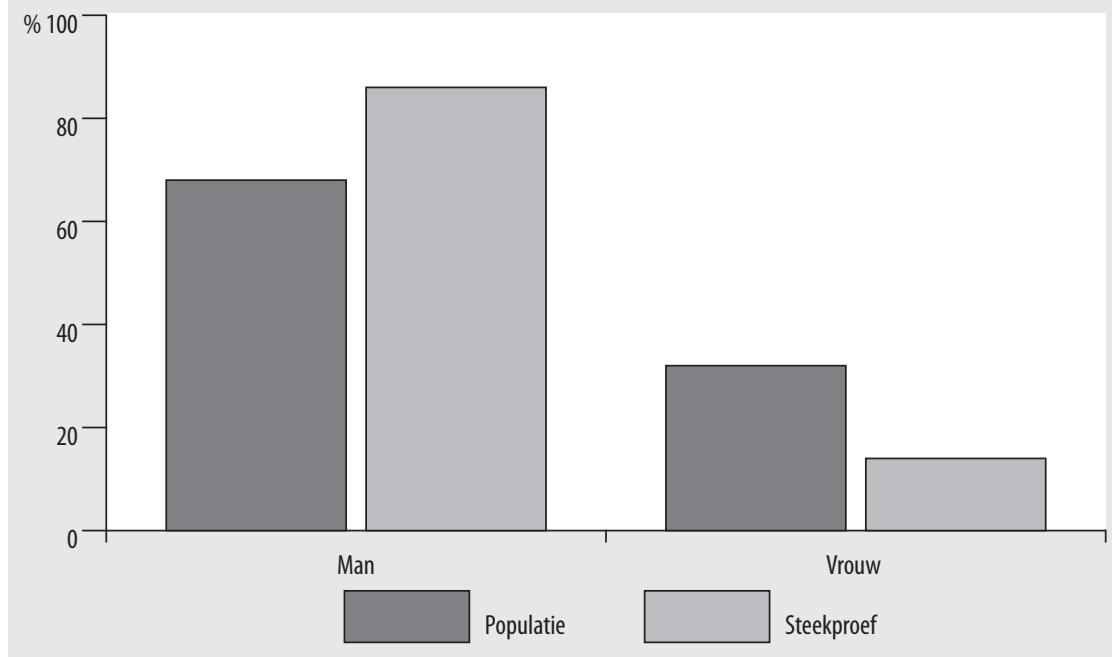

Bron: ROA enquête onder politiemedewerkers en PolBIS

Figuur A.2

Verdeling naar leeftijd, steekproef ten opzichte van populatie

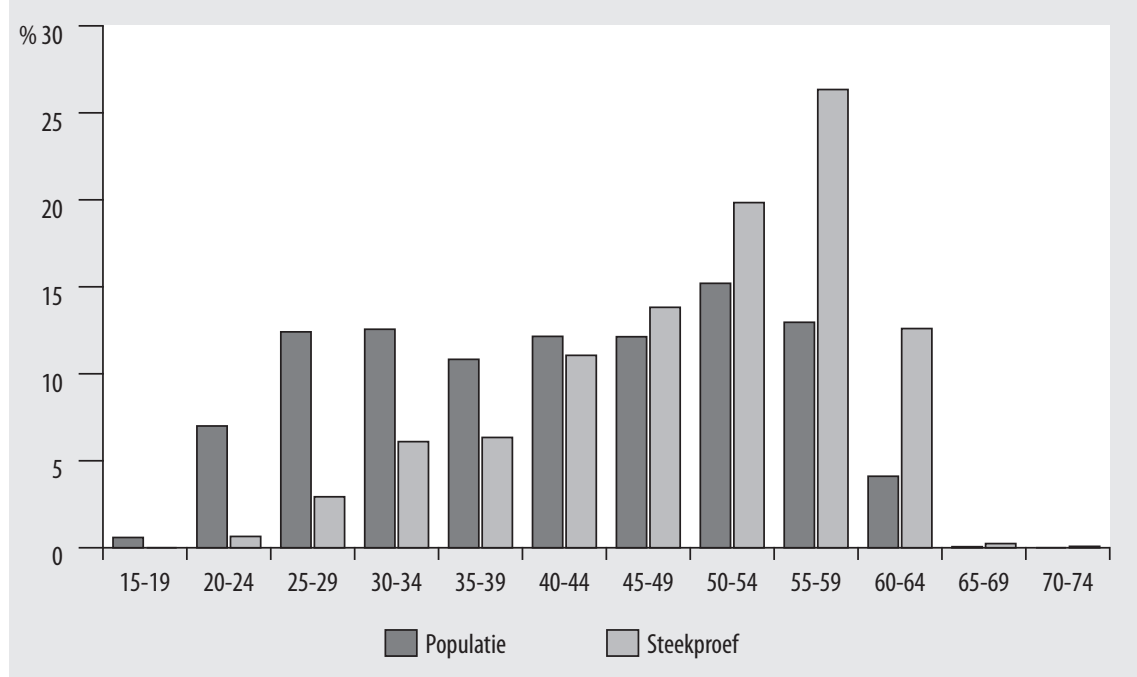

Bron: ROA enquête onder politiemedewerkers en PolBIS 


\section{Verdeling steekproef naar rang, domein en leidinggevende functie}

Het aantal respondenten is erg verschillend tussen rangen. Terwijl meer dan $35 \%$ van de respondenten brigadier is, heeft er maar I hoofdcommissaris meegedaan aan de enquête. Er hebben ook relatief veel inspecteurs en hoofdagenten aan de vragenlijst deelgenomen (25 en $17 \%$ respectievelijk).

\section{Figuur A.3}

Verdeling respondenten naar rang

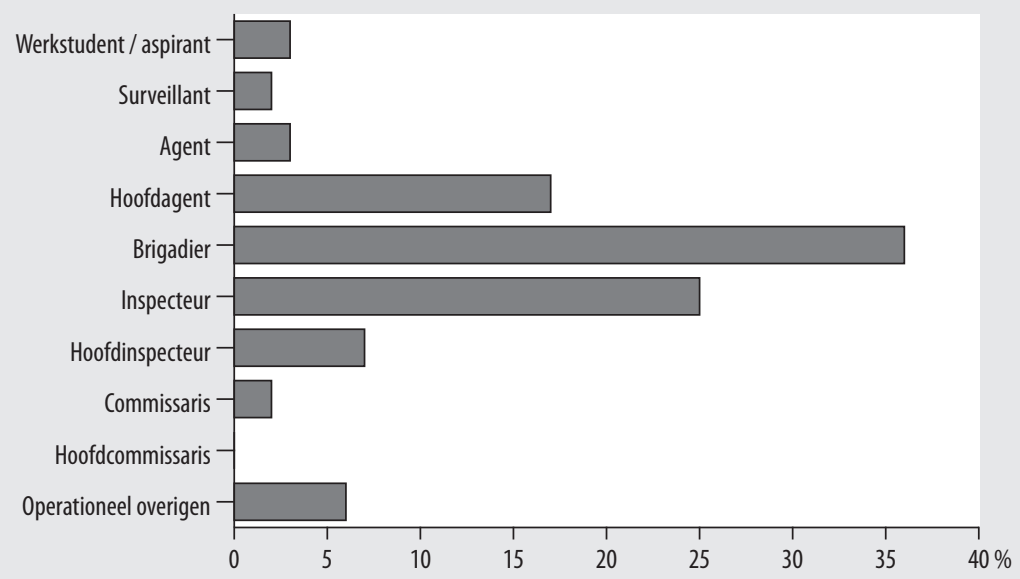

Bron: ROA enquête onder politiemedewerkers

Het aantal respondenten blijkt ook uiteen te lopen tussen domeinen. Het domein dat het meeste vertegenwoordigd is blijkt de basispolitiezorg. $4 \mathrm{I} \%$ van alle respondenten is in dit domein werkzaam. Er zijn ook relatief veel respondenten binnen het domein 'opsporing en informatie' (35\%). Er zijn duidelijk minder respondenten onder de andere vier domeinen. 


\section{Figuur A.4}

Verdeling respondenten naar domein

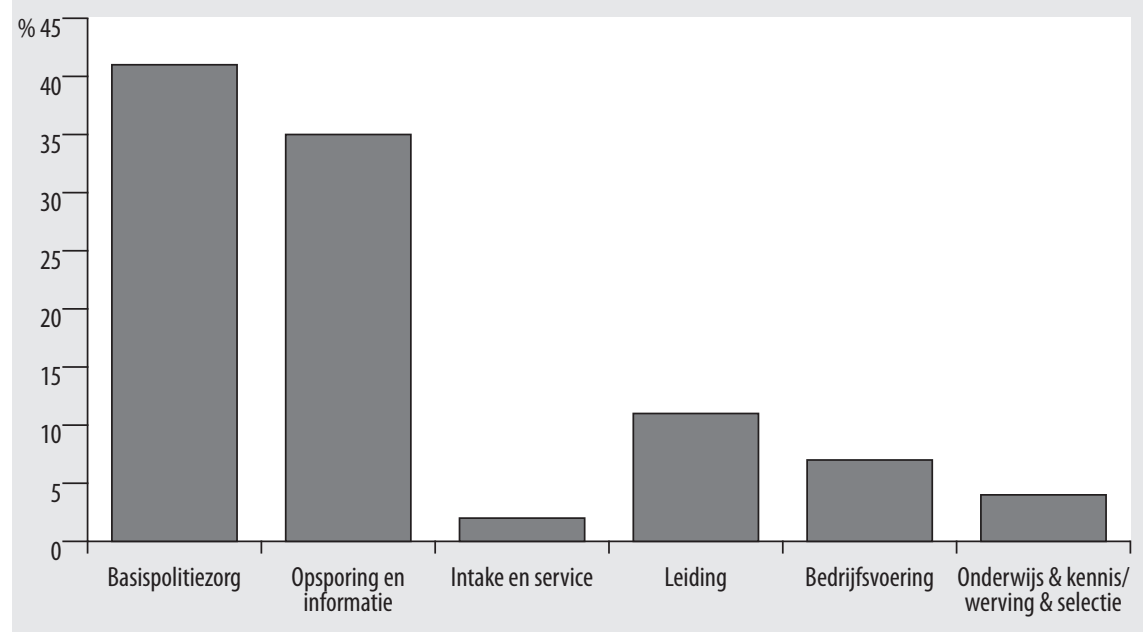

Bron: ROA enquête onder politiemedewerkers

In de vragenlijst is tevens onderscheid gemaakt tussen leidinggevenden en nietleidinggevenden. $32 \%$ van de respondenten blijkt een leidinggevende functie met personele verantwoordelijkheid te hebben. 


\section{Bijlage B De invloed van persoonlijkheids- kenmerken op zelfmelden bij de laatst gevolgde vervolgopleiding}

In deze bijlage bekijken we in hoeverre medewerkers die bij hun laatst gevolgde vervolgopleiding een (gedeeltelijke) zelfmelder waren en degenen die een niet-zelfmelder waren van elkaar verschillen wat betreft persoonlijkheidskenmerken. We gaan eerst in op vier economische voorkeuren: risicovoorkeur, positieve reciprociteit, negatieve reciprociteit, en tijdsvoorkeur. Deze persoonlijkheidskenmerken zijn gemeten door de respondenten een aantal stellingen voor te leggen en te vragen in hoeverre deze stellingen hen als persoon beschrijven. De antwoorden konden worden gegeven op een schaal van o tot IO, van "zo ben ik echt niet" tot "zo ben ik echt". ${ }^{33}$ In Tekstbox B.I is een overzicht gegeven van de persoonlijkheidskenmerken en de bijbehorende stelling.

Tekstbox B.1

\begin{tabular}{|c|c|}
\hline Persoonlijkheidskenmerk & Stelling \\
\hline Risicovoorkeur & In het algemeen ben ik iemand die bereid is risico's te nemen \\
\hline Positieve reciprociteit & Als iemand mij een plezier doet, dan ben ik bereid om iets terug te doen \\
\hline Negatieve reciprociteit & $\begin{array}{l}\text { Als mij ernstig onrecht wordt aangedaan, dan zal ik kosten noch moeite sparen om wraak te } \\
\text { nemen. }\end{array}$ \\
\hline Tijdsvoorkeur & $\begin{array}{l}\text { Ik ben van nature iemand die bereid is om vandaag van iets af te zien om daar later voordeel } \\
\text { van te hebben. }\end{array}$ \\
\hline
\end{tabular}

Tekstbox B.I toont of persoonlijkheidskenmerken van invloed zijn geweest op het gegeven of iemand zijn meest recente vervolgopleiding volledig of gedeeltelijk als zelfmelder heeft gevolgd. De panels geven naast de relatie tussen de persoonlijkheidskenmerken en zelfmelden, ook een beeld van de verdeling van de persoonlijkheidskenmerken an sich.

De meest in het oog springende panels zijn (a) en (b), de panels van risicovoorkeur en positieve reciprociteit. Iemand die een Io aangeeft bij risicovoorkeur, is risico minnend en dus erg bereid risico's te nemen. Iemand die daarentegen een I aangeeft, is erg risicoavers en zal proberen risico's te vermijden. ${ }^{54}$ Iemand die een Io aangeeft bij positieve reciprociteit is bijzonder bereid een goede daad van een andere met een

53. Dohmen et al. (in mimeo) An Experimentally Validated Preference Module.

54. We hebben in de figuur alleen het gemiddelde percentage politiemensen aangegeven dat bij de laatst gevolgde vervolgopleiding een (gedeeltelijke) zelfmelder is geweest indien er minimaal io politiemensen het desbetreffende persoonlijkheidskenmerk hebben aangegeven. Daardoor zijn in Figuur B.I a en b niet alle scores op de $\mathrm{x}$-as opgenomen. 
goede daad te beantwoorden. In Panel (a) is te zien dat er nauwelijks respondenten zijn die bijzonder risicoavers zijn. Aangezien het politievak een van de risicoberoepen is, is het logisch dat er nauwelijks respondenten zijn die totaal niet van risico houden. Panel (b) toont dat de respondenten over het algemeen positief wederkerig zijn. Tot slot blijkt uit geen van de vier panels een significante relatie tussen een van de persoonlijkheidskenmerken met of iemand bij de laatst gevolgde vervolgopleiding (gedeeltelijke) zelfmelder is geweest.

\section{Figuur B.1}

Zelfmelders (al dan niet volledig) en economische voorkeuren
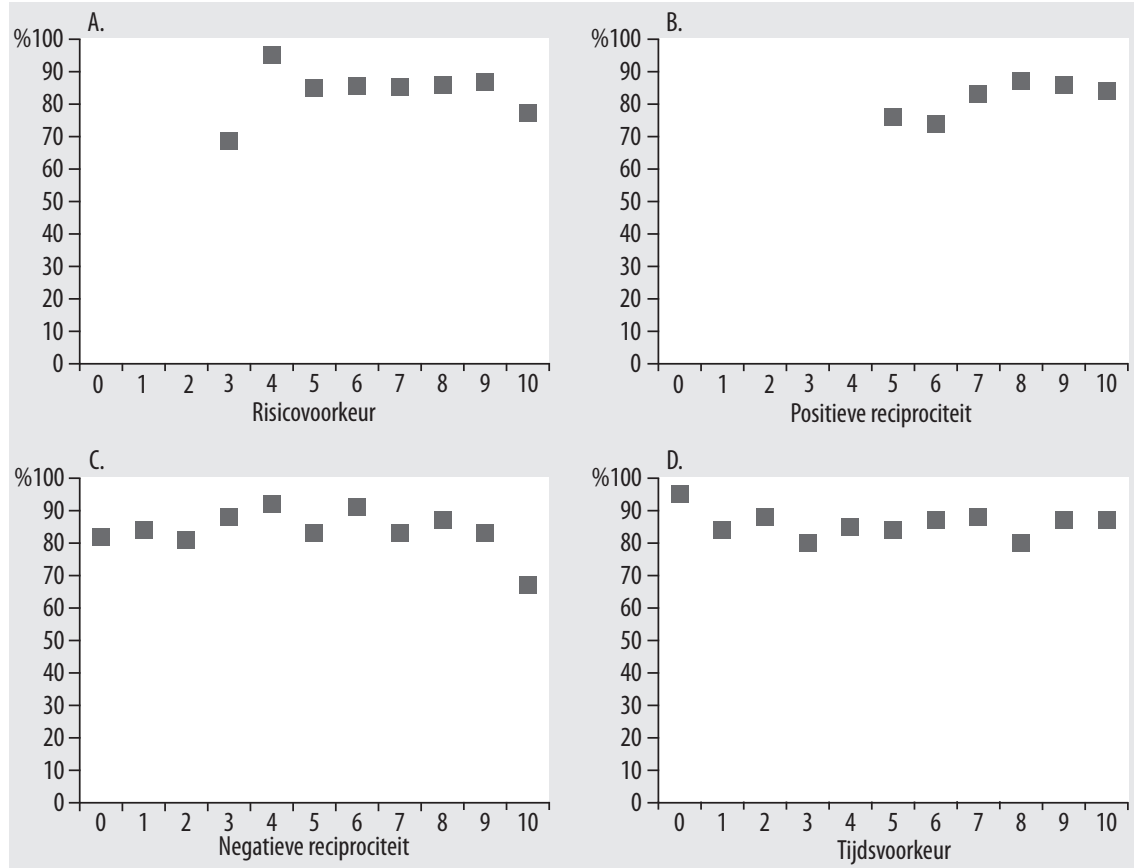

Bron: ROA enquête onder politiemensen

Naast de hierboven geanalyseerde (economische) voorkeuren zijn er nog andere persoonlijkheidskenmerken die gerelateerd zouden kunnen zijn aan of iemand een (gedeeltelijke) zelfmelder is geweest. We gaan in op p: $^{55}$

- De mate waarin iemand zich verantwoordelijk voelt voor het bezitten van de kennis en vaardigheden die nodig zijn voor de huidige functie en de verdere ontwikkeling. ${ }^{56}$

- De mate waarin iemand het leuk vindt om nieuwe dingen te leren.

55. Deze items zijn op een vijf-puntsschaal gemeten.

56. Dit waren twee aparte uitspraken waarvoor politiemensen in hoeverre deze van toepassing op hun waren. We hebben een gemiddelde genomen. 
- De mate waarin iemand een duidelijk beeld heeft over hoe hij/zij zichzelf wil ontwikkelen en zichzelf doelen stelt. ${ }^{57}$

In Figuur B.2 is op een indirecte manier te zien in hoeverre politiemensen (a) zich verantwoordelijk voelen voor het bezitten van de kennis en vaardigheden die nodig zijn voor de huidige functie en de verdere ontwikkeling, (b) het leuk vinden om nieuwe dingen te leren, (c) een duidelijk beeld hebben in hoe zij zich willen ontwikkelen en hoe zij zichzelf doelen stellen. ${ }^{58}$ Bovendien is in de figuur aangegeven wat het percentage politiemensen is dat per antwoordcategorie aangeeft bij de laatst gevolgde vervolgopleiding een (gedeeltelijke) zelfmelder te zijn geweest.

\section{Figuur B.2}

Zelfmelders (al dan niet volledig) en andere persoonlijkheidskenmerken

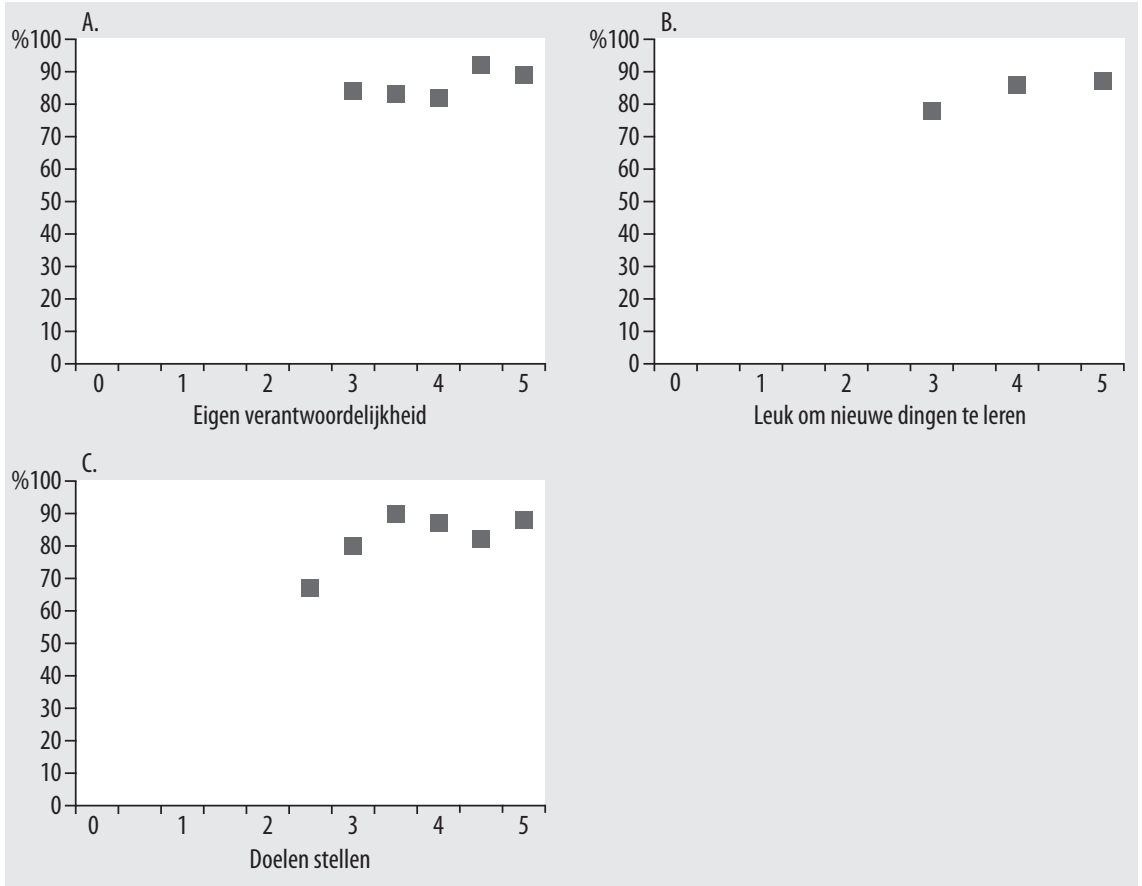

Bron: ROA enquête onder politiemensen

Uit de ontbrekende scores op de $\mathrm{x}$-as is af te leiden dat de respondenten over het algemeen een redelijk groot eigen verantwoordelijkheidsgevoel hebben voor het bezitten van kennis en vaardigheden die nodig zijn voor de huidige functie en verdere ontwikkeling, dat ze het leuk vinden om te leren, en dat ze over het algemeen een redelijk duidelijk beeld hebben over hoe ze zichzelf willen ontwikkelen en zichzelf doelen

57. Dit waren twee aparte uitspraken waarvoor politiemensen in hoeverre deze van toepassing op hun waren. We hebben een gemiddelde genomen.

58. Dit is wederom te zien doordat sommige antwoordcategorieën minder dan Io politiemensen bevatten. 
stellen. Hoewel de correlatie niet groot is, is er sprake van een significante positieve relatie tussen de mate waarin respondenten een gevoel hebben van eigen verantwoordelijkheid voor het bezitten van de nodige kennis en vaardigheden en of ze bij de laatst gevolgde vervolgopleiding een (gedeeltelijke) zelfmelder waren (Panel a). Ook is er een kleine maar significant positieve relatie tussen de mate waarin men het leuk vindt om te leren en (gedeeltelijk) zelfmelderschap (Panel b). ${ }^{59} \mathrm{Er}$ is geen significant relatie met de mate waarin men een duidelijk beeld heeft in hoe zij zich willen ontwikkelen en hoe zij zichzelf doelen stellen en zelfmelden (hoewel dit op basis van de figuur wel zo lijkt te zijn).

59. Het feit dat de correlaties klein (maar significant) zijn heeft te maken met de relatief geringe spreiding in de persoonlijkheidsvariabelen. 


\section{Bijlage C Persoonlijkheidskenmerken en de verwachte toekomstige deelname aan vervolgopleidingen}

In deze bijlage bekijken we of de verwachte deelname aan vervolgopleidingen onder politiemensen ook gerelateerd is aan een aantal persoonlijkheidskenmerken. We gaan eerst in op de vier economische voorkeuren die in Bijlage B ook al aan bod kwamen: risicovoorkeur, positieve reciprociteit, negatieve reciprociteit, en tijdsvoorkeur. In Figuur C.I is de relatie tussen de verwachte deelname aan een vervolgopleiding en de mate van risicovoorkeur weergegeven. Iemand die een Io heeft aangegeven is erg bereid risico's te nemen. Iemand die daarentegen een I heeft aangegeven, is erg risicoavers en zal proberen risico's te vermijden. ${ }^{60}$

\section{Figuur C.1}

Verwachte deelname aan vervolgopleidingen en risicovoorkeur
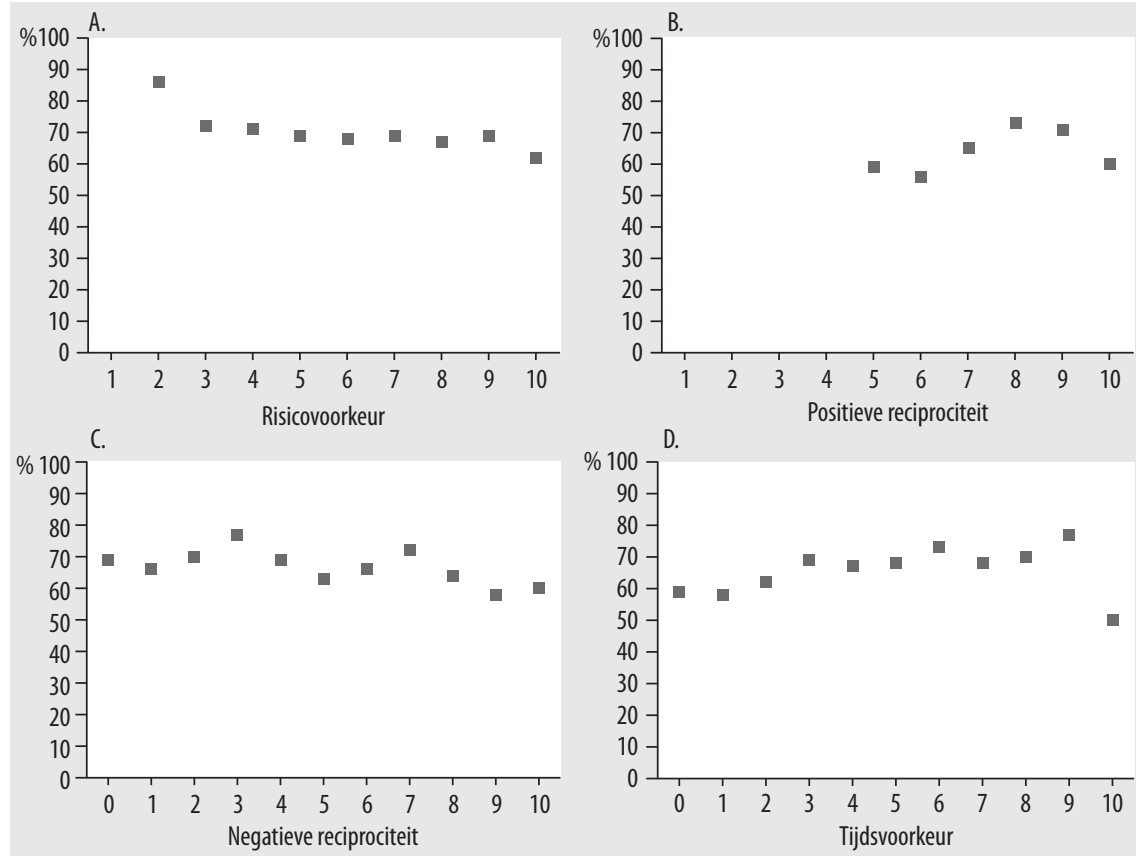

Bron: ROA enquête onder politiemensen

6o. We hebben in de figuur de verwachte deelname aan een vervolgopleiding in de komende vijf jaar, alleen weergegeven indien er minimaal 20 politiemensen waren binnen de desbetreffende risicovoorkeursgroep. Daardoor zijn risicovoorkeursgroep o en I niet in de figuur opgenomen. 
We zien een negatieve relatie tussen de verwachte deelname aan vervolgopleidingen en risicovoorkeur. Dit wil zeggen dat politiemensen die in hoge mate bereid zijn risico's te nemen over het algemeen minder vaak denken binnen vijf jaar een vervolgopleiding te gaan volgen. Echter, deze negatieve relatie blijkt niet sterk te zijn. ${ }^{6 r}$

In Panels (b) en (c) zijn de relaties tussen aan de ene kant de verwachte deelname aan vervolgopleidingen en aan de andere kant de positieve en negatieve reciprociteit weergegeven. Hoe hoger de score van positieve reciprociteit hoe meer personen zich kunnen vinden in de stelling "als iemand mij een plezier doet, dan ben ik bereid om iets terug te doen". Er wordt vaak gevonden dat mensen die positief wederkerig zijn, meer job effort leveren (e.g., Brown et al. 2004). ${ }^{62}$ Uit Panel (b) blijkt echter dat er geen eenduidige relatie te zien is tussen de mate van positieve reciprociteit en de verwachting dat men binnen vijf jaar een vervolgopleiding gaat volgen. ${ }^{63}$ Dit is tegenstelling tot Panel (c) waarin deze verwachting wordt gerelateerd aan negatieve reciprociteit. Mensen die erg negatief wederkerig zijn ingesteld, verwachten minder vaak binnen vijf jaar een vervolgopleiding te gaan volgen. Toch blijkt ook hier dat de relatie tussen de mate waarin iemand negatief wederkerig is en de verwachtingen ten aanzien van het volgen van een vervolgopleiding binnen de komende vijf jaar erg zwak is.

Er zijn duidelijke theoretische verwachtingen met betrekking tot de relatie tussen investeringen in het menselijk kapitaal, zoals vervolgopleidingen en tijdsvoorkeuren. Omdat vervolgopleidingen tijd en geld kosten en de baten ervan (bijvoorbeeld in de vorm van een hoger salaris of een interessantere baan) vaak pas later zichtbaar zijn, is de voorspelling dat mensen die relatief veel waarde hechten aan het nu, en minder aan de toekomst, minder aan vervolgopleidingen zullen deelnemen. In Panel (d) zien we dat de relatie tussen de verwachte deelname aan vervolgopleidingen en tijdsvoorkeur inderdaad in lijn is met deze voorspelling. Politiemensen die een lage waarde aangeven hechten relatief veel waarde aan het nu in vergelijking met mensen die een hoge waarde aangeven. In lijn met de beschreven hypothese is het percentage mensen dat aan een vervolgopleiding denkt deel te nemen lager onder de mensen die relatief veel waarde hechten aan het nu. 59\% van de mensen die aangeven zich helemaal niet te kunnen vinden in de stelling gerapporteerd in Tekstbox B.I (score o op de x-as), verwacht binnen vijf jaar een vervolgopleiding te volgen. Dit percentage stijgt tot $77 \%$ onder de mensen die aangeven zich erg te kunnen vinden in de stelling (score 9

6I. De observatie dat risicovoorkeuren niet significant gerelateerd zijn aan (geplande) deelname aan vervolgopleidingen vinden we ook terug voor werkend Nederland in het algemeen (Borghans et al. 20II).

62. Brown, et al. (2004), 'Relational contracts and the nature of market Interactions', Econometrica 72 , 747-780. Er zijn ons echter geen studies bekend die reciprociteit relateren aan de (verwachte) deelname aan vervolgopleidingen vanuit het werknemersperspectief. Leuven et al. (2005) hebben aangetoond dat werkgevers meer bereid zijn om in werknemers te investeren door hen vervolgopleidingen aan te bieden als de werknemer wederkerig is (Leuven et al. (2005), 'Worker Reciprocity and Employer Investment in Training', Economica, 72, I37-I49).

63. Er zijn te weinig politiemensen die maar (zeer) beperkt positief wederkerig zijn om een gemiddelde te kunnen weergeven met betrekking tot hun verwachte deelname aan vervolgopleidingen. 
op de x-as). Echter, we observeren een uitzondering onder de mensen die aangegeven hebben echt zo te zijn, zoals de stelling weergeeft (score Io op de x-as). Onder deze mensen vinden we dat iets minder dan de helft van hen aangeeft dat zij verwachten een vervolgopleiding te gaan volgen binnen de komende vijf jaar. Waarschijnlijk vinden we hierdoor dat de relatie tussen tijdsvoorkeuren en de verwachte deelname aan vervolgopleidingen slechts zeer zwak gecorreleerd zijn. Deze niet-significante relatie tussen (geplande) deelname aan vervolgopleidingen en een maatstaf voor tijdsvoorkeur is ook gevonden voor de gemiddelde Nederlandse werknemer (Borghans et al. 20II).

Naast de hierboven geanalyseerde economische voorkeuren - risicovoorkeur, reciprociteit en tijdsvoorkeur - bespreken we nog drie andere persoonlijkheidskenmerken die gerelateerd zouden kunnen zijn aan de verwachte deelname aan een vervolgopleiding in de nabije toekomst.

- De mate waarin iemand zich verantwoordelijk voelt voor het bezitten van de kennis en vaardigheden die nodig zijn voor de huidige functie en de verdere ontwikkeling. ${ }^{64}$

- De mate waarin iemand het leuk vindt om nieuwe dingen te leren.

- De mate waarin iemand een duidelijk beeld heeft over hoe hij/zij zichzelf wil ontwikkelen en zichzelf doelen stelt. ${ }^{65}$

In Figuur C. 2 is op indirecte wijze te zien in hoeverre politiemensen (a) zich verantwoordelijk voelen voor het bezitten van de kennis en vaardigheden die nodig zijn voor de huidige functie en de verdere ontwikkeling, (b) het leuk vinden om nieuwe dingen te leren, (c) een duidelijk beeld hebben in hoe zij zich willen ontwikkelen en hoe zij zichzelf doelen stellen. ${ }^{66}$ Bovendien is in de figuur aangegeven wat het percentage politiemensen is dat per antwoordcategorie aangeeft te verwachten binnen vijf jaar een vervolgopleiding te gaan volgen. In Panel (a) zien we dat er maar weinig mensen zijn (minder dan 20) die zich helemaal niet of nauwelijks verantwoordelijk voelen voor de kennis en vaardigheden die zij nu nodig hebben of in hun verdere ontwikkeling kunnen gebruiken. De meeste politiemensen geven aan dat zij zelf erg of heel erg verantwoordelijk zijn voor het bezitten van deze kennis en vaardigheden. We zien echter geen eenduidige relatie tussen de mate waarin iemand zich verantwoordelijk voelt voor het bezitten van deze kennis en vaardigheden en de verwachting dat ze binnen vijf jaar een vervolgopleiding gaan volgen. Dit is anders in Panel (b). Ook hier zien we dat de antwoordcategorie (uitspraak helemaal niet van toepassing op mij) nauwelijks is ingevuld. De meeste politiemensen geven aan het (erg) leuk te vinden

64. Dit waren twee aparte uitspraken waarvoor politiemensen in hoeverre deze van toepassing op hun waren. We hebben een gemiddelde genomen.

65. Dit waren twee aparte uitspraken waarvoor politiemensen in hoeverre deze van toepassing op hun waren. We hebben een gemiddelde genomen.

66. We hebben in de figuur alleen het gemiddelde percentage politiemensen aangegeven dat bij de laatst gevolgde vervolgopleiding een (gedeeltelijke) zelfmelder is geweest indien er minimaal 20 politiemensen het desbetreffende persoonlijkheidskenmerk hebben aangegeven. Daardoor zijn in Figuur C.2 niet alle scores op de $\mathrm{x}$-as opgenomen. 
om nieuwe dingen te leren. Hoe leuker zij dit vinden, hoe groter hun verwachting om binnen vijf jaar een vervolgopleiding te gaan volgen. In Panel (c) zien we de mate waarin politiemensen zichzelf doelen stellen voor de toekomst en in hoeverre zij een duidelijk beeld hebben van hun toekomstige loopbaan. Er blijkt veel heterogeniteit te zijn in de mate waarin dit van toepassing is op politiemensen. Bovendien laat Panel (c) zien dat er een positieve significante relatie is tussen dit derde persoonlijkheidskenmerk en de verwachting met betrekking tot het volgen van een vervolgopleiding de komende vijf jaar.

\section{Figuur C.2}

Persoonlijkheidskenmerken en de verwachting met betrekking tot deelname aan vervolgopleidingen
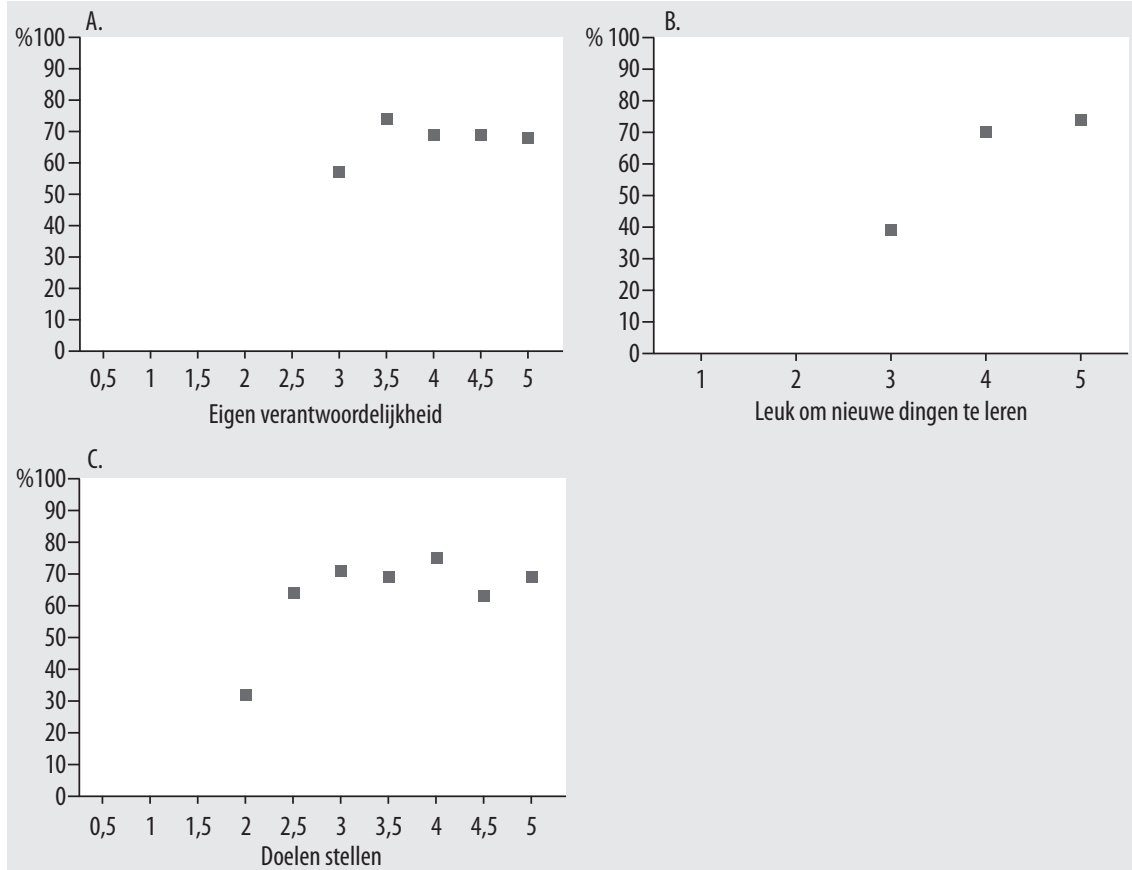

Bron: ROA enquête onder politiemensen 


\section{Bijlage D \\ Gesprekspartners}

In het kader van dit onderzoek hebben wij gesproken met personen uit de volgende organisaties: het programma HRM en Onderwijs van het Ministerie van Veiligheid en Justitie, de Inspectie VenJ, de Politieacademie, de Politieonderwijsraad (POR), de afdeling HRM van de Nationale Politie, de P\&O afdeling van een eenheid, politiemensen van verschillende eenheden, rangen en functies, het Ministerie van Onderwijs en externe deskundigen uit de sectoren zorg, transport, middelbaar onderwijs en hoger onderwijs.

Wij willen alle gesprekspartners van de interviews en de focusgroep danken voor hun medewerking aan het onderzoek.

Gesprekspartners

Dhr. W.M. van Andel, LLM (Wout)

Mevr. $\quad$ S.C.C. Appels-Verhulst (Saskia)

Dhr. M.V. Boerman (Michel)

Mevr. ir. M. Bronstring (Manon)

Mevr. prof. dr. M.C.J. Caniëls (Marjolein)

Mevr. drs. $\quad$ E. de Heus (Erica)

Mevr. drs. M.J.M. Janssen (Marga)

Dhr. $\quad$ P. Joosten (Peter)

Mevr. drs. O.E. Kramers (Olivia)

Dhr. F. Leijnse

Dhr. R. Lutgendorf (René)

Mevr. dr. $\quad$ B.G. Marsman (Bea)

Dhr. dr. J.B.A. Prins (Jan)

Dhr. J.H. Reuvers, MBA (Herman)

Dhr. drs. K. Sueters (Koen)

Mevr. drs. $\quad$ M. Vaessen (Margriet)

Mevr. $\quad$ E.R.M. Verhoef (Els)

Dhr. drs. drs. B.T.M. Verlaan (Bernard)

Mevr. $\quad$ E.S.W. van Vlijmen, MCI (Eefje)

Dhr. $\quad$ E. van der Worm (Ed) 



\section{Bijlage $E$ \\ Itemlijst interviews}

[Uitleg van het onderzoek en gehanteerde definities]

Kunt u een korte omschrijving geven van uw functie?

\section{Context}

- Een reorganisatie zo ingrijpend als de komst van de Nationale Politie brengt altijd spanningen met zich mee. Wat zijn de meest precaire spanningen waarvan we op de hoogte moeten zijn?

- Welke gevolgen van deze reorganisatie voorziet u voor de vraag naar politieonderwijs vanuit zowel korpsen als individuele medewerkers?

- Waarvan moeten we absoluut op de hoogte zijn als we spreken met vertegenwoordigers van diverse belanghebbende partijen?

\section{Het aanbod van politieonderwijs}

- Met welke kwalificaties van het regulier onderwijs zijn de kwalificaties van de post initiële opleidingen van de Politieacademie te vergelijken?

- Naar welk type politieopleidingen is de meeste vraag, en waarom?

- Hoe komt het aanbod van opleidingen aan de Politieacademie tot stand?

- Wat is de waarde van de post initiële politieopleidingen voor andere organisaties dan de Politie?

\section{(gedeeltelijk) Zelfmelden}

De rol van leidinggevenden

- Welke rol spelen leidinggevenden bij de politie in de huidige situatie bij het aanmelden van politiemensen voor het volgen van een vervolgopleiding?

- Wat vindt u van de huidige rol van leidinggevenden bij het aanmelden van politiemensen voor het volgen van een vervolgopleiding? 
- In hoeverre denkt u dat deze rol van leidinggevenden zal veranderen na de reorganisatie?

\section{Zelfmelden tot nu toe}

- Stel, een politiemedewerker wil vervolgonderwijs gaan volgen (uit eigen initiatief, niet per definitie bij de Politieacademie). Kunt $\mathrm{u}$ omschrijven hoe het proces doorgaans verloopt van het moment dat de politiemedewerker dat idee heeft, tot het moment dat hij/zij daadwerkelijk het gekozen onderwijs volgt?

- Zijn er politiemensen die nu al op eigen initiatief, kosten en/of in de eigen tijd onderwijs bij de Politieacademie of andere onderwijsinstellingen volgen?

\section{Zelfmelden in de toekomst}

- Wat zouden mogelijke prikkels zijn om politiemensen zelf het initiatief te laten nemen voor het volgen van een vervolgopleiding?

- Wat zouden mogelijke prikkels zijn om politiemensen een vervolgopleiding geheel of gedeeltelijk in de eigen tijd te laten volgen?

- Wat zouden mogelijke prikkels zijn om politiemensen zelf een financiële bijdrage te leveren aan hun vervolgopleiding?

- Stel dat uw leidinggevende tegen u zegt dat u in 2013 zo veel of weinig postinitiële opleidingen mag volgen als u wilt, maar dat u van één postinitiële opleiding zelf het cursusgeld moet betalen en de opleiding in uw eigen tijd moet volgen - dus vrij nemen als je les hebt of huiswerk moet maken. Welke opleiding (welk type) zou u kiezen om zelf in te investeren, en waarom?

* En als de Politie het cursusgeld van die ene opleiding zou betalen, maar $\mathrm{u}$ moet het nog wel in uw eigen tijd volgen. Welke opleiding zou u dan kiezen, en waarom?

* En als u zelf het cursusgeld zou moeten betalen, maar u krijgt wel doorbetaald als u les hebt? Welke opleiding zou u dan kiezen, en waarom?

\section{De mogelijkheden en belemmeringen van het flexibiliseren van het post initiële politieonderwijs}

- Wat vindt $\mathrm{u}$ van het initiatief om het anbod van politieonderwijs meer te flexibiliseren?

- Wat zijn risico's en mogelijkheden van flexibilisering van het politieonderwijs?

- In welke mate kan het verruimen van de mogelijkheden om politieonderwijs te volgen, een bijdrage leveren aan de kwaliteitsverhoging van het politieonderwijs?

- In hoeverre kan de kwaliteit van het politieonderwijs worden geborgd indien de politieopleidingen steeds meer flexibel en modulair worden aangeboden, en wat is de rol van certificering van modules hierin? 
- Welke gevolgen hebben nieuwe onderwijsvormen als e-learning, profchecks, kortdurende opleidingen, miniconferenties en -trainingen voor de kwaliteit van het politieonderwijs?

- Wat zijn volgens u de belangrijkste gevolgen van het voor zij-instromers toegankelijker maken van onderwijs aan de Politieacademie?

Slot

- Wat mogen we niet vergeten om te vragen in de enquêtes onder politiemedewerkers?

- Zijn er andere zaken waar we rekening mee moeten houden bij het opstellen van de enquête? 



\section{Bijlage $F$ \\ Itemlijst focusgroep}

Discussie over de resultaten van het kwantitatief onderzoek

Onderwerpen:

Respons op de vragenlijst, samenstelling steekproef

Opleidingsdeelname tot nu toe

- Vervolgopleidingsdeelname tot nu toe

* Naar leeftijd

* Naar rang

* Naar domein

* Naar type opleiding

- Reden voor de gevolgde vervolgopleiding

- Wie betaalde de vervolgopleiding?

- In wiens tijd werd de opleiding gevolgd?

- Wie nam het initiatief om de opleiding te volgen?

\section{$H R$ beleid tot nu toe}

- Visie van leidinggevenden

- Speerpunten van leidinggevenden

- Waardering van medewerkers voor HR beleid

\section{Potentiële zelfmelders}

- Verwachte toekomstige opleidingsdeelname

* Naar leeftijd

* Naar rang

- Bereidheid tot eigen bijdrage in tijd, geld, initiatief

- Waarom niet aan een vervolgopleiding deelnemen?

\section{Van potentiële naar daadwerkelijke zelfmelders}

- Prikkels voor het volgen van een vervolgopleiding

\section{Discussie:}

Onder de aanname dat opleidingsbudgetten (verder) onder druk komen te staan, hoe kan met de beschikbare middelen creatief aan opleiden worden gedaan waarbij rekening gehouden wordt met de wens voor meer zelfmelders in de toekomst? 



\section{Summary}

It has always been common practice in the police force that police officers are signed up for training courses at the Police Academy by their superiors, that courses are paid for by the force, and courses are taken during working hours. As a result, it is practically out of the question that police officers take the initiative (as a 'self-enroller') for a course at the Police Academy, investing their own time and/or money. In the consultations between the Director of Police and the police unions at the end of 2OII, however, the need was expressed to increase the number of 'self-enrollers'. The term 'self-enrollers' refers to police officers who partly or fully at their own initiative and/ or partly or fully during their own time and/or with their own money, take a training course. As opportunities for self-enrollers have always been limited, it is unknown what factors would encourage police officers to take a training course as 'self-enroller'. Neither is it known how flexibilisation of police training, defined as offering variations in the organisation and setup of the training programme, could play a role in the process of getting more self-enrollers. This leads to the following research question:

How can police officers be encouraged or facilitated to render them more inclined in the future to self-enroll for training courses - partly or fully at their own initiative, and partly or fully with the investment of their own time andlor money - and could flexibilisation of police training play a role in this process?

This summary presents the main findings of the study.

\section{Research Approach}

For this study, use was made of a combination of quantitative and qualitative research: a literature study, a survey among police officers, interviews with parties involved in police training, interviews with police officers, interviews with 'hands-on' experts in the field of education in fields outside the police force, and a focus group of stakeholders. The survey constitutes the principal part of the study. The survey was distributed among 2,4II police officers, I,O44 of whom completed the questionnaire in part or in full. The response rate of the survey is therefore $43 \%$. 


\section{Incentives to Increase the Number of Self-enrollers}

The two incentives that have the greatest effect on the willingness to 'self-enroll' for training are of a financial nature. For a large majority of respondents, 'A higher salary' and 'being allowed to take a paid course' would be reasons for greater willingness to self-enroll for courses in the future. Even if the possibility were given of taking a training course during working hours, the willingness to partly or fully pay for courses and to take the initiative would increase among half of the police officers. Being allowed to take a training course of their choice or the guarantee of obtaining a position matching the training level, also has a positive effect on the willingness to selfenroll for approximately half of the respondents. Offering flexible types of training, such as modular courses and time- and place-independent learning, have a relatively less stimulating effect on the willingness to partly or fully self-enroll for training, but nevertheless increases the willingness of approximately a third of the respondents.

The results of this study show that of the three facets of self-enrolling, the willingness to take the initiative is the one that can be influenced most. On the other hand, it appears slightly less easy to encourage police officers to do training in their own time. It is even more difficult to influence the willingness to make a financial contribution to the cost of the training.

\section{Feasibility of Incentives}

\section{Training leads to a higher salary in current job/training course is paid for by employer}

One of the incentives that increases the willingness of most police officers to selfenroll for training, is the employer paying for the course. However, this incentive is at odds with one of the three facets of self-enrolling explored in this study: participants fully or partly paying for the training course. If, on the basis of various interviews and the focus group, we start from the real situation of constraints on training budgets, then financial incentives such as a course being paid for by the employer or higher salaries in one's current job, are incompatible with this reality. This implies that the implementation of the incentives 'higher salary in current job' and 'training course is paid for' requires an unrealistic increase of financial resources within the units. The immediate conclusion is therefore that these two incentives are not in line with current police policies.

At the same time, the willingness to take the initiative and/or invest time in a training course increases for sixty per cent of the police officers who completed the survey if the employer were to pay for the course. This appears to offer the possibility to give a major boost to self-enrolling on the basis of the facets of own initiative and time. In fact, this is a trade-off scenario that has been successfully applied in a large health care institute in the Randstad. The institute concluded that it would cost much more 
to take employees out of the work schedule for training than to pay for the training course itself. For this reason, the institute chose to concentrate on increasing the willingness of staff to take training courses in their own time. Only if employees clearly benefit from the training course, they are asked to make a financial contribution. Such training courses greatly improve the general labour market perspectives for the employee concerned, also outside the institute itself.

\section{Taking a training course during working hours}

Taking a training course during working hours is an incentive that would also create a greater willingness among relatively a high percentage of police officers in this survey to show initiative in the future and/or pay all or part of the training course. However, even though this incentive appears to work with respect to those two facets of selfenrolling, it achieves the opposite of what this study explores: that police officers take more training in their own time. At best, this incentive could be used to establish a trade-off, in which a considerable number of police officers would be prepared to take the initiative and pay all or part of the training costs, but then on condition that the course can be taken during working hours.

\section{Employees can take a course of their choice}

The study shows that approximately half of all police executives indicate that they have not refused a single training request in the previous three years. This implies that these executives do not obstruct the choices of their employees with regard to training courses, which is a positive aspect for the incentive 'employees can take a course of their choice'. Nevertheless, the required approval of their superiors in itself could interfere with the sense of freedom of choice. Optimal introduction of the 'freedom of choice' incentive would therefore imply that intervention of superiors is no longer required for registration for certain training courses. This does not, however, answer the question who pays for the course and in whose time this course is taken. For approximately half of the police officers, the freedom of choice incentive has a positive effect both on the willingness to spend their own time on the course and on the willingness to invest their own money in the course. The 'freedom of choice' incentive therefore appears potentially successful in order to create more self-enrollers. It would be necessary in that case to ensure that courses are flexible enough to enable employees to take them in their own time.

\section{Guarantee of a job matching the acquired training level}

Interviews have shown that training courses to date were frequently linked to promotion or a change of jobs. The wish to have more police officers in the future take the initiative and pay for their training courses, is also prompted by the idea that police officers would then make their choices for such courses on more intrinsic grounds. It is considered increasingly less desirable that the motivation for taking a training 
course is extrinsically driven. The incentive of a guaranteed job matching the training level therefore seems incompatible with the shift from a human resources policy based on the legal position to a development-oriented policy.

\section{The training course can be taken in modules/learning is time- and place-independent}

Various interviews, meetings and the focus group of policy experts have shown that the Police Academy is positively inclined towards offering more modular courses and applying e-learning. E-learning makes courses time- and place-independent. Moreover, these incentives probably affect budgets the least. The example from the health care sector (see page 76) also shows that, by making use of e-learning for knowledge components of the courses, employees need not be given leave. This limits staffing problems.

\section{Final Conclusions}

Compared to the other incentives, the incentives provided by the flexibilisation of police training, modular education and time- and place-independent learning, appear to encourage relatively few police officers to be more willing to take the initiative or to invest time or money. Nevertheless, the potential of such incentives must not be underestimated. After all, the proper reference framework is not the effectiveness of the other, largely extrinsic, financial incentives. The reference framework is the existing situation, in which training courses are usually initiated and paid for by the police force and can be taken during working hours. This is the 'ist' situation in which the study was done and to which the organisation and its employees are used. The first conclusion is:

Because of the existing policy on training courses, police officers are used to take part in such courses for extrinsic reasons. The 'soll' situation, in which more police officers take part in courses partly or fully as self-enroller, is far removed from the situation that police officers and their organisation have been used to until now.

Using this 'ist' situation as a point of departure, it is unlikely that new incentives can be found that would suddenly motivate a majority of the police officers to invest time in a course or pay for such a course. In that sense, it is a confirmation of the degree to which those involved are used to the current situation that the extrinsically motivating incentives based on time and money are effective for so many of the police officers taking part in the survey. In this light, the second conclusion is very positive and promising: 
Flexible education, including offering more modular courses and time-and place-independent learning, increases the willingness to self-enroll, partly or fully, for future training courses for no less than a third of the police officers.

This shows that, in spite of their being used to the current extrinsically motivated training policy, a considerable number of police officers already responds to intrinsic incentives.

The study also shows that trade-offs can be established between various facets of selfenrolling. It would be very ambitious and, considering the research outcomes, not very realistic to want to go from a situation without self-enrollers to a situation with a large number of police officers who both take the initiative for training courses entirely by themselves and pay for these courses themselves, as well as doing the courses in their own time. It does appear to be possible, as a first step in this direction, to find more police officers prepared to show more initiative and invest time in a training course, provided it is paid for by the employer. More than $60 \%$ of all police officers would then be prepared to do a course in their own time or at their own initiative. This trade-off - the course is paid for by the employer, but done in the employee's own time - is already effective in the health care sector, as shown by the example on page 94. The third conclusion is therefore:

\section{Self-enrolling can be encouraged in more than $60 \%$ of the police officers with regard to the facets of 'own initiative' andlor 'own time', as long as the police force pays for the course. This can be complementary to stimulating self-enrol- ling through modular and time-and place-independent learning.}

The study therefore shows that various incentives can be used to encourage police officers to take training courses in the future as self-enroller. Flexible education, such as modular courses and time- and place-independent learning, constitute the two incentives that appear to have the least effect on budgets and at the same time appeal to the intrinsic motivation of police officers.

Police executives already appear to be ready to a reasonable degree for a situation in which more police officers self-enroll for training courses. This is indicated by various results. Chapter 2 describes that approximately half of all superiors indicated that they have not refused a single training request in the previous three years. If a training request was refused, this was usually for budgetary reasons, and less often for contentrelated reasons. This suggests an open attitude towards requests from personnel. Chapter 2 also shows that executives believe that the initiative for most types of training courses should be taken significantly more often by employees than by superiors. This indicates that executives no longer believe that only they should determine who takes what course and when. Nevertheless, approximately half of the employees still feels insufficiently supported by their superiors when it comes to career opportunities and commitments in this field. This leads to the fourth conclusion: 
All in all, executives appear to have the right disposition to a reasonable degree to handle future self-enrollers, but this is not sufficiently reflected in the practical experience of employees.

However much willingness to take the initiative and to invest time and money in the future can be achieved among police officers, this will have to be widely supported at executive level. Interviews with educationalists both from the health care and the education sectors, show that it is crucial that the idea that training and education are something that employees can take the initiative for, must be propagated as well as applied in a concrete, consistent and top-down way. 